
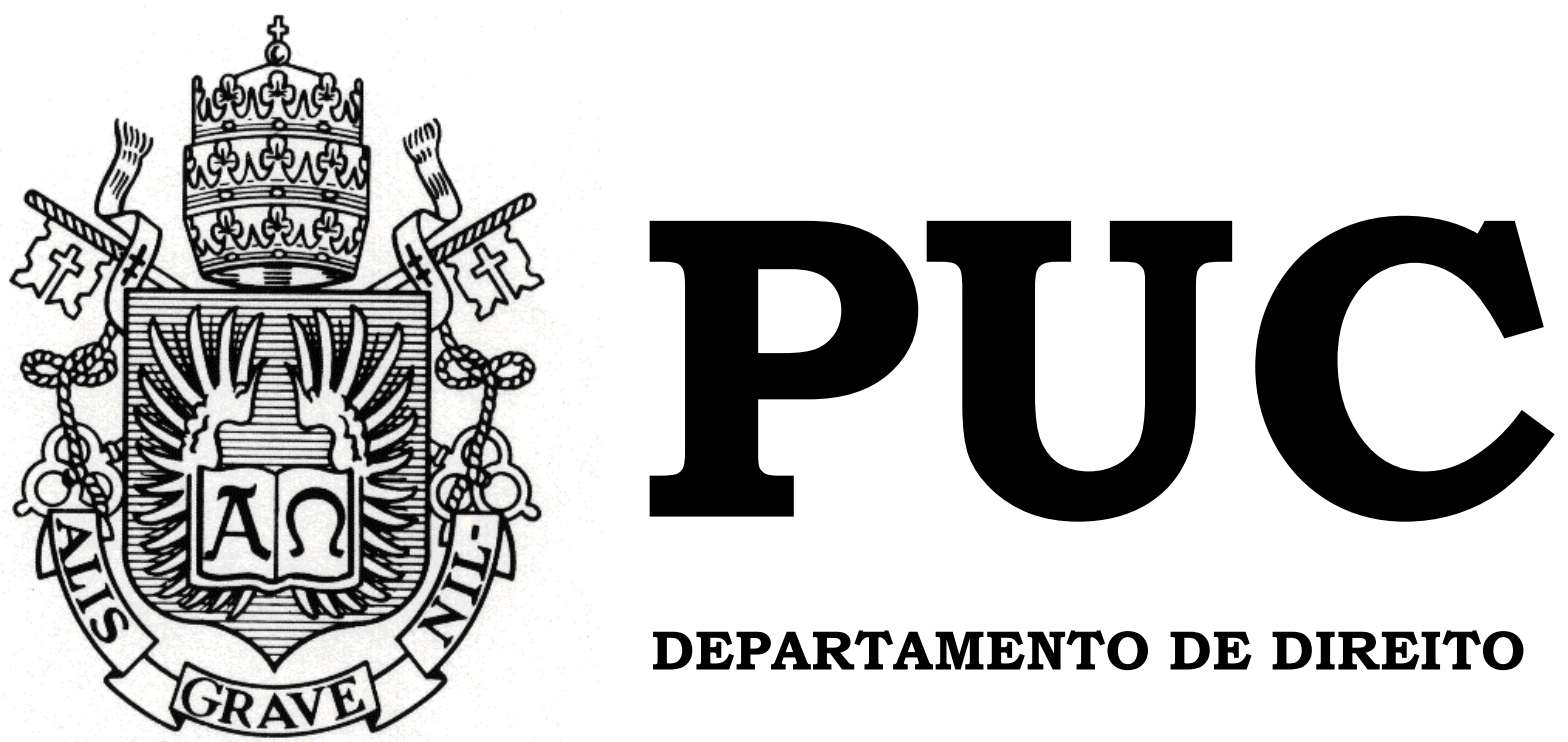

DEPARTAMENTO DE DIREITO

\title{
O DIREITO FUNDAMENTAL À CULTURA: MECANISMOS E POLÍTICAS PÚBLICAS PARA SUA EFETIVAÇÃO, TUTELA E DEMOCRATIZAÇÃO
}

por

FELIPE MONTEIRO DOS SANTOS

ORIENTADORA: Regina Coeli Lisbôa Soares 2011.2

PONTIFÍCIA UNIVERSIDADE CATÓLICA DO RIO DE JANEIRO

RUA MARQUÊS DE SÃO VICENTE, 225 - CEP 22453-900

RIO DE JANEIRO - BRASIL 


\section{O DIREITO FUNDAMENTAL À CULTURA: MECANISMOS E POLÍTICAS PÚBLICAS PARA SUA EFETIVAÇÃO, TUTELA E DEMOCRATIZAÇÃO.}

por

FELIPE MONTEIRO DOS SANTOS

Monografia apresentada ao Separtamento de Direito da Pontificia Universidade Católica do Rio de Janeiro (PUC-Rio) para a obtenção do Título de Bacharel em Direito.

Orientador(a): Regina Coeli Lisbôa Soares 
Ao meu avô e melhor amigo, Lourenço (in memoriam), um ser humano inigualável a quem devo eterna gratidão. 


\section{Agradecimentos.}

À minha orientadora Prof. a Regina Soares, pessoa muito querida que, através de seus conselhos, indicações e debates, ajudou-me a construir um rumo a ser trilhado por esta monografia cujo tema é tão amplo e rico;

Ao meu pai Sylvio, por seu grande interesse na monografia e por todo apoio dado durante sua realização; à minha avó Dulce, pessoa cujo nome reflete sua personalidade;

Ao Prof. Francisco Humberto Cunha Filho, pela remessa de suas obras que foram de suma importância para o amadurecimento e realização do presente trabalho; à Ana Aragão por suas indicações bibliográficas;

Ao meu caro amigo Prof. Pedro Marcos Nunes Barbosa, quem me possibilitou ter, através de nosso dia a dia profissional no campo de outro direito fundamental - o direito à saúde -, uma nova visão acerca do Direito e sua capacidade de transformar a realidade;

Às amizades que criei e/ou consolidei no âmbito da PUC-Rio durante os últimos cinco anos e meio: Patricia Acacia, Guilherme Souto, Guilherme Santos, Karina Pinhão, Felipe Moraes, Marina Carneiro, Pedro Antonio Assumpção, Emiliano Veiga, Felipe Pires, Felipe Duque-Estrada, Bernardo Silva, Katherine Chediak, Emiliano Gomide, Magno Mendes e Bernardo Secchin;

A Tadeu Salgado, Michelli Giovanelli, Richard Ruszynski, Livia Simas, Thiago Castro, Pedro Maia, Thiago Saldanha, amigos que me permitiram nunca cortar meu vínculo com a Faculdade de Produção Cultural da Universidade Federal Fluminense (UFF) desde minha saída em 2006;

À Monica Visco, por ter me dado os alicerces para que eu sempre continuasse na luta; a todos os funcionários da Divisão de Bibliotecas e Documentação da PUC-Rio; e

Por fim, os meus agradecimentos especiais à minha mãe Célia, quem sempre me apoiou em todas as decisões ao longo da minha vida e revisou esta monografia com o interesse, a paciência e a compreensão que lhe são característicos. 


\section{RESUMO}

O direito à cultura, tradicionalmente caracterizado como um direito humano de segunda geração, recebeu pela Constituição Federal de 1988 o status de direito fundamental. Ao tratar especificamente do tema em seus artigos 215 e 216, a Constituição estabeleceu normas programáticas de eficácia limitada que deverão ser efetivadas através de uma prestação positiva do Estado. Desta forma, para efetivar e tutelar o Direito Fundamental à Cultura vislumbra-se a necessidade do Estado elaborar políticas públicas culturais em conjunto com a Sociedade Civil. $\mathrm{O}$ presente trabalho analisa o histórico das políticas públicas culturais brasileiras entre os anos 1930 e 2010, como também os principais instrumentos por elas criados para o fomento e custeio à produção cultural - o Programa Nacional de Apoio à Cultura (PRONAC), instituído pela Lei no 8.313/1991, também conhecida como Lei Rouanet, e a Lei no 8.685/1993, também conhecida como a Lei do Audiovisual -; para a tutela do Patrimônio Cultural Brasileiro - Tombamento, Inventário, Vigilância, Registro, Ação Popular e Ação Civil Pública-; e para a democratização cultural - o Plano Nacional de Cultura, o Programa Cultura Viva, o Sistema Nacional de Cultura, a Reforma da Lei Rouanet e demais Propostas de Emenda à Constituição (PECs) e Projetos de Lei (PLs) que versam sobre a matéria e que ainda se encontravam em trâmite no Congresso Nacional até outubro de 2011.

\section{Palavras-chave}

Direito Constitucional, Direitos Humanos, Direito à Cultura, Direitos Culturais, Políticas Culturais, Lei no 8.313./1991 (Lei Rouanet), Lei no 8.685/1993 (Lei do Audiovisual), Decreto-Lei no 25/1937, Tutela do Patrimônio Cultural Brasileiro, Democratização Cultural, Plano Nacional de Cultura, Sistema Nacional de Cultura, Cultura Viva. 


\section{SUMÁRIO}

1. Introdução.

2. Direitos Culturais como Direitos Humanos e o Direito Fundamental à Cultura na Constituição Federal de 1988.

2.1. Histórico, Características e a Proteção no Plano Internacional dos Direitos Humanos Culturais.

2.1.1. O Histórico dos Direitos Humanos e seus Diferentes Momentos. 14

2.1.2. A Proteção dos Direitos Culturais no Plano Internacional.

2.2. O Direito Fundamental à Cultura na Constituição Federal de 1988.

2.2.1. Características Gerais dos Direitos Fundamentais na Constituição Federal de 1988.

2.2.2. A "Constituição Cultural": O Direito Fundamental à Cultura na Constituição Federal de 1988 e a Eficácia de suas Normas. 33

3. Políticas Públicas Culturais no Brasil. Mecanismos para a Efetivação do Direito Fundamental à Cultura e Tutela do Patrimônio Cultural Brasileiro.

3.1. Por uma Definição de Política Cultural e seu Histórico no Brasil Desde os Anos 1930.

3.1.1. O que é Política Cultural.

3.1.2. As Políticas Culturais no Brasil: da Era Vargas ao Mandato de Fernando Henrique Cardoso.

3.2. A Efetivação do Direito Fundamental à Cultura.

3.2.1. Mecanismos para o Fomento e Custeio da Produção Cultural. ............... 60

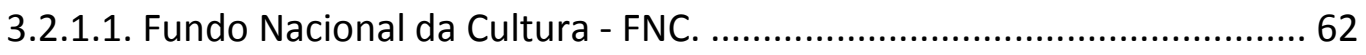

3.2.1.2. Fundos de Investimento Cultural e Artístico - FICARTs. ..................... 65

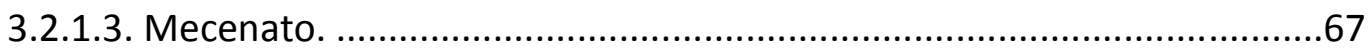

3.2.1.4. Lei do Audiovisual. ........................................................................... 70

3.2.2. Instrumentos para a Tutela do Patrimônio Cultural Brasileiro.

3.2.2.1. Tombamento. 
3.2.2.2. Inventário.

3.2.2.3. Vigilância.

3.2.2.4. Registro. 80

3.2.2.5. Ação Popular. 82

3.2.2.6. Ação Civil Pública. 83

4. Políticas Públicas Culturais no Governo Lula. A Reforma da Lei Rouanet e a Busca pela Democratização Cultural.

4.1. Políticas Culturais no Governo Lula e as Gestões de Gilberto Gil e Juca Ferreira no Ministério da Cultura. .88

4.1.1. O Programa Nacional de Cultura, Educação e Cidadania - Cultura Viva. ..91 4.1.2. O Plano Nacional de Cultura (PNC) e o Sistema Nacional de Cultura $(\mathrm{SNC})$

4.1.3. Propostas de Emendas à Constituição (PECs) e Projetos de Lei (PLs) que Versam Sobre Matéria Cultural. 98

4.2. A Reforma da Lei Rouanet e a Busca pela Democratização Cultural. .100

5. Conclusão. 106

6. Bibliografia. 110

7. Anexos. .120 
E se o que tanto busca só existe em tua límpida loucura -que importa?isso

exatamente isso

é o teu diamante mais puro!

(Mário Quintana) 


\section{Introdução.}

"Já que interpretei a amplitude que assumiu atualmente o debate sobre os direitos do homem como um sinal do progresso moral da humanidade, não será inoportuno repetir que esse crescimento moral não se mensura pelas palavras, mas pelos fatos. De boas intenções o inferno está cheio." ${ }^{1}$

A palavra cultura origina-se do verbo latino colere, cujos significados podem ser:

“1) Habitar, morar. 2)Cultivar (sentido físico e moral), praticar. 2) Daí: 3) Cuidar de,tratar de, ocupar-se de. 4) Proteger, querer bem a, agradar a . Por extensão: Honrar, cultuar, venerar, respeitar." ${ }^{2}$

Trata-se de uma expressão cujo sentido foi sendo reinterpretado ao longo da História do Homem, desde a Antiguidade até os dias atuais. É fruto de controvérsias e de inúmeras conceituações por parte das Ciências Humanas e Sociais, sobretudo da Antropologia, que a possui como seu tema de estudo central. Seu primeiro sentido, no período da Antiguidade Clássica, conforme leciona Marilena Chauí, foi:

"a intervenção deliberada e voluntária dos homens sobre a natureza de alguém para torná-la conforme aos valores de sua sociedade. Dessa perspectiva, a cultura era a moral (o sistema de mores ou de costumes de uma sociedade), a ética (a forma correta da conduta de alguém graças à modelagem de seu ethos natural pela educação) e a política (o conjunto de instituições humanas relativas ao poder e à arbitragem de conflitos pela lei)." ${ }^{3}$

Em um segundo momento, já entre o final do século XVIII e o início do século XIX, o antropólogo inglês Edward Tylor (1832 - 1917) condensa em uma só palavra duas expressões que estavam em voga em sua época: a palavra de origem germânica Kultur, que seria relacionada às características espirituais de uma determinada comunidade, janela pela qual seria expressa sua visão de mundo, e a palavra de origem francesa Civilization, relacionada às conquistas materiais e tecnológicas de um povo. Surge daí o vocábulo de origem inglesa Culture que, em seu sentido etnográfico, segundo as palavras do próprio antropólogo é:

\footnotetext{
${ }^{1}$ BOBBIO, Noberto. A Era dos Direitos. 19a Ed.. Rio de Janeiro: Elsevier, 1992. P. 64.

2 FARIA Ernesto. Dicionário Escolar Latino-Português. 4ạ Ed.. Rio de Janeiro: Ministério da Educação e Cultura, 1967. P.206.

${ }^{3}$ CHAUÍ, Marilena. Cidadania Cultural. São Paulo: Editora Fundação Perseu Abramo, 2006. P. 105.
} 
"este todo complexo que inclui conhecimentos, crenças, arte, moral, leis, costumes ou qualquer outra capacidade ou hábitos adquiridos pelo homem como membro de uma sociedade." 4

O meio social no qual está inserido o indivíduo exerce grande influência em sua formação. A cultura, portanto, era o resultado de um processo evolutivo e linear expressado por via das realizações de obras, feitos, ações, instituições (as artes, as ciências, a filosofia, os ofícios, a religião e o Estado) ${ }^{5}$, que gera uma situação em que o artificial, ou o "civilizado", se opõe à natureza humana, "nua" e ignorante ${ }^{6}$. Criou-se, assim, uma escala gradual de civilização que teve a Europa como paradigma do desenvolvimento mundial. Ressalta-se que o modelo da civilização europeia, que deveria ser exportado para o resto do mundo, foi o subsídio utilizado pelos próprios países europeus para justificar a prática do colonialismo nos continentes africano e asiático durante os séculos XIX e XX.

Somente a partir do final da primeira metade do século XX surgiu um novo conceito e olhar sobre a cultura pela Antropologia. O antropólogo alemão Franz Boas (1858-1949) realizou importantíssima contribuição ao permitir, através de seus estudos, a criação do conceito de relativismo cultural, ou particularismo histórico, ao afirmar que cada cultura deve ser analisada de forma particular, de acordo com "os seus próprios caminhos em função dos diferentes eventos históricos que enfrentou" 7. Outra grande contribuição foi dada pelo antropólogo americano Alfred Kroeber (18761960) ao mostrar que o Homem, apesar de possuir as mesmas funções e necessidades vitais, as realiza de maneiras diversas, de acordo com a cultura em que está inserido. De nada influi sua herança genética em seu comportamento, apenas seus padrões culturais. A partir da segunda metade do século $X X$, o termo adquire significado no campo das formas simbólicas, como atesta Marilena Chauí:

\footnotetext{
${ }^{4}$ TYLOR, Edward. Primitive Culture. Lenders, John Murray \& Co. [1958, Nova York, Harper Torchbooks] apud LARAIA, Roque de Barros. Cultura: Um Conceito Antropológico. 18ª. Ed.. Rio de Janeiro: Jorge Zahar Ed., 2005. P. 25.

${ }^{5}$ Cf. CHAUÍ, Marilena. Op. Cit. P. 106.

${ }^{6}$ Cf. CHAUÍ, Marilena. Cultura \& Democracia. 9ạ ed.. São Paulo: Cortez, 2001. P. 130.

${ }^{7}$ LARAIA, Roque de Barros. Op. Cit. P. 36.
} 
"cultura passa a ser entendida como criação coletiva da linguagem, da religião, dos instrumentos de trabalho, das formas de habitação, vestuário e culinária, das manifestações do lazer, da música, da dança, da pintura e da escultura, dos valores e das regras de conduta, dos sistemas de relações sociais, particularmente os sistemas de parentesco e as relações de poder." 8

Feita esta brevíssima síntese dos diversos significados do termo cultura, pois não cabe a esta monografia prolongar-se nas conceituações dos seus sentidos antropológicos, deve-se agora delinear o objeto do presente estudo: a cultura sob a ótica jurídica.

Certamente, esta não compartilha a definição antropológica de cultura, com base no fato desta ser ampla, ou seja, um emaranhado de signos criados, interpretados e valorados pelo ser humano dentro de um contexto social. Nesta esteira, o ensinamento de José Afonso da Silva:

"a Constituição não ampara a cultura na extensão de sua concepção antropológica, mas no sentido de um sistema de referência à identidade, à ação, à memória dos diferentes grupos formadores da sociedade brasileira (art. 216)." 9

Para fins do presente estudo, a definição de cultura para o Direito será a de Francisco Humberto Cunha Filho que, em importantíssima contribuição para o tema, consignou ser

"a produção humana juridicamente protegida, relacionada às artes, à memória coletiva e ao repasse de saberes, e vinculada ao ideal de aprimoramento, visando à dignidade da espécie como um todo, e de cada um dos indivíduos". ${ }^{10}$

Neste esteio, o direito à cultura será compreendido de forma a abranger o direito à memória cultural, à produção cultural e de acesso à cultura. ${ }^{11}$

\footnotetext{
${ }^{8}$ CHAUÍ, Marilena. Op. Cit., p. 131.

${ }^{9}$ SILVA, José Afonso da. Ordenação Constitucional da Cultura. São Paulo: Editora Malheiros. 2001. P. 35.

${ }^{10}$ CUNHA FILHO, Francisco Humberto. Cultura e Democracia na Constituição Federal de 1988. A Representação de interesses e sua aplicação ao programa nacional de Apoio à Cultura. Rio de Janeiro: Letra Legal, 2004. P. 49.

${ }^{11}$ Cf. OLIVIERI, Cristiane Garcia. Cultura Neoliberal: leis de incentivo como política pública de cultura. São Paulo: Escrituras Editora, 2004. P. 29.
} 
Trata-se de uma matéria carente de doutrina e possuidora de uma escassa bibliografia. É perceptível que grande parte dos juristas escreve sobre o tema en passant, seja por considerarem uma definição um tanto quanto óbvia, ou por entenderem que não cabe ao Direito defini-la, cabendo tal realização à Antropologia. Não se pode olvidar que o ensino dos direitos culturais na graduação dos cursos de Direito se dá de forma muito passageira. Quando ocorre, é geralmente distribuído entre as disciplinas de Direito Civil (direitos de autor), Direito Constitucional (direitos fundamentais), Direito Internacional Público (direitos humanos) e Direito Tributário (através do estudo do instituto da isenção fiscal, que é a base principal do funcionamento das leis de incentivo à cultura).

Embora considerados por Jesús Prieto de Pedro como parentes pobres dos direitos humanos ${ }^{12}$, os direitos culturais tiveram sua importância reconhecida a ponto do Constituinte Brasileiro (1986/1987) a eles dar o status de direitos fundamentais, mesmo não sendo tratados especificamente no catálogo do art. 5o da Constituição Federal de 1988. O Capítulo III do Título VIII da Carta Magna exemplifica esta afirmação ao criar expressamente normas constitucionais referentes à Educação, Cultura e Desporto, a despeito de não estarem somente ali localizados, conforme será demonstrado ao longo desta monografia.

O presente trabalho de caráter interdisciplinar busca traçar, a partir do tratamento constitucional dado à cultura e dos tratados internacionais assinados pelo Brasil referentes à matéria, um panorama geral sobre os atuais mecanismos e políticas públicas para o fomento, tutela e efetivação dos direitos culturais. Enfatiza-se que não visa a monografia, em momento algum, esgotar todas as suas garantias e possibilidades. A título exemplificativo, o anteprojeto de Lei que visa à reforma da Lei de Direitos Autorais (Lei no 9.610/1998), que foi fruto de extensivos debates promovidos desde as gestões dos Ministros da Cultura Gilberto Gil e Juca Ferreira, não será abordado, uma vez que, diante de sua complexidade e da ausência do texto final

\footnotetext{
${ }^{12}$ Cf. PEDRO, Jesús Prieto de. Direitos Culturais, O Filho Pródigo dos Direitos Humanos In: Observatório Itaú Cultural/OIC n. 11. (jan./abr. 2011). São Paulo: Itaú Cultural. 2011. P. 43.
} 
aprovado pelo Congresso Nacional até o fim da redação desta monografia, seria digno de um estudo mais aprofundado no campo do Direito Civil.

O primeiro capítulo tem como finalidade, partindo da conceituação e das particularidades que envolvem os Direitos Fundamentais, situar e analisar o Direito Fundamental à Cultura nos contextos constitucional e internacional. Aqui serão abordados a questão de sua eficácia normativa, como também o histórico dos Direitos Humanos, estudo que usualmente atribui aos direitos culturais a característica de ser um típico exemplo contido na lista de direitos humanos da segunda geração, a par dos direitos econômicos e sociais. Tese esta combatida pelo constitucionalista português Vasco Pereira da Silva ao argumentar que todas as divisões possuem direitos culturais nelas inclusos, conforme será exposto neste capítulo.

Diante da eficácia limitada das normas constitucionais no tocante aos Direitos Culturais, o segundo capítulo analisará o histórico das políticas públicas culturais entre a Era Vargas e o mandato de Fernando Henrique Cardoso, bem como a legislação infraconstitucional referente à sua efetivação no ordenamento jurídico brasileiro. Inclui-se neste rol mecanismos de natureza fiscal (o PRONAC - Programa Nacional de Apoio à Cultura, instituído pela Lei o 8.313/91, vulgo Lei Rouanet, e a Lei oㅗ 8.685/96, conhecida como a Lei do Audiovisual); de natureza processual (Ação Popular e Ação Civil Pública), e de natureza administrativa (Tombamento, Inventário, Registro e Vigilância).

Por fim, o terceiro capítulo consiste em uma descrição das Políticas Públicas Culturais durante o governo Lula. A gestão Gilberto Gil/Juca Ferreira foi considerada por produtores, gestores e profissionais da área cultural como um turning point, uma vez que o Ministério da Cultura passou a ter maior visibilidade e notoriedade diante do Poder Executivo Federal, embora até hoje a luta para que 1\% do total do Orçamento Geral da União, o ideal sugerido pela UNESCO, seja destinado à pasta ainda não tenha logrado êxito. Destacam-se aqui o Plano Nacional de Cultura, sancionado durante o término do governo Lula; o Sistema Nacional de Cultura; a bem sucedida experiência envolvendo o Programa Cultura Viva; a proposta de revisão da Lei Rouanet (tema que 
envolve extensivos debates promovidos pelo Ministério da Cultura e realizados pelo país); e as Propostas de Emenda Constitucional (PECS) e Projetos de Lei (PLs) que versam sobre a matéria cultural.

Diante da noção de que a efetivação do Direito Fundamental à Cultura contribui como fator de desenvolvimento, garantia de liberdade, exercício de cidadania, afirmação de uma identidade nacional, concretização dos princípios democráticos contidos na Carta Magna, e, sobretudo, respeito à dignidade da pessoa humana, revestindo-se assim de um caráter transversal, este estudo busca dar uma singela contribuição ao tema que, embora seja de extrema importância, infelizmente vem sendo pouco valorizado pelos juristas brasileiros desde a promulgação da Constituição Federal de 1988. 


\section{Direitos Culturais como Direitos Humanos e o Direito Fundamental à Cultura na Constituição Federal de 1988.}

"Uma cultura só pode afirmar as suas bases nacionais quando livre, e só é livre quando cada um não conhecer restrições ou ameaça ao seu modo de pensar e ao direito de expressá-lo, de realizá-lo artisticamente. Cultura nacional e democracia, assim, são problemas conjugados. E há imensas tarefas à nossa frente como, só para citar uma, a da integração de enormes parcelas da população na vida nacional, de que estão distanciadas enquanto mantidas na miséria e na ignorância, sua consequência inevitável. Temos um mundo a construir." ${ }^{13}$

\section{1 - Histórico, Características e a Proteção no Plano Internacional dos Direitos Humanos Culturais.}

\subsection{1 - O Histórico dos Direitos Humanos e seus Diferentes Momentos.}

A expressão "direitos do homem" (droits de l'homme) foi utilizada pela primeira vez na obra de Jean Jacques Rousseau denominada $O$ Contrato Social ${ }^{14}$, publicada pela primeira vez na França no ano de 1762. Outros autores franceses contemporâneos a Rousseau, como por exemplo, Baron D’Holbach, François Raynal e Louis Sebastién Mercier, também utilizaram o mesmo termo sem, no entanto, defini-lo. Estes autores consideravam os direitos do homem como autoevidentes, logo, desnecessária sua definição. Bastaria que um direito do homem fosse violado para que, então, fosse reconhecido diante do horror que provocaria. ${ }^{15}$

Para desenvolver o primeiro subitem do primeiro capítulo, torna-se necessário compreender o contexto europeu em que os autores supracitados encontravam-se, e, também, o norte-americano, palco de importantes acontecimentos referentes à

\footnotetext{
${ }^{13}$ WERNECK SODRÉ, Nelson. A Luta Pela Cultura. Rio de Janeiro: Editora Bertrand Brasil, 1990. P. 185

14 "A referida expressão aparece apenas uma vez na obra, que também se utiliza de expressões como "direitos da humanidade", "direitos do cidadão" e "direitos da soberania", no capítulo VIII do Livro IV (Da Religião Civil): "Afora a única nação que a segue, todos os demais para ela são infiéis estrangeiros $e$ bárbaros; ela só leva os deveres e os direitos do homem até onde vão seus altares. Foram assim as religiões dos primeiros povos, às quais se pode dar o nome de direito divino civil ou positivo". (grifei) (ROUSSEAU, Jean Jacques. O Contrato Social. Coleção Os Pensadores, vol. 1. Trad. Lourdes Santos Machado. São Paulo: Ed. Nova Cultural, 1999. P. 237).

${ }^{15}$ Cf. HUNT, Lynn. A Invenção dos Direitos Humanos: uma história. Trad. Rosaura Eischenberg. São Paulo: Companhia das Letras, 2009. P. 24 e 25.
} 
construção dos direitos humanos. Os ideais do movimento de caráter político e cultural denominado Iluminismo a par do Liberalismo Clássico, cujos maiores expoentes foram Rousseau, Locke e Montesquieu, espalharam-se pela Europa e Estados Unidos nos século XVIII. Ideais burgueses estes que gerariam profundas alterações nas concepções acerca das antigas estruturas do poder conhecido como Antigo Regime. Estas eram as principais críticas realizadas no campo do Direito à sociedade no final do século XVIII:

"a desigualdade diante da lei, que era mantida pelo sistema político dos 'estados', com seus privilégios fiscais para as ordens da nobreza e do clero e o acesso limitado aos cargos públicos; as limitações impostas às pessoas e às propriedades; a servidão; a exclusão da participação popular nos assuntos públicos, em contraposição à predominância da Igreja nos assuntos públicos; a intolerância religiosa; a desumanidade do direito penal, que infligia penas capitais e horríveis castigos corporais e mutilações; o processo penal, que ainda utilizava a tortura como método de investigação." 16

Com o desenvolvimento e a divulgação pelos pensadores europeus da ideologia liberal que continha novas concepções de individualidade, propriedade, igualdade, liberdade e do governo, que era baseada em uma forte crítica ao modelo do absolutismo monárquico, até então fundamentado na Teoria do Direito Divino dos Reis, junto com o amadurecimento da noção de autonomia da sociedade perante o Estado, era eminente que uma ruptura estaria por vir. Leia-se que, estava em jogo, portanto, uma luta pela conquista de direitos civis e políticos, que, se garantidos através de um texto constitucional, obrigaria o Estado a interferir e agir minimamente, afastando-se, desta forma, seus abusos e excessos.

O primeiro documento formal a consignar os direitos humanos foi a Declaração de Direitos do Bom Povo da Virgínia, de 12 de junho de 1776. Esta declaração reconhece a existência de direitos naturais ao Homem ao proclamar, seguindo um viés universalista, que "todos os homens são por natureza igualmente livres $e$ independentes e tem certos direitos inerentes", que seriam "a fruição da vida e da

\footnotetext{
${ }^{16}$ CAENEGEM, R.C. van. "Iluminismo, Direito Natural e os Códigos Modernos: da Metade do Século XVIII ao Início do Século XIX." In: Uma Introdução Histórica ao Direito Privado. São Paulo: Martins Fontes, 1995. P. 117-118 apud BENVENUTO LIMA JR., Jayme. Os Direitos Econômicos, Sociais e Culturais. Rio de Janeiro: Ed. Renovar, 2001. P. 14.
} 
liberdade, com os meios de adquirir e possuir propriedades e de buscar e obter felicidade e segurança." A historiadora norte-americana Lynn Hunt complementa:

"Ainda mais importante, a Declaração da Virgínia passava a oferecer uma lista de direitos específicos, como a liberdade de imprensa e a liberdade de opinião religiosa: ela ajudou a estabelecer o modelo não só para a Declaração da Independência, mas também a definitiva Bill of Rights da Constituição dos Estados Unidos. Na Primavera de 1776, declarar a independência - e declarar os direitos universais em vez de britânicos tinha adquirido momentum nos círculos políticos." ${ }^{17}$

A referida Constituição Estadunidense foi promulgada em 17 de setembro de 1787, porém sua primeira versão não continha uma declaração de direitos fundamentais do homem. Foi somente através de dez emendas constitucionais da Filadélfia que, ao serem aprovadas em 1791, criou-se a Bill of Rights americana. Esta, por sua vez, constituiu direitos como liberdade de religião e culto, de imprensa, de petição, direito à posse de armas e ao voto, garantia à propriedade, ao devido processo legal, à inviolabilidade da pessoa, da casa, de papéis e objetos, dentre outros.

Conforme visto acima, a ideia do Estado Liberal foi amadurecendo ao longo do século XVIII. No final da década de 1780, o Estado Francês encontrava-se em uma crise sem precedentes: seu apoio dado à Guerra da Independência Americana foi o principal fator que quase o levou à falência. O Rei Luis XVI, diante de uma extrema urgência, cedeu à pressão da sociedade, sobretudo do setor burguês, e convocou os Estados Gerais, em 1788. A abertura oficial se deu em 1789, e logo após, os deputados do Terceiro Estado (o povo, e nele incluída a burguesia) declararam-se, de modo unilateral, membros de uma Assembleia Constituinte, que promulgou, em 27 de agosto de 1789, a Declaração dos Direitos do Homem e do Cidadão. Os direitos nela consagrados seguem o sentido dos direitos contidos na Declaração da Virgínia, embora o que a torne marcante seja sua característica universalizante ${ }^{18}$ : liberdade, igualdade em direitos, garantia à propriedade, liberdade religiosa, de opinião, vedação de ordens arbitrárias por parte do Estado, participação popular na elaboração das leis etc. Houve,

\footnotetext{
${ }^{17}$ HUNT,Lynn. Op. Cit. p. 121.

${ }^{18} \mathrm{O}$ art. 1으 da Declaração dos Direitos do Homem e do Cidadão consagrou que "os homens nascem livres e iguais em direitos. As distinções sociais só podem ser baseadas na utilidade comum."
} 
assim, a consolidação da proteção aos direitos individuais, bem como a formação de uma nova postura que o Estado deveria adotar, consoante o art. 3ำ da Declaração: “O princípio de toda soberania reside essencialmente na nação. Nenhum corpo e nenhum indivíduo pode exercer uma autoridade que não emane expressamente da nação".

José Afonso da Silva sintetiza o entendimento ao afirmar que:

"O texto da Declaração de 1789 é de estilo lapidar, elegante, sintético, preciso, e escorreito, que, em dezessete artigos, proclama os princípios da liberdade, igualdade, da propriedade e das legalidades $e$ as garantias individuais liberais que ainda encontram nas declarações contemporâneas, salvas as liberdades de reunião e de associação que ela desconhecera, firmado que estava em uma rigorosa concepção individualista." 19

As constituições que surgiram durante todo o século XIX consolidaram os direitos humanos de cunho liberal-burguês, ou seja, os direitos civis e políticos, que garantiam a proteção do indivíduo perante o Estado, dada através de uma prestação negativa por parte deste.

Somente no início do século $\mathrm{XX}$, após propagação e advento da ideologia marxista, é que surge uma nova perspectiva dos direitos humanos: os direitos econômicos, sociais e culturais. Estes foram resultados de um redimensionamento dos direitos à propriedade e das garantias individuais com a finalidade de assegurar às classes excluídas do desenvolvimento direitos relativos ao trabalho, saúde, educação, cultura e previdência social. Houve uma necessidade de maior atuação do Estado através da ampliação de seus poderes. Portanto, ao contrário dos direitos civis e políticos, os direitos econômicos, sociais e culturais prezavam por uma prestação positiva do Estado.

Apesar de não reconhecer nenhum direito específico, o primeiro documento a conter uma visão socialista, fortemente influenciado pelas teses de Karl Marx, Friedrich Engels e Vladmir Lenin, foi a Declaração dos Direitos do Povo Trabalhador e Explorado, proclamada pelos bolcheviques em janeiro de 1918. Seu principal objetivo, de acordo

\footnotetext{
${ }^{19}$ SILVA, José Afonso da. Curso de Direito Constitucional Positivo. 34a Ed. São Paulo: Ed. Malheiros, 2011 P. 158.
} 
com o artigo 2, caput, era "abolir toda a exploração do homem pelo homem, suprimir por completo a divisão da sociedade em classes (...), estabelecer uma organização socialista da sociedade."

Em 5 de fevereiro de 1917 foi promulgada, dentro do contexto de uma revolução popular, a Constituição Mexicana. É considerada como a primeira carta a consagrar, de forma sistematizada, direitos sociais do Homem, pois, em seu artigo 123, que está em vigor até hoje, concede proteção ao trabalho e à previdência social. A mesma direção foi tomada pela Constituição de Weimar, promulgada na Alemanha em 11 de agosto de 1919. Embora presente em um contexto totalmente diferente ao mexicano, consagrou em sua segunda parte capítulos referentes a direitos da pessoa individual, da vida em comunidade (direitos da vida social), da religião e comunidades religiosas, da educação e escola e direitos econômicos.

O século XX presenciou duas guerras mundiais que, juntas, totalizaram cerca de 74 milhões de mortos. ${ }^{20}$ Os Estados perceberam que não poderiam ficar inertes. Seria necessário adotar uma nova postura de cooperação entre si para atingir uma finalidade: garantir a paz e a segurança internacional. A primeira tentativa foi a criação da Liga das Nações após o término da 1ạ Guerra Mundial, em 1920. Porém, fracassou, sobretudo devido à recusa de ratificação por parte dos Estados Unidos, bem como não foi capaz de conter o avanço do nazismo na Alemanha e fascismo na Itália nas décadas subsequentes.

Diante das atrocidades da 2a Guerra Mundial (1939-1945), os Aliados retomaram à ideia de criar uma nova Organização Mundial, que viria a tornar-se a Organização das Nações Unidas, fundada em 26 de junho de 1945. Nesta nova etapa dos direitos humanos, em que surge a preocupação dos Estados-membros em garantir sua universalização e evitar que ocorram novamente quaisquer atos de brutalidade, o indivíduo se torna o principal sujeito do Direito Internacional, conforme sustentado por Flávia Piovesan:

"No momento em que os seres humanos se tornam supérfluos e descartáveis, no momento em que vige a lógica da destruição, em que cruelmente se abole o valor da

${ }^{20}$ Cf. LYNN, Hunt. Op. cit. P. 202. 
pessoa humana, torna-se necessária a reconstrução dos direitos humanos, como paradigma ético capaz de restaurar a lógica do razoável. A barbárie do totalitarismo significou a ruptura do paradigma dos direitos humanos, por meio da negação do valor da pessoa humana como valor da fonte do direito. (...) Neste contexto, desenha-se o esforço ético a orientar a ordem internacional contemporânea. Se a Segunda Guerra significou a ruptura com os Direitos Humanos, o pós-guerra deveria significar sua reconstrução." 21

O principal marco desta nova concepção dos direitos humanos é a Declaração Universal dos Direitos Humanos, adotada em 10 de dezembro de 1948 por 48 Estados membros da ONU, apesar de oito abstinências. Seu objetivo maior reside na delineação "de uma ordem pública mundial fundada no respeito à dignidade humana, ao consagrar valores básicos universais" ${ }^{\prime 22}$, expresso na primeira frase de seu preâmbulo ${ }^{23}$, que a despeito de não prever um mecanismo de imposição, gera uma obrigação moral aos Países-membros para respeitá-los e efetivá-los.

Embora a clássica divisão entre gerações de direitos humanos seja criticada atualmente pela doutrina ${ }^{24}$, pode-se afirmar que estão contemplados na Declaração Universal dos Direitos Humanos com o mesmo grau de importância os direitos humanos de primeira geração (direitos liberais-burgueses, ou seja, direitos civis e políticos), e.g., liberdade de opinião e expressão, direito à propriedade e sua proteção, liberdade de pensamento, consciência e religião; de segunda geração (aqueles oriundos do discurso social da cidadania, ou seja, os direitos econômicos, sociais e

\footnotetext{
${ }^{21}$ PIOVESAN, Flávia. Direitos Humanos e o Direito Constitucional Internacional. 8a Edição. São Paulo: Ed. Saraiva 2007. P.118.

${ }^{22}$ Ibid. P. 137.

${ }^{23}$ O Preâmbulo da Declaração Universal dos Direitos Humanos assim inicia: "Visto que o reconhecimento da dignidade inerente a todos os membros da família humana e de seus direitos iguais e inalienáveis é o fundamento da liberdade, da justiça e da paz do mundo".

${ }^{24}$ Para Augusto Cançado Trindade: "A visão compartimentalizada dos direitos humanos pertence ao passado, e, como reflexo dos confrontos ideológicos de outrora, já se encontra muito superada. $O$ agravamento das disparidades sócio-econômicas entre os países, e entre as camadas sociais dentro de cada país, provocou uma profunda reavaliação das premissas das categorizações de direitos. A fantasia nefasta das chamadas "gerações de direitos", histórica e juridicamente infundada, na medida em que alimentou uma visão fragmentada ou atomizada dos direitos humanos, já se encontra devidamente desmistificada. O fenômeno que hoje testemunhamos não é o de uma sucessão, mas antes de uma expansão, cumulação e fortalecimento dos direitos humanos consagrados, consoante uma visão necessariamente integrada de todos os direitos humanos." (CANÇADO TRINDADE, Antônio Augusto. Tratado de Direito Internacional dos Direitos Humanos, vol. 1. 2a Edição. Porto Alegre: Sergio Antonio Fabris Editor, 1997. P.488).
} 
culturais), e.g., direito à educação, ao trabalho, ao lazer e à vida cultural; e de uma nova geração que estava surgindo naquele momento: a terceira (direitos difusos e dos povos), quando consagrou em seu texto a paz e a fraternidade. Hodiernamente, tem-se reconhecido a existência da quarta e quinta gerações, que englobam biodireitos, direitos das minorias e outros.

A partir da Declaração Universal dos Direitos Humanos, os direitos humanos adquirem os caracteres de universalidade ("são aplicáveis a todas as pessoas de todos os países, raças, religiões e sexos; seja qual for o regime político dos territórios nos quais incide" 25 , muito embora esta característica seja criticada com base na imposição dos valores ocidentais sobre os orientais), indivisibilidade (de modo que uma geração não substitui a outra, mas interagem entre si), interdependência e interrelação. ${ }^{26}$

Após este breve histórico dos direitos humanos, conclui-se que eles são conquistas de um determinado tempo histórico, e não "direitos naturais". A posição aqui adotada é no sentido de interpretar os direitos humanos como sendo uma construção realizada através de diferentes etapas do homem moderno, cujo ápice foi a cristalização e afirmação destes direitos na Declaração Universal dos Direitos Humanos de 1948. Trata-se do início de um processo cujo horizonte nos levará à conquista de novos direitos, aumentando-se, assim, seu catálogo. Nas palavras de Norberto Bobbio:

"Sabemos hoje que também os direitos ditos humanos são o produto não da natureza, mas da civilização humana; enquanto direitos históricos, eles são mutáveis, ou seja, suscetíveis de transformação e ampliação. (...) Os Direitos elencados na Declaração não são os únicos e possíveis direitos do homem: são os direitos do homem histórico, tal como este se configurava na mente dos redatores da Declaração após a tragédia da Segunda Guerra Mundial. (...) A Declaração Universal representa a consciência histórica que a humanidade tem dos próprios valores fundamentais na segunda metade do

\footnotetext{
${ }^{25}$ PIOVESAN, Flávia. Op. cit. P.137.

${ }^{26}$ A Resolução no. 32/130 (1977) da Assembleia Geral da ONU estabeleceu que "Todos os Direitos Humanos, qualquer que seja o tipo a que pertencem se interrelacionam necessariamente entre si, e são indivisíveis e interdependentes". A Declaração de Direitos Humanos de Viena (1993) reiterou o entendimento em seu artigo 50: "Todos os Direitos do homem são universais, indivisíveis, interdependentes e interrelacionados. A comunidade internacional tem de considerar globalmente os Direitos do homem, de forma justa e equitativa e com igual ênfase. Embora se devam ter sempre presente o significado das especificidades nacionais e regionais e os antecedentes históricos, culturais e religiosos, compete aos Estados, independentemente dos seus sistemas político, econômico e cultural, promover e proteger todos os Direitos do homem e liberdades fundamentais".
} 
século XX. É uma síntese do passado e uma inspiração para o futuro: suas tábuas não foram gravadas de uma vez para sempre." ${ }^{27}$

\subsection{2- A Proteção dos Direitos Culturais no Plano Internacional.}

Conforme a "árvore genealógica" dos direitos humanos discorrida no subitem anterior, tradicionalmente, os direitos culturais estão contidos naqueles oriundos da segunda geração (a par dos direitos sociais e econômicos). Baseando-se no entendimento contemporâneo dos direitos humanos, cabe aqui mencionar o entendimento do jurista português Vasco Pereira da Silva no sentido de que os direitos culturais estariam presentes, evoluindo a cada etapa, nas ditas três gerações ${ }^{28}$ :

a) Os direitos culturais surgem na primeira geração de direitos humanos como uma "liberdade" em face do Estado, que integrava as "liberdades de espírito" ou "liberdades de pensamento", encontrando-se consagrada, de forma expressa ou implícita, nas constituições liberais;

b) na segunda geração, são incluídos na categoria, junto dos sociais e econômicos, daqueles que necessitam uma prestação positiva do Estado (Estado Social);

c) por fim, na terceira e subsequentes gerações, em um contexto de um Estado Pós-Social, os direitos culturais adquirem caracteres de direitos participativos, pelo qual o Estado, com a cooperação da sociedade, formula políticas públicas culturais.

No âmbito internacional, a primeira vez em que houve a consagração dos direitos culturais foi na Declaração Universal dos Direitos Humanos, quando esta os reconheceu como sendo direitos humanos, em seus artigos 17 e 22, transcritos a seguir:

Artigo 17: 1. Toda pessoa tem direito de participar livremente da vida cultural da comunidade, de fruir as artes e de participar do progresso científico e seus benefícios; 2.Toda pessoa tem direito à proteção dos direitos morais e materiais decorrentes de qualquer produção científica, literária ou artística da qual seja autor. (grifei)

\footnotetext{
${ }^{27}$ BOBBIO, Norberto. Op. cit. P. 32-34.

${ }^{28}$ Cf. SILVA, Vasco Pereira da. A Cultura que eu tenho direito: Direitos Fundamentais e Cultura. Lisboa: Ed. Almadina, 2007. P. 36-37.
} 
Artigo 22: Toda pessoa, como membro da sociedade, tem direito à segurança social e à realização, pelo esforço nacional, pela cooperação internacional e de acordo com a organização e recursos de cada Estado, dos direitos econômicos, sociais e culturais indispensáveis à sua dignidade e ao livre desenvolvimento da sua personalidade. (grifei)

A mesma postura foi adotada, logo após, no âmbito do sistema interamericano, pela Carta da Organização dos Estados Americanos (OEA), promulgada em 1948, ao estabelecer em seu artigo 48 que os Estados membros "considerar-se-ão individual e solidariamente comprometidos a preservar e enriquecer o patrimônio cultural dos povos americanos."

No entanto, a Declaração Universal dos Direitos Humanos não foi precisa em relação à definição dos direitos culturais. Outro fator que sobressaiu no momento posterior à sua promulgação foi a limitação quanto à sua força jurídica, uma vez que se tratava de uma resolução e não de um tratado. Faltavam-lhe mecanismos de exigibilidade no âmbito internacional, gerando assim, a necessidade de um novo pacto que definisse melhor os direitos econômicos, sociais e culturais, bem como a criação de mecanismos de proteção, buscando, desta forma, uma "jurisdicização" da Declaração, que não possuía força de lei. ${ }^{29}$

Em 1966 foi adotado, tendo entrado em vigor em 1976, o Pacto Internacional sobre os Direitos Econômicos, Sociais e Culturais (PIDESC), de caráter vinculante, que impunha deveres e obrigações legais a serem cumpridos pelos países signatários. 0 PIDESC apresenta uma extensa carta de direitos de caráter programático que requerem a atuação dos Estados, que por sua vez serão monitorados através de relatórios a serem entregues ao Secretário-Geral da ONU. Os direitos culturais estão presentes no artigo 15 do PIDESC, cuja transcrição integral é:

"1. Os Estados-partes no presente Pacto reconhecem a cada indivíduo o direito de: a) Participar da vida cultural; b) Desfrutar o progresso científico e suas aplicações; c) Beneficiar-se da proteção dos interesses morais e materiais decorrentes de toda produção científica, literária ou artística de que seja autor. 2. As medidas que os Estados-partes no presente pacto deverão adotar com a finalidade de assegurar $o$ pleno exercício desses direitos incluirão aquelas necessárias à conservação, ao

\footnotetext{
${ }^{29}$ Cf. LIMA JUNIOR, Jayme Benevenuto. Op. Cit. p. 30.
} 
desenvolvimento e à difusão da ciência e da cultura. 3. Os Estados-partes no presente Pacto comprometem-se a respeitar a liberdade 4. Os Estados-partes no presente Pacto reconhecem os benefícios que derivam do fomento e do desenvolvimento da cooperação e das relações internacionais no domínio da ciência e da cultura." (grifei)

O último relatório enviado pelo Brasil em 2006 abrangeu o período entre 20012006. Além de apresentar um panorama da situação econômico-social do país e da legislação referente à cultura, elucida um avanço no tocante aos resultados das políticas culturais implementadas, ao mesmo tempo reconhece que há muito para ser realizado. $^{30}$

Também no ano de 1966, no contexto da cooperação internacional, iniciada após a Declaração Universal dos Direitos Humanos, foi promulgada a Declaração dos Princípios da Cooperação Cultural Internacional que, reconhecendo a existência de diversidade cultural no mundo, dispôs em seu artigo 1ㅇ:

"1. Toda a cultura tem uma dignidade e um valor que devem ser respeitados e salvaguardados; 2 . Todos os povos tem o direito e o dever de desenvolver as respectivas culturas. 3. Todas as culturas fazem parte do patrimônio comum da humanidade, na sua variedade fecunda, diversidade e influência recíproca."

Em 1972 foi celebrada a Convenção para a Proteção do Patrimônio Mundial, Cultural e Natural cuja finalidade é resguardar monumentos (incluem-se obras arquitetônicas, esculturas, pinturas, inscrições etc.), sítios (incluem-se obras conjugadas do homem com a natureza), bens naturais e paisagens culturais que possuem relevância cultural para a Humanidade, diante de sua monumentalidade e

\footnotetext{
${ }^{30}$ A título exemplificativo, o II Relatório sobre o Cumprimento do Pacto Internacional de Direitos Econômicos, Sociais e Culturais pelo Brasil apresenta as seguintes estatísticas: "a frequência a cinemas, museus, teatros e bibliotecas é feita por uma minoria. Nunca vão ao cinema $68 \%$ do total, a museus $78 \%$, ao teatro $83 \%$ e nunca retiram livro em biblioteca $69 \%$. A frequência é um pouco maior na medida em que aumenta o nivel de letramento e aumenta a classe de renda. Portanto, além do hábito intencionado para certas atividades culturais, outras variáveis convergem para criar as condições de exercício desses hábitos, todas elas relacionadas ao nível sócio-econômico, ao entorno social e à presença de instituições e espaços organizados para a fruição e exercício das práticas." (BRASIL. Minuta Consulta Pública - II Relatório Sobre o Cumprimento do PIDESC. Disponível em <http://www.dhescbrasil.org> Acesso em 09 set.2011.
} 
excepcionalidade. ${ }^{31}$ Cabe aos países signatários, através do Comitê do Patrimônio Mundial, selecionar quais áreas deverão ser incluídas no rol de proteção, respeitandose a soberania dos países proprietários sobre tais bens. O documento gera uma obrigação para que os Estados signatários protejam os sítios e ajam de forma cooperativa para a difusão e proteção dos bens selecionados.

A Convenção também criou o Fundo do Patrimônio Mundial. Trata-se de instrumento pelo qual os países signatários, que são obrigados a preservar os bens situados em seus territórios, após o esgotamento dos seus recursos internos e na hipótese de emergência, poderão solicitar verbas, para fins de restauração e proteção de bens listados que se encontrem em perigo. Deflagra-se aqui mais um caso de cooperação internacional, tendo em vista que todos os países signatários contribuem e podem ser beneficiários do Fundo.

Os últimos 20 anos viram surgir diversos documentos internacionais cujos objetos envolvem a proteção de direitos culturais, reafirmando-se, assim, a importância dada pelos Estados quanto à questão cultural, reconhecida como sendo fundamental no contexto de cooperação entre os Estados. Destacam-se dentre os que foram ratificados pelo Brasil e que se encontram atualmente em vigor a Carta Democrática Interamericana da OEA (2001) ${ }^{32}$, a Convenção sobre a Diversidade Cultural da UNESCO (2001) ${ }^{33}$ e a Convenção para Salvaguarda do Patrimônio Cultural

\footnotetext{
${ }^{31}$ O Brasil aprovou a Convenção do Patrimônio Mundial em 1977 por via do Decreto no 80.978. As cidades de Ouro Preto e Diamantina (MG), Olinda (PE), Brasília (DF) e as Cataratas do Iguaçu (PR) são exemplos de bens brasileiros considerados Patrimônio da Humanidade.

${ }^{32} \mathrm{O}$ artigo 13 da Carta consagra que "A promoção e observância dos direitos econômicos, sociais e culturais são inerentes ao desenvolvimento integral, ao crescimento econômico com equidade e à consolidação da democracia dos Estados do Hemisfério."

${ }^{33}$ Inês Virgínia Prado Soares reconhece a importância da Convenção sobre a Diversidade Cultural, pois "destaca que a cultura se encontra no centro dos debates contemporâneos sobre a identidade, a coesão social e o desenvolvimento de uma economia fundada no saber. A promoção da diversidade cultural, o incentivo ao diálogo cultural, o reconhecimento da importância da cultura para o desenvolvimento dos países e a reafirmação do direito soberano dos Estados signatários em adotarem e implementarem as políticas e medidas que sejam necessárias para a promoção da diversidade cultural são os principais objetivos da aludida Convenção." (SOARES, Inês Virgínia Prado. Direito ao (do) Patrimônio Cultural Brasileiro. Belo Horizonte: Ed. Fórum, 2009. P. 73).
} 
Imaterial (2003) ${ }^{34}$. Vale citar também a recente Resolução 10/23 da ONU (2009) que nomeou, através do Conselho de Direitos Humanos, um "perito independente no campo dos direitos culturais", com mandato de duração de três anos, para identificar, através de investigações, relatórios e recomendações, as melhores práticas no que se referem à proteção dos direitos culturais nos âmbitos local, regional e internacional, assim como promover a cooperação entre os Estados para que os direitos culturais sejam promovidos e respeitados. ${ }^{35}$

Pode-se concluir que todos os documentos internacionais citados neste subitem procuram a proteção dos direitos humanos culturais enquanto defesa de um mínimo ético irredutível a ser resguardado pela comunidade internacional, gerando, assim, um lastro e uma obrigação para que os Estados em seus ordenamentos jurídicos internos criem normas e mecanismos para sua proteção e efetividade. Ao tratar deste tema, Inês Virgínia Prado Soares leciona que:

"Como direitos humanos, os direitos culturais se desenvolveram numa dinâmica social na qual os instrumentos políticos, jurídicos, sociais, econômicos e culturais são utilizados coma finalidade de garantir o amplo acesso aos bens culturais (bens materiais ou imateriais de valor simbólico, afetivo, arqueológico, artístico, histórico, paisagístico, turístico, bens relativos à manifestação cultural, à criação humana, às formas de expressão e ao modo de fazer, criar e viver etc.). Desta forma, os direitos humanos culturais não necessitam somente de uma garantia formal - a sua declaração

\footnotetext{
${ }^{34}$ A Convenção para Salvaguarda do Patrimônio Cultural Imaterial amplia a proteção concedida pela Proteção do Patrimônio Mundial, uma vez que reconhece a importância e sua consequente necessidade da tutela pelos Estados signatários do denominado Patrimônio Cultural Imaterial, que por definição contida no documento, são "as práticas, representações, expressões, conhecimentos e técnicas - junto com os instrumentos, objetos, artefatos e lugares culturais que Ihes são associados - que as comunidades, os grupos e, em alguns casos, os indivíduos reconhecem como parte integrante de seu patrimônio cultural. Este patrimônio cultural imaterial, que se transmite de geração em geração, é constantemente recriado pelas comunidades e grupos em função de seu ambiente, de sua interação com a natureza e de sua história, gerando um sentimento de identidade e continuidade e contribuindo assim para promover o respeito à diversidade cultural e à criatividade humana" (artigo 2.1).

35 A atual Especialista Independente de Direitos Culturais da ONU é a socióloga paquistanesa Farida Shaheed. Em entrevista à Revista Observatório Itaú Cultural, ela explicou, com suas palavras, a função de seu cargo: "Em termos mais específicos, como especialista independente no campo dos direitos culturais, minha função é a de estudar a relação entre os direitos culturais e a diversidade cultural e identificar as melhores práticas, assim como os obstáculos, presentes na promoção e na proteção dos direitos culturais nos níveis local e internacional, na perspectiva do gênero e das incapacidades. Com base em estudos e interações, espera-se que eu faça sugestões de medidas e ações concretas para promover e proteger os direitos culturais que possam ser adotadas pelos Estados e pelo Conselho de Direitos Humanos." COELHO, Teixeira. O novo Papel dos Direitos Culturais - Entrevista com Farida Shaheed, da ONU. In: Revista Observatório Cultural - no 11. São Paulo: Itaú Cultural, 2011. P. 18-19.
} 
em Cartas internacionais e nas Constituições, mas da garantia real, que se revela pelo aparato estabelecido pela sua fruição." 36

Cabe, por fim, analisar o tratamento dado pela Constituição Federal de 1988 aos tratados internacionais de direitos humanos. Diante do silêncio constitucional no que diz respeito à relação entre direito internacional e interno, a incorporação dos tratados internacionais é uma questão polêmica, e segundo Gustavo Binenbojm, irrelevante ${ }^{37}$, que até hoje não foi pacificada na doutrina brasileira, sendo alvo de inúmeras divergências no que tange às suas sistemáticas (monista e dualista). Não deve aqui ser o tema aprofundado, pois não é este o foco do presente trabalho. Seu tratamento será restringido aqui ao entendimento de Flávia Piovesan no sentido de que o Brasil, no tocante à internalização dos tratados que versam sobre direitos humanos, adota a concepção monista do Direito, isto é, tanto o Direito Interno quanto o Direito Internacional compõem uma única ordem jurídica, sem limites que os separam. Ademais, deve ser destacada a inovação trazida pela Emenda Constitucional n 45 (2004) que, embora redigida de maneira confusa, concede aos tratados internacionais de direitos humanos a equivalência de emenda constitucional, desde que ratificados pelo Brasil e aprovados pelo Congresso, em dois turnos, por três quintos dos votos dos respectivos membros. Nas palavras da autora:

"Embora essa seja a doutrina dominante (aqui a autora se refere ao sistema dualista, ou seja, a norma internacional só vale quando for transformada em lei interna), este trabalho sustenta que tal interpretação não se aplica aos tratados de direitos humanos, que, por força do art. 5o, § 1ํ, tem aplicação imediata. Isto é, diante do princípio da aplicabilidade imediata das normas definidoras de direitos e garantias fundamentais, os tratados de direitos humanos, assim que ratificados, devem irradiar efeitos na ordem jurídica internacional e interna, dispensando a edição de decreto de execução. (...) Ademais, (...) a Carta de 1988 confere aos tratados de direitos humanos o status de norma constitucional, por força do art. 5o, §£ 20 e 3‥" 38

A seguir, ela conclui que:

\footnotetext{
${ }^{36}$ SOARES, Inês Virgínia Prado. Op. Cit. P. 70.

${ }^{37}$ V. BINENBJOM, GUSTAVO. Monismo e Dualismo no Brasil: uma dicotomia afinal irrelevante. In:Revista Forense, vol. 350. Rio de Janeiro: Editora Forense, 2000. P. 39-56.

${ }^{38}$ PIOVESAN, Flávia. Op. cit. p. 89-90.
} 
"Cabe, assim, ao Poder Judiciário e aos demais Poderes Públicos assegurar a implementação no âmbito nacional das normas constitucionais de proteção dos direitos humanos ratificados pelo Estado brasileiro. As normas internacionais que consagram direitos e garantias fundamentais tornam-se passiveis de reinvindicação e pronta aplicação ou execução perante o Poder Judiciário, na medida em que são plenamente aplicáveis. Os indivíduos tornam-se, portanto, beneficiários diretos de instrumentos internacionais voltados à proteção dos direitos humanos." ${ }^{39}$

\section{2 - O Direito Fundamental à Cultura na Constituição Federal de 1988.}

\subsection{1 - Características Gerais dos Direitos Fundamentais na Constituição Federal de 1988.}

No item anterior deste capítulo foram estudadas as características gerais dos direitos humanos focalizando nos direitos culturais, bem como sua história e os esforços envidados pela comunidade internacional através de uma cooperação entre os países nos séculos XX e XXI para sua observância, proteção e propagação, objetivando sua efetivação. Serão analisados agora no item 2.2 os direitos humanos positivados na Constituição Federal de 1988. Ressalta-se que não há pretensão do autor em abordar de forma aprofundada os aspectos, características e fundamentalidades dos direitos fundamentais na Constituição, devido à sua extensão e complexidade.

Após mais de vinte anos (1964-1985) sob a égide de uma ditadura militar pela qual os cidadãos brasileiros presenciaram e, obviamente, sentiram uma intensa supressão de direitos e garantias fundamentais, a despeito das Constituições vigentes neste período histórico que apresentavam capítulos referentes ao tema, foi promulgada em 5 de outubro de 1988 uma nova Constituição Federal, democrática,

\footnotetext{
${ }^{39}$ Ibid. P. 93.
} 
dogmática, rígida ${ }^{40}$ e formal ${ }^{41}$, que consagra um amplo catálogo de direitos fundamentais e garantias, algo sem precedentes na história constitucional brasileira.

As expressões "direitos humanos" e "direitos fundamentais" são usualmente consideradas e utilizadas como equivalentes. No entanto, o Poder Constituinte Brasileiro optou pela última. Pela primeira vez na história constitucional brasileira tal expressão foi empregada, em um quadro que consagrara anteriormente em seus capítulos os termos "garantias dos direitos civis e políticos" (1824), "declarações de direitos" (1891), "direitos e garantias individuais" (1934, 1937, 1946, 1967 e até mesmo a Emenda Constitucional no 1 de 1969). Ressalta-se que a Carta Magna de 1988 também emprega a expressão "direitos humanos" em seu artigo 40, inciso II ("A República Federativa do Brasil rege-se nas relações internacionais pelos seguintes princípios: II - prevalência dos direitos humanos"), como também "direitos e liberdades constitucionais" em seu artigo 5ㅇ, inciso LXXI (conceder-se-á mandado de injunção sempre que a falta de norma regulamentadora torne inviável o exercício dos direitos e liberdades constitucionais (...)) e "direitos e garantias individuais" em seu artigo 60, § 4ํ, inciso IV ("não será objeto de deliberação a proposta de emenda constitucional: IVos direitos e garantias individuais.").

\footnotetext{
${ }^{40}$ A Constituição Federal de 1988 é democrática, pois se origina de uma Assembleia Constituinte cujos representantes para elaborá-la foram escolhidos pelo povo, dogmática, pois elabora os dogmas ou ideias fundamentais da teoria política e dos direitos dominantes no momento, e rígida, portanto escrita, porque só pode ser alterada através de processos, solenidades e exigências formais especiais, diferentemente das leis complementares e ordinárias. Emana de sua rigidez a supremacia da Constituição, encontrando-se, assim no topo do ordenamento jurídico do país. (Cf. SILVA, José Afonso da. Op. Cit. P. 40 e seguintes.)

${ }^{41}$ Para o mesmo autor, o sentido formal da Constituição, relacionado com sua característica rígida, é " $a$ peculiar forma de existir do Estado, reduzida, sob forma escrita, a um ou mais documentos solenemente estabelecidos pelo poder constituinte e somente modificáveis por processos e formalidades especiais previstos no texto constitucional. Todas as normas insertas nesse documento-ato do poder constituinte são constitucionais, pouco importando o seu conteúdo. Juridicamente, não há distinção a ser feita entre prescrições constitucionais escritas, para o fim de considerarem-se umas como de constituição e outras, não. É verdade que muitas disposições que figuram nas constituições modernas não tem natureza estrita de regras constitucionais. Ma,s pelo fato de constarem delas, recebem o conceito de normas constitucionais em razão do documento a que aderem." (SILVA, José Afonso da. Aplicabilidade das Normas Constitucionais. 4a Ed. São Paulo: Ed. Malheiros, 2000. P. 39).
} 
Para elucidar a questão referente à diferença terminológica, cabe citar as palavras de Ingo Sarlet, que considera a utilização pela Constituição pátria do termo "direitos fundamentais" como a mais correta:

"Em que pese sejam ambos os termos (" direitos humanos" e "direitos fundamentais") comumente utilizados como sinônimos, a explicação corriqueira e, diga-se de passagem, procedente para a distinção é de que o termo "direitos fundamentais" se aplica para aqueles direitos do ser humano reconhecidos e positivados na esfera do direito constitucional positivo de determinado Estado, ao passo que a expressão "direitos humanos" guardaria relação com documentos de direito internacional, por referir-se àquelas posições jurídicas que se reconhecem ao ser humano como tal, independentemente de sua vinculação com determinada ordem constitucional, e que, portanto, aspiram à validade universal, para todos os povos e tempos de tal sorte que revelam um inequívoco de caráter supranacional (internacional). " 42

Neste mesmo sentido é o pensamento de José Afonso da Silva:

"Direitos Fundamentais do homem constitui a expressão mais adequada a este estudo, porque, além de referir-se a princípios que resumem a concepção do mundo $e$ informam a ideologia política de cada ordenamento jurídico, é reservada para designar, no nível do direito positivo, aquelas prerrogativas e instituições que ele concretiza em garantias de uma convivência digna, livre e igual de todas as pessoas." 43

O mesmo autor complementa o entendimento anterior argumentando que 0 qualitativo "fundamentais" se deve às "situações jurídicas sem as quais a pessoa humana não se realiza, não convive, e às vezes nem mesmo sobrevive." 44 O que o Constituinte buscou através desta espécie de direitos é reconhecer e efetivar, materialmente e formalmente, a proteção à liberdade, à igualdade e à dignidade da pessoa humana. ${ }^{45}$ Para Flavia Piovesan, a Constituição Federal de 1988 intentou uma reaproximação entre a ética e o direito, bem como um reencontro com o pensamento Kantiano:

"Há um reencontro com o pensamento kantiano, com as ideias de moralidade, dignidade, direito cosmopolita e paz perpétua. Para Kant, as pessoas devem

\footnotetext{
42 SARLET, Ingo Wolfgang. A Eficácia dos Direitos Fundamentais. Porto Alegre: Editora do Advogado, 1998. P. 31.

${ }^{43}$ SILVA, José Afonso da. Op. Cit. 178.

${ }^{44}$ Ibid. p. 178.

${ }^{45}$ Cf. ibid. p. 178-179.
} 
existir como um fim em si mesmo e jamais como um meio, a ser arbitrariamente usado para aquele ou este propósito." 46

Logo no início de seu texto, a Constituição inova ao reconhecer a importância do princípio da dignidade da pessoa humana, positivando-o, em seu artigo $1 \stackrel{0}{\circ}$, inciso III, como um dos fundamentos que regem a República Federativa do Brasil. Na concepção do ilustre constitucionalista português Jorge Miranda, a Constituição Portuguesa, assim como a nossa, "repousa na dignidade da pessoa humana, proclamada no art. 1으, ou seja, na concepção que faz da pessoa fundamento e fim da sociedade e do Estado." 47 Sendo um valor e princípio fundamental na Constituição, a dignidade da pessoa humana, portanto, "exige e pressupõe o reconhecimento e proteção dos direitos fundamentais de todas as dimensões." 48

O Título II da Constituição Cidadã denomina-se "Dos Direitos e Garantias Fundamentais". Contém em seus quatro capítulos normas referentes a direitos e deveres individuais e coletivos (artigo 50, que conta atualmente com 78 incisos), direitos sociais (artigos 6ㅇ e 7으, este último contendo normas de direitos trabalhistas), direitos da nacionalidade e direitos políticos. No entanto, os direitos fundamentais que estão contidos no Título II não foram identificados como presentes em um rol taxativo, mas sim, como ensina Jorge Miranda, em "uma enumeração aberta, sempre pronta a ser preenchida ou completada através de outros direitos." 49

Tomando aqui como base a afirmação de Carlos Roberto Siqueira Castro que "o Estado Constitucional Democrático da atualidade é um Estado de abertura constitucional radicado no princípio da dignidade do ser humano" ${ }^{50}$, pode-se concluir que o Constituinte, através da dicção do art. 5ำ, § 2 ("Os direitos e garantias expressos nesta Constituição não excluem outros decorrentes do regime e dos princípios por ela

\footnotetext{
${ }^{46}$ PIOVESAN, Flavia. Op.cit. P. 29.

${ }^{47}$ MIRANDA, Jorge. Manual de Direito Constitucional. Tomo IV. Coimbra: Ed. Coimbra,1988. P. 166-67

${ }^{48}$ SARLET, Ingo Wolfgang. Dignidade da pessoa humana e direitos fundamentais na Constituição Federal de 1988. 4a. Ed. Porto Alegre: Livraria do Advogado, 2006. P. 84-85.

${ }^{49}$ MIRANDA, Jorge. Op. Cit. P. 153.

50 CASTRO, Carlos Ribeiro Siqueira. A Constituição Aberta e os direitos fundamentais: ensaios sobre o constitucionalismo pós-moderno e comunitário. Rio de Janeiro: Ed. Forense, 2003. P. 19.
} 
adotados, ou dos tratados internacionais em que a República Federativa do Brasil seja parte"), adotou ideia de abertura material do catálogo constitucional de direitos e garantias fundamentais.

Ingo Sarlet corrobora com a afirmação:

"À luz do direito constitucional pátrio, verifica-se, de plano, ser inviável a sustentação, também entre nós, da concepção segundo a qual os direitos fundamentais formam um sistema em separado e fechado dentro da Constituição. (...) Em primeiro lugar, cumpre referir que o conceito materialmente aberto de direitos fundamentais consagrado pelo art. 5ㅇ, §2으, da CF aponta para a existência de direitos fundamentais positivados em outras partes do texto constitucional e até mesmo em tratados internacionais, bem como decorrentes do regime e dos princípios da Constituição." ${ }^{51}$

No que tange às características dos direitos fundamentais, são eles: a) históricos (como qualquer direito, são frutos de conquistas no decorrer da História do Homem que vão evoluindo e multiplicando-se, e não oriundos da doutrina do direito natural); b) inalienáveis (não possuem caráter econômico-patrimonial, logo, são intransferíveis, inegociáveis e indisponíveis); c) imprescritíveis (não há prazo para que deixem de ser exigíveis, diferentemente dos direitos de cunho econômico-patrimonial) e; d) irrenunciáveis (alguns dos direitos fundamentais podem não ser exercidos, mas nunca renunciados). ${ }^{52}$

Vasco Pereira da Silva compreende que todos os direitos fundamentais apresentam uma natureza "duplamente dupla", uma vez que simultaneamente: (i) possuem uma dimensão negativa, pois protege seus titulares de agressões provenientes de entidades públicas ou privadas, e positiva, ao obrigar que os poderes públicos ajam para sua concretização; (ii) possuem uma dimensão subjetiva, como direitos subjetivos públicos, ao mesmo tempo em que uma dimensão objetiva, como princípios jurídicos ou estruturas objetivas da sociedade. ${ }^{53}$ Por ser um direito subjetivo público, possui os seguintes elementos: trata-se de um direito de não agressão, ou de liberdade em face de agressões públicas; um direito a atuações dos poderes públicos

\footnotetext{
${ }^{51}$ SARLET, Ingo. Op. cit. p. 75.

${ }^{52}$ Cf. SILVA, José Affonso da. Op. Cit. P. 181.

${ }^{53}$ SILVA, Vasco Pereira da. Op. Cit. P. 114.
} 
delineados nas normas constitucionais; direito a um mínimo de intervenção estatal; e direito a uma proteção do Estado contra agressões oriundas de entidades privadas. ${ }^{54}$

Acrescenta-se que os Direitos Fundamentais receberam proteção especial pelo Poder Constituinte Originário brasileiro, no que se refere ao seu aspecto material, pois Ihes conferiu o caractere de cláusula pétrea (art. 60, § 4ㅇ, inciso IV), adotando-se aqui uma interpretação ampliativa de seu enunciado. O referido artigo, nas palavras de Paulo Bonavides, "consagra as vedações materiais perpétuas do nosso ordenamento jurídico constitucional ao exercício do poder de reforma." 55 Outrossim, uma outra inovação do Constituinte foi explicitar no artigo 50, §1으, da CF/88 que "as normas definidoras de direitos e garantias fundamentais tem aplicabilidade imediata." Isto significa que são aplicáveis até onde possam dentro de condições oferecidas pelas instituições para seu atendimento, e que o Poder Judiciário deve aplicá-las, quando provocado em um caso concreto, conferindo ao interessado o direito reclamado. ${ }^{56}$

A Constituição Federal de 1988, embora utilize os termos direitos e garantias individuais e direitos sociais e culturais separadamente, de forma tendenciosa a serem compreendidos como contrapostos, na realidade, assumiu a integração de todas as gerações de direitos fundamentais, à guisa dos princípios da indivisibilidade e interdependência dos Direitos Humanos. Para José Afonso da Silva, que reconhece seis diferentes grupos de direitos fundamentais na Constituição, dentre eles direitos individuais, direitos à nacionalidade, direitos políticos, direitos sociais (nele incluído o direito fundamental à cultura), direitos coletivos e direitos solidários, aduz que:

"As categorias de direitos humanos fundamentais, nela previstos, integram-se num todo campo harmônico, mediante influências recíprocas, até porque os direitos individuais, consubstanciados no seu art. 5o, estão contaminados de dimensão social, de tal sorte que a previsão dos direitos sociais, entre eles, os direitos de nacionalidade e políticos, Ihes quebra o formalismo e o sentido abstrato." 57

\footnotetext{
${ }^{54}$ Cf. Ibid. P. 122-123.

${ }^{55}$ BONAVIDES, Paulo. Curso de Direito Constitucional, 7a Ed. São Paulo: Ed. Malheiros, 1997. P. 177.

${ }^{56}$ Cf. SILVA, José Afonso da. Op. Cit. P. 165.

${ }^{57}$ Id. Op. cit. P. 185.
} 
Desta maneira, todos os direitos fundamentais, mesmo de diferentes dimensões, dialogam entre si, sem uma hierarquia pré-definida. É importante pontuar que não há direito fundamental absoluto, o que pode acabar por gerar uma colisão de direitos. Assim, o intérprete deve ponderar, no caso concreto, os bens jurídicos tutelados, os interesses e os valores envolvidos, sempre à luz do princípio fundamental da dignidade da pessoa humana.

Para ilustrar a harmonização dos direitos fundamentais, tomemos como exemplo a afirmação contida no excerto que inicia o capítulo, extraído da obra "A Luta pela Cultura", de Nelson Werneck Sodré: para a concretização do princípio democrático consagrado pela Constituição Federal de 1988, será necessário que seja respeitada pelo Estado a liberdade pública de expressão (art. 50, inciso IX:" é livre a expressão da atividade intelectual, artística, científica e de comunicação, independentemente de censura ou licença" $)^{58}$, a fim de que seja garantido o exercício dos direitos culturais previstos na Constituição (na terminologia adotada por José Afonso da Silva, seria uma liberdade de expressão cultural ${ }^{59}$, direitos estes que serão estudados no subitem a seguir.

\subsection{2 - A "Constituição Cultural": O Direito Fundamental à Cultura na Constituição Federal de 1988 e a Eficácia de suas Normas.}

No item 2.2.1, foi visto que a Constituição Federal de 1988 comportou uma abertura material do catálogo constitucional de direitos e garantias fundamentais, logo, para ser um direito fundamental, não é necessário que ele somente esteja contido no rol de direitos previstos em seu Título II. Quando o legislador constituinte tratou de forma específica do direito fundamental à cultura, embora localizado topograficamente

\footnotetext{
${ }^{58} \mathrm{Na}$ definição de Luis Roberto Barroso, as liberdades públicas "delimitam espaços da esfera individual que não podem, a princípio e por princípio, ser invadidos pelo Estado. (...) São conquistas da humanidade na luta contra a tirania e o poder irresponsável." (BARROSO, Luís Roberto. Eficácia e efetividade do direito à liberdade in: Temas de Direito Constitucional. Rio de Janeiro: Ed. Renovar, 2001. p.87).

${ }^{59}$ Cf. SILVA, José Afonso da. Op. Cit.. São Paulo: Ed. Malheiros, 2001. P. 58.
} 
de modo distante do artigo 5o, este se fez presente no Capítulo III (Da Educação, da Cultura e do Desporto) do Título VIII (da Ordem Social).

Devido à importância dada à cultura ao ser elevada ao status de direito fundamental, deflagra-se uma Constituição Cultural, em outras palavras, a ordenação constitucional da cultura. Em notável estudo sobre o art. 73 da Constituição da República Portuguesa de 1976, reiterado na doutrina pátria por José Afonso da Silva ${ }^{60}$, observa José Gomes Canotilho:

"Ao incluir uma "constituição cultural", a CRP constitui o Estado, de certo modo, em Estado cultural ou Estado de cultura. Ele é, por um lado, um Estado de Direito Cultural, obrigado a respeitar a liberdade e a autonomia cultural dos cidadãos (liberdades culturais); é, por outro lado, um Estado democrático cultural, empenhado no alargamento e na democratização da cultura (direitos à cultura). São esses direitos à cultura (enunciados no presente capítulo) que consubstanciaram também o conceito de democracia cultural (art. 2, in fine) baseado, por um lado, na generalização do acesso à cultura e à fruição cultural e, por outro lado, na participação da política cultural. "161

Em sua importante obra para o tema, A Cultura a que Eu Tenho Direito: Direitos Fundamentais e Cultura ${ }^{62}$, o constitucionalista português Vasco Pereira da Silva entende o direito fundamental à cultura como: i) um direito subjetivo de não agressão por parte das autoridades públicas que, por exemplo, assegura seu titular a defesa contra a censura, contra a proibição de acesso a espetáculos, contra violações de direitos de autor, contra a proibição de um acesso a um monumento público; ii) um direito subjetivo a prestações por parte do Poder Público correspondentes a deveres de atuação concretos e determinados consagrados nas normas constitucionais, de maneira expressa ou implícita; iii) um direito subjetivo a uma "prestação cultural mínima", de modo a garantir a inexistência de situações extremas de "grau zero de cultura", como, por exemplo, a total ausência de bens culturais em estabelecimentos

\footnotetext{
${ }^{60}$ Para o autor, a constituição cultural é formada a partir da relevante importância dada à cultura pela Constituição Federal de 1988. O termo cultura nela abrange "a formação educacional do povo, expressões criadoras da pessoa e das projeções do espírito humano materializadas em suportes expressivos, portadores de referências à identidade, ação, à memória dos diferentes grupos da sociedade brasileira" (SILVA, José Afonso da. Op. Cit. P. 840).

${ }^{61}$ CANOTILHO, José Joaquim Gomes; MOREIRA, Vital. Constituição da República Portuguesa Anotada. 2a. Ed. 1 o vol. Coimbra: Ed. Coimbra, 1984. P. 361.

${ }^{62}$ Cf. SILVA, Vasco Pereira da. Op. Cit. P. 128-130.
} 
públicos ou recusa por parte do Poder Público em exercer suas competências de fomentar e apoiar as atividades culturais; iv) um direito subjetivo de proteção estadual contra agressões de entidades privadas, como, por exemplo, vandalizar ou destruir salas de espetáculos; v) um direito objetivo que cria normas de competência negativa, critérios de interpretação de todo o ordenamento jurídico e princípios programáticos a serem concretizados pelo Poder Público "tanto quanto (ou na medida) do possível".

Na Constituição Federal de 1988, a cultura é tratada de modo abundante, estando presente em diferentes enunciados. No artigo 5o, é consagrada nos incisos IV e IX (liberdade de expressão cultural), XXVII e XXVIII (direitos de autor e conexos), e no LXXIII (ação popular para proteger o patrimônio histórico e cultural). Seus artigos 23 (incisos III, IV, V), 24 (incisos VII a IX) e 30 (incisos II e IX) delineiam as competências da União, Estados e Municípios no tocante à matéria cultural. 0 artigo 219 estipula que o mercado interno "será incentivado de modo a viabilizar o desenvolvimento cultural e sócio-econômico". O artigo 221 (incisos I, II e III) define os princípios a serem seguidos por emissoras de rádio e televisão, visando à valorização e propagação da cultura nacional e regional. Além destes, possui assento também nos artigos 227 (o direito à cultura como um dever da família, da sociedade e do Estado que deve ser garantido à criança, ao adolescente e ao jovem) e no artigo 231, que estabelece proteção à cultura indígena.

Frisa-se que foi nos artigos 215 e 216 que o Constituinte nos deu um norte para definirmos o Direito Fundamental à Cultura, quando criada uma seção específica sobre o tema. O artigo 215 prevê a garantia do pleno exercício dos direitos culturais e acesso às fontes da cultura nacional; o apoio e incentivo à valorização e difusão das manifestações culturais; a proteção de manifestações culturais populares dos grupos participantes do processo civilizatório nacional (incluem-se aí manifestações indígenas, afro-brasileiras e dos demais grupos participantes do processo civilizatório nacional); estabelece que lei fixará datas comemorativas de caráter significativo para diferentes segmentos étnicos nacionais e a criação do Plano Nacional de Cultura, objeto de estudo 
do terceiro capítulo. De acordo com José Afonso da Silva, o artigo 215 da Constituição reconhece os seguintes direitos culturais:

"a) liberdade de expressão da atividade intelectual, artística, científica; b) direito de criação cultural, compreendidas as criações artísticas, científicas e tecnológicas; c) direito de acesso às fontes da cultura nacional; d) direito de difusão das manifestações culturais; e) direito de proteção às manifestações das culturas populares indígenas $e$ afro-brasileiras e de outros grupos participantes do processo civilizatório nacional; f) direito-dever estatal de formação do patrimônio cultural brasileiro e de proteção dos bens de cultura - que, assim, ficam sujeitos a um regime jurídico especial, como forma de propriedade de interesse público." 63

O artigo 216 ampliou e democratizou a definição do patrimônio cultural brasileiro ${ }^{64}$, abrindo mão da vetusta e limitada expressão "patrimônio histórico e artístico nacional”. Estipula que o Poder Público, com a colaboração da comunidade, o promoverá e protegerá através de inventários, registros, vigilância, tombamento e desapropriação, dentre outras possibilidades para tutela e preservação. Define que a administração pública será responsável pela gestão da documentação governamental, providenciando o acesso para sua consulta quanto necessitado. Ademais, estabelece que ficam tombados todos os documentos e sítios possuidores de reminiscências históricas dos quilombos e que os danos ao patrimônio cultural serão punidos na forma da lei. Em termos de financiamento à cultura, seus $\S \S 30$ e 60 estabelecem que a lei incentivará a produção e conhecimento de bens e valores culturais, como faculta aos Estados e Distrito Federal a criação de um fundo estadual de cultura, respeitados os cinco décimos de sua receita tributária líquida para apoio e financiamento de programas e projetos culturais. Coloca-se que este último dispositivo não foi efetivado por nenhum Estado ou pelo Distrito Federal até o ano de 2011.

\footnotetext{
${ }^{63}$ SILVA, José Afonso da. Op. Cit. P. 51-51.

64 "Art. 216: Constituem patrimônio cultural brasileiro os bens de natureza material e imaterial, tomados individualmente ou em conjunto, portadores de referência à identidade, à ação, à memória dos diferentes grupos formadores da sociedade brasileira, nos quais se incluem: I - as formas de expressão; II- os modos de criar, fazer e viver; III- as criações científicas, artísticas e tecnológicas; IV - as obras, objetos, documentos, edificações e demais espaços destinados às manifestações artístico-culturais; $V$ - os conjuntos urbanos e sítios de valor histórico, paisagístico, arqueológico, paleontológico, ecológico e científico."
} 
Definindo princípios como sendo "portadores dos valores éticos adotados pelo ordenamento", Francisco Humberto Cunha Filho reconheceu na Constituição Federal quatro que regem a normatividade cultural no Brasil. ${ }^{65}$ São eles:

a) princípio do pluralismo cultural: o Estado reconhece a possibilidade da existência e da expressão da diversidade de formas de pensamento e manifestações culturais, sem que nenhuma seja superior às outras. Sua violação acarretaria no desrespeito ao princípio democrático consagrado na Constituição Federal de 1988. O respeito ao princípio do pluralismo cultural pode ser encontrado no caput do artigo 215 (“O Estado garantirá a todos o pleno exercício dos direitos culturais (...)"), em seu § 2응 ("a lei disporá sobre a fixação de datas comemorativas de alta significação para os diferentes segmentos étnicos nacionais") e no caput do artigo 216 ("(...) à memória dos diferentes grupos formadores da sociedade brasileira") (grifos no original);

b) princípio da participação popular: as ações públicas não devem deixar de lado a participação popular no que tange à matéria cultural, uma vez que o próprio povo deve ser seu protagonista. Este princípio se faz presente no § 1 을 do artigo 216 ("O Poder Público, com a colaboração da comunidade, promoverá e protegerá o patrimônio cultural brasileiro"), no artigo 5, inciso, LXII ("qualquer cidadão é parte legítima para propor ação popular que vise anular ato lesivo (...) ao patrimônio histórico e cultural) (grifei);

c) princípio da atuação estatal como suporte logístico: o Estado deve dar suporte e apoio às atividades culturais, e não ser o produtor de cultura, devendo levar sempre em consideração a realização da igualdade material entre diferentes grupos diante de uma situação de inferioridade. Está consagrado no §10 do artigo 215 ("o Estado protegerá as manifestações das culturas populares, indígenas e afro-brasileiras, e das de outros grupos participantes do processo civilizatório nacional") e no $\S 2 \circ$ do artigo 216 ("cabem à administração pública (...) a gestão da documentação

\footnotetext{
${ }^{65} \mathrm{Cf}$. CUNHA FILHO, Francisco Humberto. Direitos Culturais como Direitos Fundamentais no Ordenamento Jurídico Brasileiro. Brasília: Brasília Jurídica, 2000. P. 45-52.
} 
governamental e as providências para franquear sua consulta a quantos dela necessitem) (grifei);

d) Princípio do respeito à memória coletiva: as práticas públicas devem considerar todo o acervo cultural na Nação e sua memória coletiva, não negligenciando seus valores. Faz-se presente no caput do artigo 216, quando a Constituição define o patrimônio cultural brasileiro; em seu $\S 2$, quando da ordem ao poder público que projeta a documentação governamental, bem como seu § 5 ("ficam tombados todos os documentos e sítios detentores de reminiscências históricas dos antigos quilombos").

Sendo, em primeiro lugar, um direito subjetivo público, pois "confere aos respectivos titulares uma posição jurídica de vantagem fundada na Constituição e que se vai refletir nas relações jurídicas (públicas ou privadas) de cultura" ${ }^{66}$, como também um "princípio jurídico objetivo orientador de políticas públicas" ${ }^{67}$, o direito à cultura pode eventualmente colidir com outros direitos ou princípios consagrados na Constituição Federal de 1988. A cultura já foi objeto de julgamento pelo Supremo Tribunal Federal em raras ocasiões, mas insta aqui citar um importante acórdão que julgou improcedente, por maioria, uma Ação Direta de Inconstitucionalidade movida pela Confederação Nacional do Comércio - CNC que pleiteava a declaração de inconstitucionalidade de uma lei estadual de São Paulo que concede meia-entrada do valor cobrado pelo ingresso em casas de diversão, de espetáculos musicais, teatrais e circenses, em cinemas etc. Tratava-se de uma colisão entre o direito fundamental à cultura e o princípio da livre iniciativa, este último consagrado nos artigos 1으, inciso IV, e 170 da Constituição. Em seu importante voto, reconhecendo que a cultura é um interesse público primário, o Relator Ministro Eros Grau consignou:

"No caso, se de um lado a Constituição assegura a livre iniciativa, de outro determina ao Estado a adoção de todas as providências tendentes a garantir o efetivo exercício do direito à educação, à cultura e ao desporto [artigos 23, inciso V, 205, 208, 215 e $217 \S$ 3o, da Constituição]. Ora, na composição princípios e regras há de ser preservado o interesse da coletividade, interesse público primário. A superação da oposição entre os desígnios de lucro e de acumulação de riqueza da empresa e o direito ao acesso à

\footnotetext{
${ }^{66}$ SILVA, Vasco Pereira da. Op. Cit. P. 114.

${ }^{67}$ PIEROTH; SCHLINK. Grundrechte - S. III, p. 15 apud SILVA, Vasco Pereira da. Op. Cit. P. 115.
} 
cultura, ao esporte e ao lazer, como meio de complementar a formação dos estudantes, não apresenta maiores dificuldades". (grifei)

A ementa do acórdão que julgou a ADIN no 1950/SP improcedente será transcrita aqui in verbis:

"AÇÃO DIRETA DE INCONSTITUCIONALIDADE. LEI N. 7.844/92, DO ESTADO DE SÃO PAULO. MEIA ENTRADA ASSEGURADA AOS ESTUDANTES REGULARMENTE MATRICULADOS EM ESTABELECIMENTOS DE ENSINO. INGRESSO EM CASAS DE DIVERSÃO, ESPORTE, CULTURA E LAZER. COMPETÊNCIA CONCORRENTE ENTRE A UNIÃO, ESTADOS-MEMBROS E O DISTRITO FEDERAL PARA LEGISLAR SOBRE DIREITO ECONÔMICO. CONSTITUCIONALIDADE. LIVRE INICIATIVA E ORDEM ECONÔMICA. MERCADO. INTERVENÇÃO DO ESTADO NA ECONOMIA. ARTIGOS 1ㅇ, 3ㅇ, 170, 205, 208, 215 e 217, \& 3, DA CONSTITUIÇÃO DO BRASIL. 1. É certo que a ordem econômica na Constituição de 1988 define opção por um sistema no qual joga um papel primordial a livre iniciativa. Essa circunstância não legitima, no entanto, a assertiva de que o Estado só intervirá na economia em situações excepcionais. 2. Mais do que simples instrumento de governo, a nossa Constituição enuncia diretrizes, programas e fins a serem realizados pelo Estado e pela sociedade. Postula um plano de ação global normativo para o Estado e para a sociedade, informado pelos preceitos veiculados pelos seus artigos 1으 3 e 170. 3. A livre iniciativa é expressão de liberdade titulada não apenas pela empresa, mas também pelo trabalho. Por isso a Constituição, ao contemplá-la, cogita também da "iniciativa do Estado"; não a privilegia, portanto, como bem pertinente apenas à empresa. 4. Se de um lado a Constituição assegura a livre iniciativa, de outro determina ao Estado a adoção de todas as providências tendentes a garantir o efetivo exercício do direito à educação, à cultura e ao desporto [artigos 23, inciso V, 205, 208, 215 e 217 § 3, da Constituição]. Na composição entre esses princípios e regras há de ser preservado o interesse da coletividade, interesse público primário. 5. $O$ direito ao acesso à cultura, ao esporte e ao lazer, são meios de complementar a formação dos estudantes. 6. Ação direta de inconstitucionalidade julgada improcedente. " 68 (grifei)

Sem estender-se no tema da eficácia das normas constitucionais, caberá agora analisá-la no que diz respeito à normatividade cultural na Constituição Federal de 1988. Tradicionalmente considerado como um direito humano de segunda geração, o direito fundamental à cultura requer não apenas uma atuação negativa do Estado (non facere) no que diz respeito às liberdades individuais e coletivas de expressões e manifestações culturais, mas, sobretudo, uma prestação positiva, prevista no próprio texto constitucional.

${ }^{68}$ STF. ADIN no 1.950/SP. Rel. Min. Eros Grau, Brasília, 03 novembro 2005. 
Utilizando-se aqui a terminologia empregada por José Afonso da Silva ${ }^{69}$, os direitos culturais na Constituição Federal de 1988 caracterizam-se como normas programáticas referidas aos Poderes Públicos em geral, ou seja: estipulam objetivos e tarefas a serem realizados por todas as esferas do Estado, como também criam parâmetros de constitucionalidade para leis e atos normativos. Diferentemente dos direitos individuais, direitos pelos quais usualmente não se questiona sua eficácia plena, os direitos culturais dependem de uma ulterior concretização legislativa para a produção de seus efeitos. Por depender de providências para sua efetivação, o direito fundamental à cultura por ser um direito social possui eficácia limitada. Todavia, não perde em momento algum o status de norma jurídica, diante da já analisada rigidez constitucional. Não se olvide que também possui aplicabilidade imediata por força do artigo 5으, § 1ㅇ da Constituição Cidadã, conforme visto no subitem anterior.

O mesmo autor, ao tratar das normas constitucionais culturais, reitera o que foi escrito até aqui:

"Não se nega que tais normas tenham menor eficácia que outras. São normas de eficácia limitada, que postulam uma providência ulterior para produzirem todos os seus efeitos. Mas não são destituídas de eficácia, porque não são simples direitos de legislação, mas direitos constitucionais atuais e fundamentais, porque devem ser compreendidos dentro do complexo marco dos direitos humanos, também reconhecidos pela Declaração Universal dos Direitos do Homem e aos quais a própria Constituição oferece algumas condições de aplicabilidade imediata." 70

No entanto, não basta que as eficácias das normas constitucionais programáticas tenham somente efeitos jurídicos. É necessário que haja eficácia social, isto é, efetividade. Isto implica dizer que a realidade deve ser concretamente transformada através do cumprimento das normas constitucionais. Para Luis Roberto Barroso, a efetividade significa

"a realização do Direito, o desempenho concreto de sua função social. Ela representa a materialização, no mundo dos fatos, dos preceitos legais e simboliza a aproximação, tão íntima quanto possível, entre o dever-ser normativo e o ser da realidade social." 71

\footnotetext{
${ }^{69}$ Cf. SILVA, José Afonso da. Op. Cit. p. 148 e seg..

${ }^{70}$ Id. Op. cit. p. 50.

${ }^{71}$ BARROSO, Luis Roberto. O direito constitucional e a efetividade de suas normas - limites $e$ possibilidades da Constituição brasileira. 9ạ edição. Rio de Janeiro: Renovar, 2009. P. 82.
} 
Deduz-se que, para a efetivação do direito fundamental à cultura, e a consequente realização da igualdade material dos cidadãos brasileiros, torna-se imprescindível uma prestação positiva do Estado pela criação de uma política cultural oficial. É através do caráter programático de sua norma que "surge a possibilidade de adaptação da forma de concretizá-lo segundo distintos programas políticos" ${ }^{72}$ que serão analisados no próximo capítulo, quando serão estudados os instrumentos hábeis para sua efetivação. Deve ser destacado que a Sociedade Civil também deve participar de forma conjunta neste processo como interessada e corresponsável, afastando-se, assim, a hipótese de uma política cultural autoritária e centralizante, conforme pontuado em um discurso realizado por Marcos Vinícios Vilaça, então Secretário de Cultura do Ministério da Educação e Cultura no ano de 1984, e eminentemente atual:

"(...) particularmente neste momento da história do País em que nos vários setores (econômico, político, social) se verifica a urgente necessidade de uma efetiva descentralização, é que, no campo da cultura, mais ainda que nos outros, não podemos jamais incorrer no engano de achar que se pode trabalhar isoladamente. $E$, quando chamo a atenção para a necessidade do trabalho conjunto, refiro-me não apenas às três esferas da administração pública, mas por igual à indispensável contribuição da iniciativa privada local, das associações civis, das entidades de classe, dos organismos de toda espécie que, conscientes de seu papel na tarefa de preservação da nossa identidade cultural, podem e tem muito a dar num esforço comum, onde as dificuldades de ordem material, financeira, orçamentária são bem conhecidas de todos." 73

\footnotetext{
${ }^{72}$ CUNHA FILHO, Francisco Humberto. Direitos Culturais no Brasil In: Revista Observatório do Itaú cultural, no 11. São Paulo: Itaú Cultural, 2011. P. 123.

${ }^{73}$ VILAÇA, Marcos Vinícios. Cultura e Estado. Brasília: Ministério da Educação e Cultura, 1985. P. 55.
} 


\title{
3. Políticas Públicas Culturais no Brasil. Mecanismos para a Efetivação do Direito Fundamental à Cultura e Tutela do Patrimônio Cultural Brasileiro.
}

\author{
"Toda a canção quer se multiplicar \\ na multidão única se tornar. \\ Simples prazer \\ de ressoar \\ no ar \\ o som da voz. \\ Canta por nós: \\ cordas vocais \\ sem cais, \\ cordas ou nós." 74
}

\section{1 - Por uma Definição de Política Cultural e seu Histórico no Brasil desde os Anos} 1930.

\subsection{1. - O que é Política Cultural.}

"O Homem é um animal político" afirmou o filósofo grego Aristóteles. Em seu contexto histórico, a Grécia Antiga, quando o cidadão (exclui-se os escravos, as mulheres e os estrangeiros) atuava para a polis (cidade), local que gozava de extrema importância para decisões naquele período, exercia um papel político. Extrai-se daí o sentido original da palavra política: "a participação dos indivíduos nos destinos da coletividade". ${ }^{75}$

Política e cultura estiveram relacionadas desde a época mencionada, quando o governo ateniense, mais especificamente no período de Péricles, incentivou o teatro através de doações monetárias para que a plateia formada somente por cidadãos fosse assistir peças e festivais realizados ao ar livre. Posteriormente, no Império Romano, destaca-se o governo de Otavio Augusto (27 a.C.- 14. a.C.), cujo ministro Mecenas

\footnotetext{
74 ZÉ, Tom. Multiplicar-se única. Disponível em <http://www.tomze.com.br>. Acesso em 12 set. 2011.

75 FEIJÓ, Martin Cezar. O que é Política Cultural. 4ạ Edição. Coleção Primeiros Passos. São Paulo: Ed. Brasiliense, 1989. P. 10-11.
} 
financiou obras que enaltecessem a figura do imperador, respaldando, assim, o poderio do Império que se encontrava em expansão. Martin Cezar Feijó reconhece neste período dois aspectos importantes:

"1) a origem da palavra mecenator, que ocorre toda vez, mesmo em períodos históricos diferentes, que artistas ou pensadores são mantidos por algum poder econômico ou político; 2) no caráter em que acaba implicando, numa visão utilitária da cultura, isto é, a cultura utilizada para servir a um domínio político." ${ }^{76}$

A figura do mecenas, citado pelo autor no primeiro aspecto, atravessou a história e permanece presente até hoje, embora de uma forma que não represente necessariamente um poder político ou econômico. ${ }^{77}$ A previsão legal para a prática do mecenato não é encontrada somente na legislação brasileira, como também na norteamericana, alemã e francesa. Fruto de uma política cultural que se inicia no governo do presidente José Sarney e se consolida no governo do presidente Fernando Henrique Cardoso, o legislador ordinário brasileiro, ao objetivar o incentivo de atividades culturais, permitiu expressamente a prática do mecenato por pessoas físicas ou jurídicas através de dedução no Imposto de Renda. O mecanismo do Mecenato está previsto na Lei no 8.313/91, conhecida como Lei Rouanet, que será estudada mais adiante.

Conforme visto no capítulo anterior, o direito fundamental à cultura necessita de uma prestação positiva do Estado que se realiza através da elaboração de políticas públicas para sua efetivação. Deve-se frisar seu uso no plural, uma vez que todos os entes federativos são responsáveis, em seus âmbitos, por elaborarem políticas culturais que não podem ignorar, em hipótese alguma, a participação da sociedade, sob o risco de se tornarem ilegítimas. Com a finalidade de esclarecer a postura que deverá ser adotada pelos poderes públicos e pela sociedade, será tomada como exemplo uma política cultural intitulada "Cidadania Cultural", que foi proposta por Marilena Chauí

\footnotetext{
76 Ibid. P. 12.

${ }^{77}$ Qualquer pessoa física pode patrocinar ou doar quantias a projetos culturais previamente aprovados pela Comissão Nacional de Incentivo à Cultura- CNIC. Dentre as entidades que exercem poderes políticos e econômicos no Brasil e atuam com frequência no papel de mecenas podemos destacar a Petrobrás, a Eletrobrás, a Vale, o Banco Itaú e o Banco Bradesco.
} 
quando Secretária de Cultura do Município de São Paulo durante o governo de Luiza Erundina (1989-1992):

"A Secretaria Municipal de Cultura não será produtora de cultura nem dirigirá a cultura sob perspectiva doutrinária. A esta Secretaria caberá estimular e promover as condições para que a população desta cidade crie e frua a invenção cultural. Sem dúvida, esta Secretaria, não tendo o monopólio das iniciativas culturais, terá o direito de receber, discutir, avaliar e propor objetos que Ihe venham da sociedade tanto quanto aqueles que venham de seus próprios funcionários, também participantes da vida cultural da cidade. Um sistema interno e externo de colegiados, fóruns e conselhos será desenvolvido com a finalidade de abrir o campo à participação dos cidadãos e dos funcionários cidadãos, na mudança de uma paisagem cultural de São Paulo." ${ }^{78}$

No âmbito federal, o Decreto no 91.144/1985, que criou o Ministério da Cultura- MinC, reconhece que "a situação atual do Brasil não pode mais prescindir de uma política nacional de cultura, consistente com os novos tempos e com o desenvolvimento já alcançado pelo País". Seguindo este mesmo sentido, o Regimento Interno do Ministério (o Anexo I do Decreto no. 6.835/2009) estabelece que a elaboração de uma política cultural nacional é de sua competência. Cabe agora responder ao título do presente subitem a partir da definição do professor Teixeira Coelho:

"Política cultural é entendida habitualmente como programa de intervenções realizadas pelo Estado, instituições civis, entidades privadas ou grupos comunitários com o objetivo de satisfazer as necessidades culturais da população e promover $o$ desenvolvimento de suas representações simbólicas. Sob este entendimento imediato, a política cultural representa-se assim como o conjunto de iniciativas, tomadas por esses agentes visando promover a produção, a distribuição e o uso da cultura, a preservação e divulgação do patrimônio histórico e o ordenamento do aparelho burocrático por elas responsável." 79

No caso das políticas públicas culturais, objeto de estudo do presente trabalho, tais iniciativas assumem a forma de normas jurídicas.

Teixeira Coelho reconhece aspectos importantes sobre as políticas culturais em geral. ${ }^{80}$ No tocante ao seu objeto podem ser dois: i) de caráter patrimonialista, dirigida para a preservação, fomento e difusão de tradições culturais autóctones ou ligadas às

${ }^{78}$ CHAUÍ, Marilena. Op. cit. p. 71.

${ }^{79}$ COELHO, Teixeira. Dicionário Crítico de Política Cultural. 3a Ed. São Paulo: Ed. lluminuras, 2004. P. 293

${ }^{80}$ Cf. Ibid. P. 296 e seg.. 
origens do país ("patrimônio histórico e artístico"). Engloba tanto o acervo da história das classes dirigentes quanto das classes populares; ii) criacionista, pois busca promover a produção, a distribuição e o uso e consumo de novos valores e obras culturais. Neste último, o autor critica sua tendência elitista, uma vez que costumam privilegiar a cultura das elites (e.g. catedrais barrocas e partituras de música erudita).

No que tange aos seus circuitos de intervenção, as políticas culturais podem ser de cinco tipos básicos: i) políticas relativas ao mercado cultural que apóiam setores de produção, distribuição e consumo da cultura; ii) políticas relativas à iniciativa privada no campo da cultura que definem incentivos fiscais e regras para a prática do mecenato, citada anteriormente; iii) políticas relativas à cultura alheia ao mercado cultural, pois buscam proteger grupos folclóricos, de cultura popular e de amadores, observando-se, assim, a preservação do patrimônio cultural brasileiro; iv) políticas relativas aos usos da cultura que se ocupam com a criação de condições para que os cidadãos possam exercer seus direitos culturais (e.g. centros de cultura, cursos, seminários, ateliês, etc.); v) políticas relativas às instâncias institucionais dos circuitos culturais que visam à organização administrativa da cultura.

No Brasil pode-se afirmar que o início da elaboração de uma política pública cultural efetiva se deu a partir da década de 1930, durante a Era Vargas. Foi neste período histórico que foi iniciado um processo de institucionalização da cultura, tendo como pano de fundo uma reforma administrativa que buscou elaborar políticas específicas de âmbito nacional a serem implementadas em diferentes setores, conforme será estudado no próximo subitem.

\subsection{2. -As Políticas Culturais no Brasil: da Era Vargas ao Mandato de Fernando Henrique Cardoso.}

Embora a relação entre política e cultura fosse debatida desde a Proclamação da República por autores do calibre de Euclides da Cunha, Lima Barreto e, posteriormente, Monteiro Lobato, reconhece-se que o embrião da formulação de uma 
política pública cultural foi a criação do Departamento de Cultura do Município de São Paulo. Fundado, em 1935, pelo então prefeito Fábio da Silva Prado, teve como seu diretor Mário de Andrade, participante do movimento modernista da década de 1920 e prestigiado intelectual brasileiro. Os objetivos do Departamento de Cultura de São Paulo, delineados no artigo 1으, Título I do Ato no 861 eram, entre outros, "estimular e desenvolver todas as iniciativas destinadas a favorecer o movimento educacional, artístico e cultural", criar e organizar bibliotecas públicas para a difusão da cultura entre todas as camadas da população e proteger e publicar documentações referentes à história da cidade de São Paulo. ${ }^{81}$

Seus projetos, que eram considerados à sua época como avançados, modernos, a par do desenvolvimento europeu e que buscavam a democratização da cultura, tiveram como frutos a Discoteca Pública, a construção de um novo prédio para a Biblioteca Municipal em estilo art déco, a aquisição das bibliotecas de Félix Pacheco e de Alberto Lamego, pesquisas folclóricas, a restauração de documentos quinhentistas, a descoberta de relíquias a serem tombadas pelo Patrimônio Histórico Artístico e Nacional, a criação do Coral Paulistano, entre outros. ${ }^{82}$

Para Martin Cezar Feijó, o principal aspecto da política cultural adotada pelo modernista foi a tentativa de relacionamento entre diferentes culturas:

"A grande preocupação de Mário de Andrade era a de aproximar a "cultura popular" da "cultura erudita". (...) O incentivo do acesso erudito à cultura popular (e vice-versa) visava exatamente democratizá-la. Democratizar seria, então, aproximar culturas; não isolá-las." ${ }^{83}$

Mário de Andrade, juntamente com Paulo Duarte, um dos fundadores da Universidade de São Paulo (USP), vislumbrava no Departamento de Cultura do Município de São Paulo a possibilidade de conceber o Instituto Paulista de Cultura que, em nível Estadual, englobaria o próprio Departamento, bem como o Departamento do Patrimônio Histórico e Artístico de São Paulo. Em um momento posterior, seria fundado o Instituto Brasileiro de Cultura. Tal ideia viria a se tornar um dos

\footnotetext{
${ }^{81}$ DASSIN, Joan. Política e Cultura em Mário de Andrade. São Paulo: Ed. Duas Cidades, 1978. P. 106.

${ }^{82}$ Ibid. P. 104 a 106.

${ }^{83}$ FEIJÓ, Martin Cezar. Op. cit. P. 54.
} 
fundamentos do Decreto-Lei no 25 de 1937, que criou o Serviço do Patrimônio Histórico Nacional - SPHAN. Entretanto, com a outorga da Constituição de 1937 instalou-se o Estado Novo, que teve como figura principal o ditador Getúlio Vargas. Neste mesmo ano, Vargas nomeou para interventor de São Paulo Prestes Maia, destituindo, assim, o então prefeito Fábio Prado. Em maio de 1938, Mário de Andrade, insatisfeito, abre mão de seu cargo político.

Enquanto ainda era diretor do Departamento de Cultura de São Paulo, Mário de Andrade foi requisitado pelo então Ministro da Educação e da Saúde, Gustavo Capanema, para elaborar um anteprojeto de lei que criaria o Serviço do Patrimônio Artístico Nacional - SPAN, quatro livros de Tombamento e quatro Museus, e definiria o Patrimônio Artístico Nacional. ${ }^{84}$ Entretanto, somente parte dele foi aproveitada quando da edição do Decreto-Lei no 25, de 30 de novembro de 1937, que se encontra em vigor até hoje com poucas alterações, cujo grande mérito foi a criação do instituto de caráter administrativo para tutelar o "patrimônio artístico e histórico" denominado tombamento, objeto de estudo do próximo item. Para o desenhista e pintor Alcides da Rocha Miranda, um dos responsáveis pela implementação do Serviço do Patrimônio Histórico e Artístico Nacional - SPHAN, o anteprojeto de Mário de Andrade era "uma coisa imensa, tão grande, que era difícil de fazer funcionar, porque não havia verbas suficientes, não havia elementos humanos com conhecimento e prática para poder exercer". ${ }^{85}$ Ademais, o anteprojeto continha proteção a bens imateriais, inovação total à época, bem como confrontava o projeto de unidade nacional e construção de uma

\footnotetext{
${ }^{84}$ A definição de Patrimônio Artístico Nacional de Mario de Andrade é bastante ampla: "entende-se por Patrimônio Artístico Nacional todas as obras de arte pura ou arte aplicada, popular ou erudita, nacional ou estrangeira, pertencentes aos poderes públicos, a organismos sociais e a particulares nacionais, a particulares estrangeiros, residentes no Brasil." (ANDRADE, Mario de. Anteprojeto para a criação do Serviço do Patrimônio Artístico Nacional. In: BATISTA, Marta Rossetti (org.). Revista do Patrimônio Histórico e Artístico Nacional, no 30. Brasília: Instituto do Patrimônio Histórico e Artístico Nacional IPHAN, 2002. P.272). No Patrimônio Artístico Nacional estariam incluídos, depois de inscritos em algum dos quatro livros de Tombamento, manifestações culturais especificadas em objetos, monumentos, paisagens e folclore.

${ }^{85}$ MIRANDA, Alcides da Rocha. Entrevista. In: BATISTA, Marta Rossetti (org.). Op. Cit. P. 247.
} 
cultura nacional oficial durante o governo de Vargas. ${ }^{86}$ Na visão de Sérgio Luiz Dias Portella,

"Estamos diante do patrimônio antropofágico de Mário, que tudo devora, regurgita, e vomita novo, irreconhecível. A ironia é que é justamente a ciência criada para estudar as tribos, os índios - antropófagos ou não - que acaba por instrumentalizar essa antropofagia do patrimônio. São os conceitos advindos da antropologia que permitem a Mário transformar todas as manifestações socioculturais em patrimônio artístico." 87

O autor da presente monografia acredita que os ecos do patrimônio artístico de Mário de Andrade encontram-se presentes hoje na Constituição Federal de 1988, quando define o que é patrimônio cultural brasileiro. Um legítimo patrimônio cultural abaporu.

Com fulcro na previsão constitucional de que caberia à União proteger os objetos de interesse histórico e o patrimônio artístico do país (artigo 148 da Constituição Federal de 1934), o SPHAN foi criado através da Lei no 378 de 13 de janeiro de 1937, estipulando sua subordinação ao Ministério da Educação e Saúde MES. Seu primeiro presidente foi o escritor, jornalista, pesquisador e advogado Rodrigo Melo Franco de Andrade, que permaneceu no cargo até 1967. O órgão, em seu início, contou com a contribuição de renomados profissionais de diferentes áreas do saber, dentre eles Lucio Costa, Afonso Arinos, Mario de Andrade e Carlos Drummond de Andrade. Estes trinta anos compõem a denominada "fase heróica" da instituição, tendo em vista todas as dificuldades encontradas neste período para efetivar o tombamento de bens, sobretudo daqueles que se encontravam na esfera privada. Em seu primeiro momento, a preocupação maior do SPHAN foi, essencialmente, o tombamento de bens do período colonial brasileiro. Segundo uma visão mais crítica, a política do SPHAN foi reduzida à preservação arquitetônica dos monumentos de "pedra e cal" relacionados à

\footnotetext{
${ }^{86}$ Cf. CALABRE, Lia. Políticas Culturais no Brasil: dos anos 1930 ao século XXI. Rio de Janeiro: Ed. FGV, 2009. P. 22.

87 PORTELLA, Sérgio Luiz Dias. Patrimônio antropofágico: AM reflete MA. In: CALABRE, Lia. Políticas culturais: diálogo indispensável. Rio de Janeiro: Edições Casa de Rui Barbosa, 2005. P. 24.
} 
experiência vitoriosa da etnia branca, às experiências vitoriosas da religião católica, no Estado e na sociedade, e da elite política e econômica do Brasil. ${ }^{88}$

Sua criação não foi um ato administrativo isolado. Deve-se levar em consideração seu contexto. Após a Revolução de 1930, liderada por Getúlio Vargas, iniciou-se uma reforma e ampliação do aparelho estatal, o que acarretou na legalização, institucionalização e sistematização na vida política e cultural do país ${ }^{89}$, que começava a firmar-se dentro de um modelo urbano-industrial. Naquele mesmo ano foi criado o Ministério da Educação e Saúde Pública ${ }^{90}$, pasta pela qual, em 1934, tomou posse o advogado mineiro Gustavo Capanema. Foi durante seu período à frente do Ministério da Educação e Saúde que, cercado por uma verdadeira "constelação" de nomes que incluía Heitor Villa-Lobos, Anísio Teixeira, Mario de Andrade e Manuel Bandeira, acentuou-se a interferência estatal no campo da cultura, conforme sublinhado por Cecília Londres:

"[o campo da cultura] não era uma prioridade do ministro no momento de sua nomeação, em 1934, quando em seu discurso de posse, deu destaque à educação nacional, à saúde pública e à assistência social. Mas no decorrer dos 11 anos que ficou à frente da pasta, praticamente não houve setor da cultura que tenha escapado de sua atenção, desde a radiodifusão e o cinema ao decisivo apoio prestado à arquitetura e às artes plásticas contemporâneas. Nesse período foram criados vários museus nacionais - Museu Nacional de Belas Artes, Museu Imperial, Museu da Inconfidência - e, no âmbito do Serviço do Patrimônio Histórico e Artístico Nacional (SPHAN), inúmeros museus regionais e casas históricas. Capanema fez, inclusive, incursões em áreas como o artesanato e a questão indígena. Terminada sua gestão, estava esboçado o desenho básico da organização institucional da cultura no Estado brasileiro e plantado o embrião do que, em 1981, veio a se constituir na Secretaria de Cultura do MEC e, em 1985, no Ministério da Cultura. É razoável supor que Capanema tenha-se dado conta do alcance de sua obra, pois chegou a dizer ao presidente Getúlio Vargas que sua pasta poderia denominar-se Cultura Nacional." ${ }^{91}$

Ressalta-se que as políticas culturais do governo de Getúlio Vargas contemplaram diferentes demandas setoriais nunca antes atendidas pelo Estado

\footnotetext{
${ }^{88}$ Cf. FALCÃO, Joaquim Arruda. Política Cultural e Democracia: A preservação do Patrimônio Histórico e Artístico Nacional. In: MICELI, Sérgio (org.). Estado e Cultura no Brasil. São Paulo: Ed. Difel, 1984. P. 28.

${ }^{89}$ Ibid. P. 26.

${ }^{90}$ Em 1937 o ministério foi renomeado para Ministério da Educação e Saúde - MES.

${ }^{91}$ LONDRES, Cecília. A Invenção do Patrimônio e a Memória Nacional. In: BOMENY, Helena (org.). Constelação Capanema: Intelectuais e Políticas. Rio de Janeiro: Ed. FGV, 2001. P. 85-86.
} 
brasileiro através da criação de órgãos oficiais. No setor cultural, foram criados o Instituto Nacional de Cinema Educativo - INCE (1937), o Serviço Nacional de Teatro SNT (1937), o Departamento de Propaganda e Difusão Cultural - DPDC (1934), o Instituto Nacional do Livro - INL (1937) e o Conselho Nacional de Cultura - CNC (1938).

A época compreendida entre o fim da ditadura de Vargas e a instauração da Ditadura Militar (1945-1964) é marcada pela diminuição da interferência do Estado no âmbito cultural, ao passo que as iniciativas culturais desenvolveram-se através de um intenso investimento por parte da iniciativa privada em um quadro de progressivo fortalecimento dos meios de comunicação de massa, que se tornaram mais acessíveis pela população. Foi no cenário do desenvolvimento urbano-industrial brasileiro que a indústria cultural inicia seu processo de consolidação através do rádio, da televisão e do cinema. Deve ser lembrado que neste período surgiram manifestações culturais de riqueza e importância para o país como, por exemplo, a Bossa Nova, o Cinema Novo, o Concretismo, os grupos de teatro Arena e Oficina, e o Centro Popular de Cultura da UNE.

Embora a maior parte das ações culturais do Estado neste período histórico "se restringia a regulamentar e dar continuidade às instituições que foram criadas ao longo do Governo Vargas" ${ }^{92}$, destaca-se o surgimento das seguintes instituições: o Instituto Brasileiro de Educação, Ciência e Cultura - Ibecc (1946), que incluía a Comissão Nacional de Folclore - CNFL; o Ministério da Educação e Cultura - MEC (1953); o Instituto Superior de Estudos Brasileiros - ISEB (1955) e a aprovação do regimento do Serviço Nacional de Teatro - SNT (1958).

Durante o governo de Juscelino Kubistchek (1956-1960), o setor cultural recebeu poucos investimentos do Estado uma vez que "estabeleceu outras prioridades de aplicação de recursos para o país." ${ }^{93}$ O quadro começa a ser alterado durante o governo de Jânio Quadros quando foi promulgado o Decreto no 50.293, de 23 de fevereiro de 1961, que criou o Conselho Nacional de Cultura - CNC, um órgão

\footnotetext{
92 CALABRE,Lia. Op. Cit. P. 45.

${ }^{93}$ Ibid. P. 64.
} 
subordinado diretamente à Presidência da República e que não possuía qualquer relação com aquele criado em 1938 durante a gestão de Gustavo Capanema. Dentre suas atribuições elencadas no artigo 3o do decreto que o instituiu, destaca-se que cabia ao CNC "estabelecer a política cultural do Governo, mediante plano geral a ser elaborado, e programas anuais de aplicação.". Após a renúncia de Jânio Quadros à presidência, o CNC foi subordinado ao MEC, do mesmo modo que era no período Vargas. Frisa-se que o órgão, desde sua criação, esbarrava em dificuldades orçamentárias para que suas políticas fossem efetivadas. Evidenciou-se que o Estado não aplicou o dinheiro público na área cultural por mera falta de interesse, fato este que se tornaria corriqueiro nos anos seguintes. Deve ser destacada a principal ação cultural do CNC, idealizada pelo seu presidente, o embaixador Paschoal Carlos Magno: a realização do projeto "Caravana da Cultura”, que, entre os anos de 1963 e 1964, percorrendo os estados do Rio de Janeiro, Minas Gerais, Bahia, Sergipe e Alagoas, promoveu apresentações musicais, exposições e a distribuição de livros e discos à população, sempre acompanhadas por orientações e debates promovidos por professores.

Após o golpe militar de 1ำ de abril de 1964, nas palavras de Lia Calabre, "o país passa a viver um período de repressão e censura que resultou no desmantelamento da grande maioria dos projetos culturais em curso". 94 Octavio lanni, em artigo escrito no ano de 1978, aprofunda sobre o tema quando analisa a postura adotada pelo governo militar, que se utilizou da censura como método de reprimir e cercear a produção cultural daquele período:

"Nos anos 1964-1978, o Estado Brasileiro foi colocado no centro da produção cultural do país. Mais do que isso, praticamente todas as condições de produção, comunicação e debate das produções artísticas e científicas (quanto a estas, refiro-me ao campo das ciências sociais) passaram a ser controladas ou influenciadas pelos ministérios, conselhos, comissões, institutos ou outros órgãos do Estado. A televisão, a rádio, o jornal, a revista, a editora, a escola, o teatro, o cinema, a música, todas as esferas da criação e debate culturais acham-se sob controle ou influência do poder estatal; por estímulo, tolerância ou censura." ${ }^{95}$

\footnotetext{
${ }^{94}$ Id. Política cultural no Brasil: um breve histórico. In: CALABRE, Lia. Op. Cit. P.11.

95 IANNI, Octavio. O Estado e a Organização da Cultura. In: Encontros com a Civilização Brasileira. №1. Rio de Janeiro: Ed. Civilização Brasileira, 1978. P. 229-230.
} 
A partir deste determinado ponto tornou-se notável que "o Estado foi levado a desenvolver uma vasta e complexa organização cultural, que permeia o conjunto da sociedade civil, em suas instituições ou grupos e classes sociais" ${ }^{96}$, que foi iniciada em 1966, durante o governo do marechal Humberto Castello Branco. Neste ano foram criados o Conselho Federal de Cultura - CFC, através do Decreto-Lei no 74, e o Instituto Nacional de Cinema - INC, através do Decreto-Lei no 43. Ao primeiro, que contava com 24 membros indicados pelo Presidente da República, cabia, dentre outros deveres, formular a política cultural nacional, embora não tenham se registrado avanços concretos $^{97}$ e ensejar a criação e desenvolvimento dos Conselhos Estaduais de Cultura. Seu presidente no período de 1968 a 1973, Arthur Reis, tentou diversas vezes implementar, sem sucesso, o Plano Nacional de Cultura que conteria as diretrizes a serem tomadas pelas ações do Estado no setor. Já ao INC, que incorporou o INCE do governo Vargas, cabia, dentre outras competências previstas no artigo 4음 do DecretoLei que o instituiu, "regular e executar a política governamental relativa ao desenvolvimento da indústria cinematográfica brasileira, ao seu fomento cultural e à sua promoção no exterior."

Ainda no campo do audiovisual, em 12 de setembro de 1969, foi criada por meio do Decreto-Lei no 862 uma pessoa jurídica de direito privado e vinculada ao MEC denominada Empresa Brasileira de Filmes S.A. - Embrafilme. Ela foi essencial para a industrialização e fortalecimento do mercado cinematográfico brasileiro nas décadas de 1970 e 1980, ocupando o posto de maior produtora e distribuidora do período, conforme salientado pela pesquisadora Melina Izar Marson:

"Durante mais de duas décadas de atuação, entre 1969 e 1990, a Embrafilme foi responsável pela regularidade da produção do cinema do Brasil, por meio do financiamento da produção, da garantia da exibição (pela obrigatoriedade instituída via cota de tela para o produto nacional) e da distribuição dos filmes brasileiros. Além disso, em seu período mais produtivo, a Embrafilme ajudou a proporcionar o encontro

\footnotetext{
${ }^{96}$ Ibid. p. 231.

${ }^{97}$ Cf. CALABRE, Lia. Op. Cit. P. 12.
} 
do filme nacional com o público, durante meados dos anos 70 e início dos anos 80, quando o cinema bateu recordes de público (...)" ${ }^{\prime 98}$

Em 1970, via Decreto no 66.967, foi criado o Departamento de Assuntos Culturais (DAC), órgão central de direção superior que manteve sob sua vinculação o agora denominado Instituto do Patrimônio Histórico e Artístico Nacional - IPHAN, que passou a ser dotado de maior autonomia administrativa e financeira se comparado ao seu quadro prévio. Ao CFC, agora órgão normativo do MEC, coube função consultiva, enquanto ao DAC coube a função executiva. Foi na gestão do então ministro Jarbas Passarinho (1969-1973) que se deu o primeiro passo para a elaboração pelo CFC de diretrizes para uma política nacional de cultura, aproveitadas para a Política Nacional de Cultura, aprovada em 1975. Esta, por sua vez, foi aprovada durante a gestão do Ministro Ney Braga (1974-1978).

Durante o período de Ney Braga à frente do MEC, ocorreu um notável avanço no que diz respeito às políticas públicas culturais, decorrentes do discurso de distensão institucional e política do governo do presidente Ernesto Geisel. Além da aprovação da citada Política Nacional de Cultura, de extrema relevância ${ }^{99}$, foram criados o Conselho Nacional de Direito Autoral - CNDA, o Conselho Nacional de Cinema - CONCINE, a Fundação Nacional de Arte - FUNARTE, o Centro Nacional de Referência Cultural CNRC, a campanha da Defesa do Folclore Brasileiro e a Secretaria de Assuntos Culturais - SEAC. Em 1979, durante a curta gestão de Eduardo Portella frente ao MEC, o IPHAN foi desmembrado em dois: Secretaria do Patrimônio Histórico e Artístico Nacional (SPHAN), incumbido de ser um órgão normativo; e a Fundação Nacional Pró-Memória (Pró-Memória), órgão de caráter executivo para a efetiva proteção do patrimônio

\footnotetext{
${ }^{98}$ MARSON, Melina Izar. Cinema e Políticas de Estado: da Embrafilme à Ancine. São Paulo: Escrituras Editora, 2009. P. 18.

${ }^{99}$ Segundo Sérgio Micelli, "a importância político-institucional deste "ideário de uma conduta" consistiu sobretudo no fato de haver logrado inserir o domínio da cultura entre as metas da política de desenvolvimento social do governo Geisel. Foi a única vez na história republicana que o governo formalizou um conjunto de diretrizes para orientar suas atividades na área cultural, prevendo ainda modalidades de colaboração entre os órgãos federais e de outros ministérios (...)" (MICELI, Sérgio. O Processo de "Construção Institucional" na área da cultura federal (anos 70). In: MICELI, Sérgio (org.). Op. Cit. P. 57. Ressalva-se que o mesmo foi feito durante o governo Lula quando da aprovação do Plano Nacional de Cultura - PNC.
} 
histórico e artístico nacional. O ilustre designer gráfico Aloísio Magalhães foi nomeado para ser diretor de ambos os órgãos.

A gestão de Rubem Ludwig (1980-1982) pouco alterou a estrutura funcional da cultura. Destaca-se a criação da Secretaria de Cultura - SEC, resultado da fusão entre a SEAC e o IPHAN, sendo Aluisio Magalhães nomeado Secretário de Cultura, cargo que exerceu até sua morte, em 1982. Logo após, tomou posse o advogado pernambucano Marcos Vilaça. Também, a partir de 1981, ficaram vinculados à SEC a Pró-Memória, o INL, a Biblioteca Nacional, o Museu Histórico Nacional, o Museu Imperial, o Museu Nacional de Belas Artes, o Museu Villa-Lobos, o Museu da República e o Serviço Nacional de Teatro. Ainda assim, a Secretaria contava com um baixo orçamento, questão de longa data e presente até hoje.

Paralelamente, nos âmbitos regionais e locais, o setor cultural foi sendo fortalecido e institucionalizado através da firmação das Secretarias de Cultura, desde o final da década de 1970. Os Secretários de Cultura dos Estados do Rio de Janeiro, São Paulo, Paraná e Minas Gerais deram o primeiro passo para a criação de um Ministério da Cultura quando se reuniram na cidade de Ouro Preto em março de 1983. Desta reunião saiu a ideia de realizar de modo permanente um Fórum Nacional de Secretários da Cultura. A primeira edição, liderada por José Aparecido de Oliveira, então Secretário de Cultura do Estado de Minas Gerais, ocorreu em novembro do mesmo ano em Curitiba. As principais reivindicações das seis primeiras edições do Fórum, que ocorreram até 1985, versavam sobre o aumento da proteção ao patrimônio histórico e artístico e da participação orçamentária da cultura; a criação do Fundo Federal do Desenvolvimento da Cultura; e a implementação do Ministério da Cultura. Lia Calabre descreve esta última reivindicação:

"Uma das posições defendidas pelo Fórum Nacional de Secretários de Cultura era a criação do Ministério da Cultura, tema sem apoio por parte dos funcionários e dos técnicos da área de cultura do MEC, que temiam pela fragilidade da área. A problemática da criação de um ministério específico pela cultura havia sido muito debatida e defendia pelo Conselho Federal de Cultura na década de 1970, que também incentivava os estados e municípios a criarem estruturas autônomas." 100

${ }^{100}$ CALABRE, Lia. Op. Cit. P. 99. 
Os Secretários de Cultura lograram êxito em março de 1985, quando do término do período autoritário que o Brasil vivenciava. O presidente que tomou posse, José Sarney, que já havia demonstrado sensibilidade quanto à prioridade que deveria ser dada à cultura em seu governo, criou o Ministério da Cultura - MinC. Através do Decreto $\mathrm{n}$ - 91.144, de 15 de março de 1985, foram consubstanciados os argumentos expostos desde os anos 1970 no sentido de que o Ministério da Educação e Cultura era, nas palavras contidas no próprio texto legal, "incapaz de cumprir, simultaneamente, as exigências dos dois campos de sua competência na atualidade brasileira" diante das transformações ocorridas nas duas décadas que prescindiram sua criação nas quais se tinham "exigido políticas específicas bem caracterizadas, a reclamarem o desmembramento da atual estrutura unitária em dois ministérios autônomos". Defronte deste quadro, tornou-se imprescindível a elaboração de uma política cultural nacional pelo Ministério da Cultura.

O primeiro Ministro da Cultura foi José Aparecido de Oliveira, que logo renunciou, dando espaço a Aluisio Pimenta. Em 1986, tomou posse o economista Celso Furtado, reconhecido como "o primeiro ministro que buscou, efetivamente, promover a estruturação do necessário para o funcionamento do MinC". ${ }^{101}$ Neste primeiro momento, no qual muitos obstáculos foram enfrentados, principalmente os de ordem financeira e política, estavam vinculados ao Ministério o Conselho Federal de CulturaCFC, o Conselho Nacional de Direitos Autorais - CNDA, o Conselho Nacional de Cinema CONCINE, a Secretaria de Cultura, a Embrafilme, a Funarte, a Pró-Memória, a Fundação Casa de Rui Barbosa e a Fundação Joaquim Nabuco. Foram criados o Instituto Nacional de Artes Cênicas - IACEN, a Secretaria do Patrimônio Histórico e Artístico Nacional SPHAN, a Secretaria de Atividades Socioculturais - SEAC, a Secretaria de Difusão e Intercâmbio - SEDI e a Secretaria de Apoio Cultural - SEAP.

Seguindo a esteira neoliberal do governo, durante a gestão de Celso Furtado foi aprovada a Lei no 7.505, de 2 de julho de 1986, conhecida como Lei Sarney. Proposta

101 Ibid. P. 100. 
da década de 1970 pelo então senador José Sarney, foi a primeira lei a permitir concessão de benefícios fiscais para contribuintes (pessoas físicas ou jurídicas) através de doações, patrocínios ou investimentos, definindo seus campos de abrangência, que deveriam ser realizados através ou em favor de pessoas jurídicas de natureza cultural, com ou sem fim lucrativos, desde que cadastradas no Ministério da Cultura. Criou-se, destarte, a previsão legal da prática do mecenato: o contribuinte poderia abater de sua renda bruta ou deduzir com despesa operacional o valor doado, patrocinado ou investido, respeitados os limites previstos para a modalidade praticada. No entendimento da pesquisadora Cristiane Garcia Olivieri, a Lei Sarney foi criada "com a intenção de disponibilizar mais verbas para custeio das produções culturais, permitindo que o próprio mercado realizasse a escolha da atividade cultural que seria patrocinada." 102 A lei também criou o Fundo de Promoção Cultural, gerido pelo MinC, para corrigir as distorções que iriam certamente ser ocasionadas, principalmente no que diz respeito às desigualdades de âmbito regional. Todavia, diante da pequena dotação orçamentária do Fundo de Promoção Cultural, da ausência de transparência envolvendo seus recursos aplicados e da fraca fiscalização por parte da administração pública, a Lei Sarney não foi capaz de concretizar plenamente seu objetivo. Lia Calabre fez um balanço do período em que a lei em comento esteve em vigor, até março de 1990, quando foi extinta no meio de acusações de favorecimento ao clientelismo e à corrupção no meio cultural:

"Em todo o período que esteve vigente, a Lei Sarney foi objeto de muitas críticas, principalmente no que diz respeito à falta de transparência na aplicação de recursos e, também, por criar um grupo privilegiado de empresas cadastradas. [...] Entretanto, mesmo com todas as críticas, os analistas reconhecem que ocorreu um processo de ampliação no volume das produções artísticas e culturais, mas que estavam longe de alcançar o objetivo inicial que era o de promover a democratização cultural tanto no acesso quando na produção." 103

Fernando Collor de Mello foi o primeiro presidente eleito de forma democrática após quase trinta anos. Ao assumir a Presidência da República em janeiro de 1990, sua

102 OLIVIERI, Cristiane Garcia. Op. Cit.. P. 71.

103 Ibid. P.102-203. 
postura política neoliberal refletiu-se no setor cultural ao compreender que nele não deveria caber intervenção do Estado. A cultura, portanto, deveria ser um "problema de mercado", no qual deveriam ser excluídas as responsabilidades estatais no setor. Portanto, "a produção cultural passou a ser vista como qualquer outra área produtiva que deve se sustentar sozinha através de sua inserção no mercado." 104 O governo Collor representou uma brusca ruptura no que diz respeito à construção das políticas culturais que vinha ocorrendo desde os anos 1930. O orçamento da Secretaria foi reduzido em $50 \%$ se comparado ao da gestão anterior. Por via das Leis $n \circ 0.028$ e $n$ 은 8.029, ambas de 12 de abril de 1990, o Ministério da Cultura, principal conquista do Fórum Nacional de Secretários de Cultura, foi transformado em Secretaria da Cultura, órgão de assistência direta e imediata ao Presidente da República. ${ }^{105}$ Foram extintos a Embrafilme ${ }^{106}$, o Concine, a Funarte, a Fundacen, a Fundação do Cinema Brasileiro, a Fundação Pró-memória e a Fundação Nacional Pró-Leitura. Por outro lado, foram criados o Instituto Brasileiro de Artes e Cultura - IBAC, que possuía quadro profissional e receita oriundos da Funarte, a Fundacen e a Fundação do Cinema Brasileiro; e o Instituto Brasileiro de Patrimônio Cultural - IBCP, que englobou a Secretaria do Patrimônio. Acrescenta-se que a Fundação Pró-Memória foi englobada pela Fundação Biblioteca Nacional.

O primeiro Secretário da Cultura do mandato de Collor foi o cineasta Ipojuca Pontes, muito criticado e rejeitado pelos intelectuais e pela classe artística no período de sua gestão. Em 1991 tomou posse Paulo Sérgio Rouanet, renomado filósofo, antropólogo e diplomata brasileiro, mais compassivo em relação às questões condizentes ao setor cultural e com maior aceitação no meio intelectual e artístico. Retomando as políticas públicas culturais e atendendo a principal reivindicação das

\footnotetext{
${ }^{104}$ MARZON, Melina Izar. Op. Cit. P. 17.

${ }^{105}$ A extinção do MinC acarretou na extinção do Conselho Federal de Cultura - CFC e do Conselho Federal de Cinema - Concine.

${ }^{106}$ A extinção da Embrafilme causou uma crise sem precedentes ao setor cinematográfico brasileiro, acostumado com uma atuação "paternalista" do Estado, conforme pode-se observar em 1992, ano pelo qual foram lançados apenas três filmes . Sua recuperação, conhecida como "A Retomada", cujo primeiro sucesso foi a obra "Carlota Joaquina, a Princesa do Brazil" (1995), se deu através da edição Lei do Audiovisual, em 1993.
} 
classes artística e intelectual, no mesmo ano foi aprovada a Lei № 8.313, de 23 de dezembro de 1991, hoje regulamentada pelo Decreto no 5.761/2006, popularmente conhecida Lei Rouanet, que manteve alguns princípios básicos da Lei Sarney. Contudo, coube agora ao Estado aprovar previamente os projetos a serem incentivados com a finalidade de prevenir eventuais fraudes à guisa do ocorrido durante a vigência da Lei Sarney. A Lei Rouanet criou o Programa Nacional de Apoio à Cultura - PRONAC ${ }^{107}$, que constituiu três mecanismos para o fomento à cultura: o Fundo Nacional da Cultura FNC, os Fundos de Investimento Cultural e Artístico - FICARTs e o Mecenato.

Após o impeachment de Fernando Collor de Mello, em outubro de 1992, tomou posse o vice-presidente Itamar Franco. Logo que assumiu, restabeleceu o Ministério da Cultura e seus órgãos. A Funarte e o IPHAN voltaram a ser vinculados ao MinC, enquanto a Embrafilme, o Concine e o CNDA não tiveram o mesmo destino: permanecem extintos até hoje. Foram instituídos o Conselho Nacional de Política Cultural, órgão de assessoria direta ao Ministro da Cultura, cuja finalidade é a proposição de políticas públicas para o desenvolvimento e fomentos das atividades culturais e a Secretaria para o Desenvolvimento do Audiovisual; como também foi realizada a primeira Comissão Nacional de Incentivo Cultural - CNIC, órgão vinculado ao MinC com representantes do Estado e da Sociedade Civil cuja competência é aprovar os projetos culturais, conforme o previsto no artigo 32 da Lei Rouanet.

Por intermédio de pressões oriundas do setor cinematográfico, ainda no governo de Itamar Franco, entrou em vigor a Lei no 8.685, de 20 de julho de 1993, conhecida como a Lei do Audiovisual. O Estado retomou para si o papel de

\footnotetext{
107 De acordo com o artigo 10 da Lei Rouanet, o PRONAC possui a finalidade de "captar e canalizar recursos para o setor de modo a: I - contribuir para facilitar, a todos, os meios para o livre acesso às fontes da cultura e o pleno exercício dos direitos culturais; II - promover e estimular a regionalização da produção cultural e artística brasileira, com valorização de recursos humanos e conteúdos locais;ill apoiar, valorizar e difundir o conjunto das manifestações culturais e seus respectivos criadores; IV proteger as expressões culturais dos grupos formadores da sociedade brasileira e responsáveis pelo pluralismo da cultura nacional; $V$ - salvaguardar a sobrevivência e o florescimento dos modos de criar, fazer e viver da sociedade brasileira; VI - preservar os bens materiais e imateriais do patrimônio cultural e histórico brasileiro; VII-desenvolver a consciência internacional e o respeito aos valores culturais de outros povos ou nações; VIII-estimular a produção e difusão de bens culturais de valor universal, formadores e informadores de conhecimento, cultura e memória; IX-priorizar o produto cultural originário do País."
} 
patrocinador de obras cinematográficas, o que consequentemente representou o resgate do cinema nacional após um breve, porém intenso, período obscuro. Nas palavras de Melina Izar Marzon, "com a volta do patrocínio estatal e a aprovação da Lei do Audiovisual, o campo cinematográfico se agitou, e novos filmes começaram a ser produzidos." 108

O governo do presidente Fernando Henrique Cardoso, iniciado em 1995 e estendido até 2002, deu continuidade à política neoliberal baseada na teoria do Estado Mínimo iniciada por Collor. O campo da cultura foi marcado pela firmação do Ministério da Cultura e consolidação do incentivo fiscal como principal política cultural. Francisco Weffort foi o titular da pasta até o término do mandato do presidente, o que significou uma continuidade das políticas culturais, se comparado com as constantes trocas dos Secretários e Ministros da Cultura que o antecederam. Em sua gestão, o número de empresas que utilizaram o incentivo fiscal cresceu vertiginosamente. 0 professor Antonio Albino Canelas Rubim reconhece que a política cultural calcada nas leis de incentivo fiscal, que privilegia o mercado por via da utilização de dinheiro público gerido por empresas privadas, não é salutar:

"A cruel combinação entre a escassez de recursos estatais e a afinidade dessa lógica de financiamento com os ideários neoliberais então vivenciados no mundo e no país fez com que uma parcela considerável dos criadores e dos produtores culturais passasse a identificar política de financiamento e, pior, políticas culturais tão somente com as leis de incentivo. A profunda sedimentação e a admirável persistência desse imaginário de inspiração neoliberal em parcelas significativas do campo cultural irão empobrecer a imaginação e as alternativas de políticas culturais no Brasil. Outra vez mais a articulação entre democracia e políticas culturais se mostrava problemática. O Estado persistia em sua ausência no campo cultural em tempos de democracia. (...) No governo FHC - Francisco Weffort, essa nova modalidade de ausência atinge seu ponto culminante." 109

Neste mesmo sentido, Lia Calabre afirma que o critério de aprovação de projetos culturais utilizado pela CNIC durante a gestão de Weffort, limitado à verificação legal dos objetivos dos mesmos,

\footnotetext{
${ }^{108}$ MARSON, Melina Izar. Op. Cit. 57.

${ }^{109}$ RUBIM, Antonio Albino Canelas. Políticas Culturais no Brasil: Itinerários e atualidade. In: BOLAÑO, César et al. (org.). Economia da Arte e da Cultura. São Paulo: Itaú Cultural, 2010. P. 61.
} 
"fez com que efetivamente o mercado decidisse em quais projetos deveria investir, quais renderiam a desejada imagem de marketing cultural. $O$ que o governo terminou fazendo foi liberar recursos públicos para serem aplicados sob a ótica do interesse empresarial." 110

As gestões dos Ministros da Cultura Gilberto Gil (2003-2008) e Juca Ferreira (2008-2010), período no qual há um movimento do próprio Ministério da Cultura no sentido de reformular este quadro de políticas culturais, serão analisadas no terceiro capítulo.

No próximo item serão discorridos os principais instrumentos para a efetivação do direito fundamental à cultura.

\section{2 - A Efetivação do Direito Fundamental à Cultura.}

\subsection{1 - Mecanismos para o Fomento e Custeio da Produção Cultural.}

Com fulcro nas atribuições constitucionais de que "o Estado garantirá a todos o pleno exercício dos direitos culturais e acesso às fontes da cultura nacional, e apoiará e incentivará a valorização e difusão das manifestações culturais" (artigo 215, caput, $\mathrm{CF} / 88$ ) e de que "a lei estabelecerá incentivos para a produção e conhecimento de bens e valores culturais" (artigo 216, § 3으, CF/88), o legislador ordinário criou instrumentos que fomentam a produção cultural no país, através do incentivo fiscal concedido pelo Estado a pessoas físicas ou jurídicas, doadoras ou patrocinadoras de um projeto cultural previamente aprovado pela Comissão Nacional de Incentivo à Cultura - CNIC, ou pela ação direta do Estado.

Ao conceder incentivos fiscais à produção cultural, o Estado brasileiro reconhece a necessidade de intervenção em um setor que ainda necessita apoio econômico para consolidar-se. Nas palavras do ilustre professor Ruy Barbosa Nogueira:

"Por meio de medidas fiscais, que excluem total ou parcialmente o crédito tributário, o Governo Central procura provocar a expansão econômica de uma determinada região

${ }^{110}$ CALABRE, Lia. Op. Cit. P. 117. 
ou determinados setores de atividade. (...) estas medidas por si sós, não são suficientes para provocar o resultado desejado. Somente quando são acompanhadas de outras medidas, criando condições econômicas e sociais favoráveis, é que poderão atingir seu objetivo. (...) O fato é que as exonerações tributárias de cunho extra-fiscal, por meio de incentivos - sejam elas chamadas isenções, reduções, favores, estímulos ou devolução do imposto pago - são expedientes que, acompanhados de outras medidas, só se completam quando adotados pelo poder nacional ou estejam dentro do contexto deste." ${ }^{111}$

Não basta, portanto, que somente o Estado cumpra seu papel como incentivador através da renúncia de sua receita. Caberá aos beneficiados do incentivo a realização de contrapartidas em prol da democratização cultural. Contrapartidas estas alcançadas através de, por exemplo, ingressos gratuitos ou com preços populares, da conscientização quanto à utilização do dinheiro público e do apoio a grupos de culturas populares ou grupos amadores. Daí, conclui-se que o incentivo à cultura não deve ser tratado como uma questão meramente de marketing pelo ponto de vista das empresas patrocinadoras, uma vez que em sua essência envolve aspectos de igualdade, justiça e direitos humanos. ${ }^{112}$

Serão abordados neste subitem os mecanismos para fomento e custeio de projetos, ações culturais e programas instituídos pelo PRONAC ${ }^{113}$ (o Fundo Nacional da Cultura - FNC, Fundos de Investimento Cultural e Artístico - FICARTs e o Mecenato),

\footnotetext{
${ }^{111}$ NOGUEIRA, Ruy Barbosa. Curso de direito tributário. 11ạ Ed. São Paulo: Ed. Saraiva, 1993. P. 186-187

${ }^{112}$ Cf. TORRES, Ricardo Lobo. Curso de Direito Financeiro e Tributário. 17a Ed. Rio de Janeiro: Ed. Renovar, 2010. P. 316

${ }^{113} \mathrm{O}$ art. 20 do Decreto 5.761/2006 define as finalidades dos programas, projetos e ações culturais para que possam ser apoiados durante a execução do PRONAC: valorizar a cultura nacional, considerando suas várias matrizes e formas de expressão; estimular a expressão cultural dos diferentes grupos e comunidades que compõem a sociedade brasileira; viabilizar a expressão cultural de todas as regiões do País e sua difusão em escala nacional; promover a preservação e o uso sustentável do patrimônio cultural brasileiro em sua dimensão material e imaterial; incentivar a ampliação do acesso da população à fruição e à produção dos bens culturais; fomentar atividades culturais afirmativas que busquem erradicar todas as formas de discriminação e preconceito; desenvolver atividades que fortaleçam e articulem as cadeias produtivas e os arranjos produtivos locais que formam a economia da cultura; apoiar as atividades culturais de caráter inovador ou experimental; impulsionar a preparação e o aperfeiçoamento de recursos humanos para a produção e a difusão cultural; promover a difusão e a valorização das expressões culturais brasileiras no exterior, assim como o intercâmbio cultural com outros países; estimular ações com vistas a valorizar artistas, mestres de culturas tradicionais, técnicos e estudiosos da cultura brasileira; contribuir para a implementação do Plano Nacional de Cultura e das políticas de cultura do Governo Federal; e apoiar atividades com outras finalidades compatíveis com os
} 
assim como os mecanismos criados pela Lei do Audiovisual. Sublinha-se que o Código Tributário Nacional estipula em seu art. 111, inciso I, que toda a legislação tributária que disponha sobre isenção fiscal, que, por seu turno, é uma espécie de incentivo fiscal, deverá ser interpretada literalmente.

\subsubsection{1 - Fundo Nacional da Cultura - FNC.}

Com raízes no supracitado Fundo de Promoção Cultural - FPC, previsto na lei Sarney e extinto em 1990, o Fundo Nacional da Cultura - FNC nasce como um mecanismo criado a partir da necessidade de maior protagonismo estatal perante a efetivação do direito fundamental à cultura. Administrado pelo Ministério da Cultura e gerido pelo titular da pasta, o FNC é um fundo de natureza contábil, sem natureza jurídica própria, com prazo indeterminado de duração, que funciona sob as formas de apoio a fundo perdido ou empréstimos reembolsáveis. Os benefícios são concedidos pelo MinC através de "programas setoriais realizados por edital ou por uma de suas secretarias, ou apoiando propostas que, por sua singularidade, não se encaixam em linhas específicas de ação." 114

A lei estipula diversas fontes de recursos para a constituição do FNC: recursos do tesouro nacional; doações nos termos da legislação vigente; legados; subvenções e auxílios de entidades de qualquer natureza, inclusive de organismos internacionais; saldos não utilizados na execução de projetos incentivados por mecenato; devolução de recursos de projetos incentivados pelo próprio FNC ou por mecenato, e não iniciados ou interrompidos, com ou sem justa causa; um por cento da arrecadação dos Fundos de Investimentos Regionais, obedecida na aplicação a respectiva origem geográfica regional; três por cento da arrecadação bruta dos concursos de prognósticos e loterias federais e similares cuja realização estiver sujeita a autorização federal,

princípios constitucionais e os objetivos preconizados pela Lei no 8.313, de 1991, assim consideradas pelo Ministro de Estado da Cultura.

${ }^{114}$ MINISTÉRIO DA CULTURA. Apresentação de Projetos Culturais. Disponível em <http://www.cultura.gov.br>. Acesso em 08 set. 2011. 
deduzindo-se este valor do montante destinado aos prêmios; reembolso das operações de empréstimo realizadas através do fundo, a título de financiamento reembolsável, observados critérios de remuneração que, no mínimo, lhes preserve o valor real; resultado das aplicações em títulos públicos federais; conversão da dívida externa com entidades e órgãos estrangeiros unicamente mediante doações, no limite a ser fixado pelo Ministro da Economia, Fazenda e Planejamento, observadas as normas e procedimentos do Banco Central do Brasil; saldos de exercícios anteriores e recursos de outras fontes. ${ }^{115}$ Tais recursos só poderão ser aplicados após a aprovação do projeto pela Comissão do Fundo Nacional de Cultura, formada pelo Secretário-Executivo do Ministério da Cultura, pelos titulares das Secretarias do Ministério da Cultura, pelos Presidentes das entidades vinculadas ao Ministério da Cultura e por um representante do Gabinete do Ministro da Cultura, de modo a subsidiar sua aprovação pelo Ministro da Cultura. ${ }^{116}$

Observado o plano anual do PRONAC, os recursos poderão ser utilizados nas seguintes formas: recursos não-reembolsáveis para utilização em programas, projetos e ações culturais de pessoas jurídicas públicas ou privadas sem fins lucrativos; financiamentos reembolsáveis para programas, projetos e ações culturais de pessoas físicas ou pessoas jurídicas privadas, com fins lucrativos, por meio de agentes financeiros credenciados pelo Ministério da Cultura; concessão de prêmios; custeio de passagens e ajuda de custo para intercâmbio cultural, no Brasil ou no Exterior; transferência a Estados, Municípios e Distrito Federal para desenvolvimento de programas, projetos e ações culturais, mediante instrumento jurídico que defina direitos e deveres mútuos e outras situações definidas pelo Ministério da Cultura. ${ }^{117}$

Os objetivos do FNC foram definidos pela Lei Rouanet: captar e destinar recursos para projetos culturais compatíveis com as finalidades do PRONAC; estimular a distribuição regional equitativa dos recursos a serem aplicados na execução de projetos culturais e artísticos; favorecer a visão interestadual, estimulando projetos

\footnotetext{
${ }^{115}$ Artigo 5o da Lei no 8.313/91.

${ }^{116}$ Artigos 14 e 15 do Decreto no 5.761/2006.

${ }^{117}$ Artigo 10 do Decreto n 10 5.761/2006.
} 
que explorem propostas culturais conjuntas, de enfoque regional; apoiar projetos dotados de conteúdo cultural que enfatizem o aperfeiçoamento profissional e artístico dos recursos humanos na área da cultura, a criatividade e a diversidade cultural brasileira; contribuir para a preservação e patrimônio cultural e histórico brasileiro; favorecer projetos que atendam às necessidades da produção cultural e aos interesses da coletividade, considerados os níveis qualitativos e quantitativos de atendimentos às demandas culturais existentes, o caráter multiplicador dos projetos através de seus aspectos sócio-culturais e a priorização de projetos em áreas artísticas e culturais com menos possibilidade de desenvolvimento com recursos próprios. ${ }^{118}$

Caberá ao FNC financiar até $80 \%$ do custo total de cada programa, projeto ou ação cultural aprovado pelo Ministério da Cultura. A contrapartida, isto é, os $20 \%$ restantes, deverá ser obrigatoriamente oferecida pelo proponente para a complementação do custo total do programa, projeto ou ação cultural e deverá ser efetivada mediante aporte de numerário, bens ou serviços, ou comprovação de que está habilitado à obtenção do respectivo financiamento por meio de outra fonte devidamente identificada, vedada como contrapartida a utilização do mecanismo de incentivos fiscais $^{119}$. Excetua-se a necessidade de contrapartida na hipótese dos recursos terem sido depositados no FNC com destinação especificada na origem, tais como: a transferência de recursos a programas, projetos e ações culturais identificados pelo doador ou patrocinador por ocasião do depósito ao Fundo Nacional da Cultura, desde que correspondam ao custo total do projeto, programa ou ação cultural; e programas, projetos e ações identificados pelo autor de emendas aditivas ao orçamento do Fundo Nacional da Cultura, ainda que o beneficiário seja órgão federal, desde que o valor da emenda corresponda ao custo total do projeto, programa ou ação cultural. $^{120}$

$\mathrm{Na}$ qualidade de receita pública, os recursos do FNC estão sujeitos a rigoroso controle pelo Ministério da Cultura. Desta forma, o proponente, quando do término da

\footnotetext{
${ }^{118}$ Artigo 4워 da Lei no 8.313/91.

${ }^{119}$ Artigo 12, caput e parágrafo único do Decreto no 5.761/2006.

${ }^{120}$ Artigo 13 do Decreto no 5.761/2006.
} 
execução dos programas, projetos ou ações culturais beneficiados, deverá apresentar prestação de contas perante o Ministério, que, por sua vez, deverá, no prazo de seis meses, fazer uma avaliação final acerca da aplicação correta dos recursos, podendo inabilitar seus responsáveis pelo prazo de até três anos ${ }^{121}$ na hipótese de irregularidades, não excluída a responsabilidade criminal de cada um.

A previsão constitucional da obrigação de prestar contas perante o Poder Público por aquele que utiliza de qualquer mecanismo instituído pelo PRONAC, cuja fiscalização também poderá ser realizada pelo Tribunal de Contas da União, tem respaldo no artigo 70, parágrafo único da Constituição de $1988 .{ }^{122}$

Sobre a importância concebida pelo Estado Brasileiro aos fundos para a cultura nos quais o FNC faz parte, Fabíola Bezerra Brasil expõe que:

"O reconhecimento da necessidade de existência dos fundos voltados à cultura é de fundamental importância para a execução de política pública para o setor, comprometida com os princípios constitucionais, haja vista serem, os mesmos, instrumentos hábeis a garantir às manifestações culturais de menor expressão econômica a oportunidade de financiamento público, uma vez que normalmente não interessam à iniciativa privada nem se enquadram na sistemática de outros mecanismos." 123

\subsubsection{2 - Fundos de Investimento Cultural e Artístico - FICARTs.}

Os Fundos de Investimento Cultural e Artístico - FICARTs são fundos constituídos sob a forma de condomínio, sem personalidade jurídica, caracterizando comunhão de recursos destinados à aplicação em projetos culturais e artísticos. ${ }^{124}$ Para os fins de aplicação de seus recursos, são considerados projetos culturais e artísticos aqueles que envolvam a produção comercial de instrumentos musicais, bem como de discos, fitas, vídeos, filmes e outras formas de reprodução fonovideográficas; produção

\footnotetext{
${ }^{121}$ Artigo 20, § 10 da Lei no 8313/91.

${ }^{122}$ Art. 70 da CF/88 dispõe que "prestará contas qualquer pessoa física ou jurídica, pública ou privada, que utilize, arrecade, guarde, gerencie ou administre dinheiros, bens e valores públicos ou pelos quais a União responda, ou que, em nome dela, assuma obrigações de natureza pecuniária."

${ }^{123}$ BRASIL, Fabíola Bezerra de Castro Alves. O Fundo Nacional da Cultura como instrumento público de financiamento cultural. In: Políticas Culturais em Revista. Vol. 3. N.⒉ Salvador: Ed. UFBA, 2010. P. 152. Disponível em <http://www.politicasculturaisemrevista.ufba.br>. Acesso em 28 set. 2011.

${ }^{124}$ Artigo 8o da Lei no 8.313/91.
} 
comercial de espetáculos teatrais de dança, música, canto, circo e demais atividades congêneres; a edição comercial de obras relativas às ciências, às letras e às artes, bem como de obras de referência a outras de cunho cultural; construção, restauração, reparação ou equipamento de salas e outros ambientes destinados a atividades com objetos culturais, de propriedades de entidades com fins lucrativos; outras atividades comerciais ou industriais, de interesse cultural, assim consideradas pelo Ministério da Cultura. ${ }^{125}$

As quotas dos FICARTs, emitidas sob a forma nominativa ou escritural, constituem valores mobiliários sujeitos ao regime da Lei $\mathrm{n}$ - 8.167/1991. ${ }^{126}$ Os rendimentos e ganhos de capital auferidos pelos FICARTs ficam isentos de imposto sobre operações de crédito, câmbio e seguro, assim como do imposto sobre renda e proventos de qualquer natureza ${ }^{127}$. Já os rendimentos e ganhos de capital distribuídos pelos FICARTs, sob qualquer forma, sujeitam-se à incidência do imposto sobre a renda na fonte à alíquota de $25 \%{ }^{128}$ Exclui-se desta incidência na fonte os rendimentos distribuídos a beneficiário pessoa jurídica tributada com base no lucro real, os quais deverão ser computados na declaração anual de rendimentos. ${ }^{129}$

Compete à Comissão de Valores Mobiliários - CVM disciplinar a constituição, o funcionamento e a administração dos FICARTs, prestando informações ao Ministério da Cultura sobre sua constituição e seus respectivos agentes financeiros. ${ }^{130} \mathrm{~A}$ aplicação dos recursos dos FICARTs será realizada por meio da contratação de pessoas jurídicas com sede no território brasileiro, tendo por finalidade exclusiva a execução de programas, projetos e ações culturais; participação em programas, projetos e ações culturais realizados por pessoas jurídicas de natureza cultural com sede no território

\footnotetext{
${ }^{125}$ Artigo 9o da Lei no 8.313/91.

126 Artigo 11 da Lei no 8.313/91.

${ }^{127}$ Artigo 14 da Lei $n$ o 8.313/91.

${ }^{128}$ Artigo 15 da Lei no 8.313/91.

${ }^{129}$ Artigo 15, parágrafo único da Lei no 8.313/91.

${ }^{130}$ Artigo 18 do Decreto no 5.761/2006.
} 
brasileiro; e aquisição de direitos patrimoniais para exploração comercial de obras literárias, audiovisuais, fonográficas e de artes cênicas, visuais, digitais e similares. ${ }^{131}$

Com o a advento do Decreto 5.761/2006, ficou estipulado que o Ministério da Cultura definirá, em articulação com a Comissão de Valores Mobiliários - CVM, regras e procedimentos para acompanhamento e fiscalização da execução dos programas, projetos e ações culturais beneficiados com os recursos do FICARTs. ${ }^{132}$ De acordo com Fábio de Sá Cesnik, o texto legal é

"inadequado, já que não cabe ao Governo a fiscalização de recursos eminentemente privados. A fiscalização, nesse caso, deveria se limitar ao interesse dos investidores no âmbito da Comissão de Valores Imobiliários. Caso o Ministério resolva colocar o novo texto em prática, ficará ainda mais difícil uma instituição financeira se interessar por abrir um FICART." 133

À vista do que foi exposto acima, os FICARTs até hoje nunca foram utilizados devido à falta de interesse por parte de empresas privadas e instituições financeiras.

\subsubsection{3 - Mecenato.}

Conforme estudado no item anterior, a prática do mecenato, oriunda do Império Romano e fundamentada sobre uma ideia saudosista de promover a reaproximação entre os "mecenas" e os artistas com o intuito de apoiar o desenvolvimento da realização de obras através de seu financiamento ${ }^{134}$, se faz presente hoje de forma adaptada. Trata-se de um mecanismo em que o Poder Público, com o objetivo de incentivar atividades culturais renuncia parte do que receberia de Imposto de Renda devido por pessoas físicas ou jurídicas que patrocinarem ou doarem quantias a projetos culturais apresentados por pessoas físicas ou jurídicas de natureza cultural (denominados proponentes) e aprovados pela Comissão Nacional de Incentivo à Cultura - CNIC. Seus membros não poderão apreciar os projetos de maneira subjetiva

\footnotetext{
${ }^{131}$ Artigo 20 do Decreto no 5.761/2006.

${ }^{132}$ Artigo 21 do Decreto no 5.761/2006.

${ }^{133}$ CESNIK, Fábio de Sá. Guia do Incentivo à Cultura. 2a Edição. São Paulo, Ed. Manole, 2007. P. 31.

${ }^{134}$ Cf. CUNHA FILHO, Francisco Humberto. Op. Cit. P. 105.
} 
quanto ao seu valor artístico ou cultural. ${ }^{135}$ Ressalta-se que as contribuições provenientes do Fundo Nacional de Cultura - FNC não poderão ser excluídas do projeto contemplado pelo mecanismo do mecenato.

Os valores que poderão ser deduzidos do Imposto de Renda via renúncia fiscal por pessoas físicas ou jurídicas, a título de doação ou patrocínio, variam de acordo com a natureza do projeto cultural. A Lei Rouanet permite que, através de doações ou patrocínios, os contribuintes deduzam do Imposto de Renda devido 100\% (cem por cento) das quantias despendidas em projetos culturais, não permitida sua utilização como despesa operacional pela empresa patrocinadora, desde que tenham como objeto os seguintes segmentos artísticos: artes cênicas; livros de valor artístico, literário ou humanístico; música erudita ou instrumental; exposições de artes visuais; doações de acervos para bibliotecas públicas, museus, arquivos públicos e cinematecas, bem como o treinamento de pessoal e aquisição de equipamentos para a manutenção desses acervos; produção de obras cinematográficas e videofonográficas de curta e média metragem e preservação e difusão do acervo audiovisual; preservação do patrimônio cultural material e imaterial; construção e manutenção de salas de cinema e teatro, que poderão também ser utilizados como centros culturais comunitários em Municípios com menos de cem mil habitantes. ${ }^{136}$

Dentro de um escopo mais amplo, a Lei Rouanet reconhece outros segmentos que poderão ser contemplados por projetos apresentados por pessoas físicas ou pessoas jurídicas de natureza cultural que objetivem desenvolver as formas de expressão, os modos de criar e fazer, os processos de preservação e proteção do patrimônio cultural brasileiro, os estudos e métodos de interpretação da realidade cultural, propiciando meios que permitam o conhecimento dos bens e valores artísticos e culturais à população. São eles: teatro, dança, circo ópera, mímica e congêneres; produção cinematográfica, videográfica, fotográfica, discográfica e congêneres (somente produções independentes e/ou culturais-educativas de caráter não

\footnotetext{
${ }^{135}$ Artigo 22 da Lei no 8.313/91.

${ }^{136}$ Artigo 18 da Lei no 8.313/91.
} 
comercial, realizadas por empresas de rádio e televisão); literatura, inclusive obras de referência; música; artes plásticas, artes gráficas, gravuras, cartazes, filatelia e outros congêneres; folclore e artesanato; patrimônio cultural, inclusive histórico, arquitetônico, arqueológico, bibliotecas, museus, arquivos e demais acervos; humanidades e; rádio e televisão, educativas e culturais, de caráter não comercial $^{137}$. Nestes segmentos, as pessoas físicas poderão abater $80 \%$ (oitenta por cento) das doações e $60 \%$ (sessenta por cento) dos patrocínios, enquanto as pessoas jurídicas tributadas com base no lucro real poderão abater $40 \%$ (quarenta por cento) das doações e $30 \%$ (trinta por cento) dos patrocínios. ${ }^{138}$ A lei faculta à pessoa jurídica abater as doações e patrocínios como despesa operacional. ${ }^{139}$

Fábio de Sá Cesnik esclarece a diferença entre doação e patrocínio no âmbito da aplicação da Lei Rouanet:

"patrocínio é aplicação de recursos de um patrocinador buscando retorno de marketing e, portanto, com vista à valorização da marca da empresa incentivadora. Para fins tributários, também seu enquadramento para recolhimento ao fisco é diferenciado em relação à doação. (...) a doação, por seu turno, não reverte em marketing para o patrocinador, que não pode fazer publicidade paga do evento patrocinado, não tendo nada em que vede a menção à marca no produto incentivado. Também existem benefícios em termos do imposto investido." 140

Independentemente dos dois graus de abatimento, deverão ser respeitados os limites de seis por cento para pessoas físicas e quatro por cento para pessoas jurídicas do total do Imposto de Renda devido. ${ }^{141}$

Acrescenta-se que a Lei Rouanet equiparou à doação as distribuições gratuitas de ingressos para eventos de caráter artístico-cultural por pessoa jurídica a seus empregados e dependentes legais, assim como as despesas efetuadas por pessoas físicas ou jurídicas com o objetivo de conservar, preservar ou restaurar bens de sua propriedade ou sob sua posse legítima, desde que tombados pelo Governo Federal. ${ }^{142}$

\footnotetext{
${ }^{137}$ Artigo 25 da Lei no 8.313/91.

${ }^{138}$ Artigo 26 da Lei no 8.313/91.

${ }^{139}$ Artigo 26, § 10 da Lei no 8.313/91.

${ }^{140}$ CESNIK, Fábio de Sá. Op. Cit. P. 37.

${ }^{141}$ Artigo 26, parágrafo único e Artigo 30, §2ํㅡ, ambos do Decreto № 5.761/2006.

${ }^{142}$ Artigo 24 da Lei no 8.313/91.
} 
Ela também obriga que os planos de distribuição de produtos decorrentes de programas, projetos e ações culturais financiados pelo PRONAC deverão obedecer a dois critérios: até dez por cento dos produtos poderão ser utilizados com a finalidade de distribuição gratuita e promocional pelo patrocinador, assim como outros dez por cento dos produtos deverão ser distribuídos de forma gratuita pelo beneficiário, a critério do Ministério da Cultura. ${ }^{143}$

Sublinha-se que a Lei em comento estipulou que as ações, programas e projetos culturais somente serão beneficiados pelo PRONAC se suas exibições, utilizações e circulações de bens deles resultantes sejam abertas, sem distinção, a qualquer pessoa, se gratuitas, e ao público pagante, se cobrado ingresso ${ }^{144}$ cujo valor, ao ver do autor da presente monografia, deverá ser justo, a despeito das práticas ocorridas nos últimos anos. Tais produtos e serviços deverão ser exibidos, utilizados e circulados publicamente, sendo vedadas destinações ou restrições a circuitos privados ou coleções particulares que estabeleçam limites de acesso. ${ }^{145}$

O incentivo fiscal permitiu a criação e firmação do marketing cultural, expressão genuinamente brasileira. Finaliza-se o presente subitem com a seguinte indagação: até que ponto o direito fundamental à cultura deverá estar à mercê dos interesses de empresas privadas que querem apenas vincular sua marca a um projeto que atraia um determinado tipo de público, sem nenhum compromisso com o desenvolvimento cultural, de fato, em detrimento da renúncia fiscal do Estado?

\subsubsection{4 - Lei do Audiovisual.}

A Lei $n$ ㅇ 8.685, de 20 de julho de 1993, popularmente conhecida como Lei do Audiovisual, criou quatro diferentes mecanismos para o fomento da atividade cinematográfica e audiovisual brasileira, indústria que sofreu um verdadeiro baque quando da extinção da Embrafilme, em 1990. Seus sustentáculos são três mecanismos

\footnotetext{
${ }^{143}$ Artigo 44 do Decreto no 5.761/2006.

${ }^{144}$ Artigo 2으, § 1으 da Lei no 8.313/91.

${ }^{145}$ Artigo 2으, § 2ㅇda Lei no 8.313/91.
} 
de investimento e um de patrocínio que envolvem, novamente, a prática de renúncia fiscal.

O primeiro mecanismo previsto na lei permite aos contribuintes, até o exercício fiscal de 2016, deduzirem do imposto de renda devido as quantias referentes a investimentos feitos na produção de obras audiovisuais cinematográficas brasileiras de produção independente, mediante a aquisição de quotas representativas de direitos de comercialização sobre as referidas obras, desde que esses investimentos sejam realizados no mercado de capitais, em ativos previstos em lei e autorizados pela Comissão de Valores Imobiliários - CVM, e os projetos de produção tenham sido previamente aprovados pela Agência Nacional do Cinema - $\mathrm{ANCINE}^{146}$, agência reguladora criada pela Medida Provisória no 2.228-1, de 6 de setembro de 2001. Haverá, assim, duas vantagens: será deduzido do imposto de renda a pagar no exercício fiscal o valor investido na obra, como também será garantida a participação dos investidores nos resultados positivos que a obra venha a dar (cotas de Direito de Comercialização). ${ }^{147}$ Cabe frisar que os limites para dedução do Imposto de Renda devido são de três por cento para pessoa física e um por cento para pessoa jurídica.

O segundo mecanismo apresenta semelhanças com o Mecenato previsto na Lei Rouanet uma vez que autoriza, até o ano de 2016, aos contribuintes deduzirem do imposto de renda devido as quantias referentes ao patrocínio à produção de obras cinematográficas brasileiras de produção independente, aprovadas previamente pela ANCINE. Imposto de renda este apurado na declaração de ajuste anual pelas pessoas físicas e em cada período de apuração (trimestral ou anual) pelas pessoas jurídicas tributadas com base no lucro real. ${ }^{148} \mathrm{O}$ legislador também autorizou a ANCINE instituir programas especiais de fomento ao desenvolvimento da atividade audiovisual brasileira para a fruição dos incentivos fiscais relacionados a este mecanismo, v.g., o Programa Apoio à Participação de Filmes Brasileiros em Festivais Internacionais.

\footnotetext{
${ }^{146}$ Artigo 1ㅇda Lei no 8.685/93.

${ }^{147}$ Cf. MARTINS, Vinicius. Fundamentos da atividade cinematográfica e audiovisual: teoria e prática. Rio de Janeiro: Ed. Elsevier, 2009. P. 189.

${ }^{148}$ Artigo 1ㅇ-A da Lei no 8.6.85/1993.
} 
A soma dos valores aportados através destes dois primeiros mecanismos não poderá ultrapassar a ordem de $\mathrm{R} \$ 4.000 .000,00$ (quatro milhões de reais). ${ }^{149}$

O terceiro mecanismo permite que os contribuintes do Imposto de Renda incidentes nos termos do artigo 72 da Lei $n$ o $9.430^{150}$, de 27 de dezembro de 1996, poderão beneficiar-se de abatimento de 70\% (setenta por cento) do imposto devido, desde que invistam no desenvolvimento de projetos de produção de obras cinematográficas brasileiras de longa metragem de produção independente, e na coprodução de telefilmes e minisséries brasileiros de produção independente e de obras cinematográficas brasileiras de produção independente. ${ }^{151}$ A pessoa jurídica responsável pela remessa das importâncias pagas, creditadas, empregadas ou remetidas aos contribuintes de que trata este mecanismo terá preferência na utilização dos recursos decorrentes deste benefício fiscal. ${ }^{152}$ Para tal, o contribuinte poderá transferir expressamente ao responsável pelo pagamento ou remessa o benefício em questão através de dispositivo contratual ou documento especialmente constituído para esses fins. ${ }^{153}$

Por fim, o quarto mecanismo possibilita aos contribuintes do Imposto de Renda incidente nos termos do art. 72 da Lei $\mathrm{n}^{\circ}$ 9.430, de 27 de dezembro de 1996, (beneficiários do crédito, emprego, remessa, entrega ou pagamento pela aquisição ou remuneração, a qualquer título, de direitos, relativos à transmissão, por meio de radiodifusão de sons e imagens e serviço de comunicação eletrônica de massa por assinatura, de quaisquer obras audiovisuais ou eventos, mesmo os de competições desportivas das quais faça parte representação brasileira) se beneficiar de abatimento de $70 \%$ (setenta por cento) do imposto devido, desde que invistam no desenvolvimento de projetos de produção de obras cinematográficas brasileiras de

\footnotetext{
${ }^{149}$ Artigo 4으, §2으, inciso II da Lei no 8.6.85/1993.

${ }^{150}$ "As importâncias pagas, creditadas, empregadas, remetidas ou entregues aos produtores, distribuidores ou intermediários no exterior, como rendimentos decorrentes da exploração de obras audiovisuais estrangeiras ou em todo o território nacional, ou por sua aquisição ou importação a preço físico, ficam sujeitas ao imposto de $25 \%$ na fonte."

${ }^{151}$ Artigo 3음 da Lei no 8.685/1993.

${ }^{152}$ Artigo 3으, §1으 da Lei no 8.6.85/1993.

${ }^{153}$ Artigo 3ㅇ, § 20 da Lei № 8.6.85/1993.
} 
longa-metragem de produção independente e na coprodução de obras cinematográficas e videofonográficas brasileiras de produção independente de curta, média e longas-metragens, documentários, telefilmes e minisséries ${ }^{154}$. A pessoa jurídica responsável pela remessa das importâncias pagas, creditadas, empregadas, entregues ou remetidas aos contribuintes terá preferência na utilização dos recursos decorrentes desta modalidade de benefício fiscal. Para o exercício deste direito de preferência o contribuinte poderá transferir expressamente ao responsável pelo crédito, emprego, remessa, entrega ou pagamento o benefício de que trata o caput deste artigo em dispositivo do contrato ou por documento especialmente constituído para esses fins. ${ }^{155}$

A soma destes dois últimos mecanismos não poderá exceder o valor de $\mathrm{R} \$ 3.000 .000,00$ (três milhões de reais). ${ }^{156}$

Por fim, deve ser colocado que: i) proponente deverá arcar a contrapartida através de recursos próprios ou de terceiros correspondentes a $5 \%$ (cinco por cento) do orçamento total aprovado pela ANCINE, comprovados ao final de sua realização ${ }^{157}$; ii) os mecanismos consignados na Lei do Audiovisual poderão ser utilizados concomitantemente com os consignados na Lei Rouanet, desde que sejam respeitados os limites de valores expostos acima. ${ }^{158}$

\subsection{2 - Instrumentos para a Tutela do Patrimônio Cultural Brasileiro.}

Conforme examinado no capítulo anterior, a Constituição Federal de 1988 apresentou avanço ao adotar a moderna e abrangente expressão "patrimônio cultural brasileiro", consagrada em seu artigo 216, caput, em detrimento à limitada expressão "patrimônio histórico e artístico nacional", que ainda é mantida na legislação infraconstitucional. A expressão "patrimônio cultural brasileiro" engloba o "conjunto de

\footnotetext{
${ }^{154}$ Artigo 3--A da Lei no 8.6.85/1993.

${ }^{155}$ Artigo 3ㅇ-A, §§ 1으 e 2ㅇda Lei no 8.6.85/1993.

${ }^{156}$ Artigo 4으, §2으, inciso II da Lei $\mathrm{n}$ o 8.6.85/1993.

${ }^{157}$ Artigo 4으, § 2ㅇda Lei no 8.685/1993.

${ }^{158}$ Artigo 1으, inciso I do Decreto no 4.456/2002.
} 
bens materiais e imateriais que garantem ou revelam uma cultura" ${ }^{159}$ não só da União, mas também dos Estados e Municípios. Caso fosse utilizado adjetivo "nacional", daria a entender que a proteção se estenderia somente ao patrimônio cultural no âmbito federal.

No que tange à tutela do patrimônio cultural brasileiro, a Constituição, além de recepcionar os instrumentos de tombamento, vigilância e desapropriação previstos no Decreto-Lei no 25/1937 e a Ação Civil Pública, regida pela Lei no 7.347/1985, que, por seus turnos, deverão ser interpretados sob a atual ótica constitucional, prevê mais dois instrumentos que poderão ser utilizados de acordo com a finalidade de cada um: o inventário e o registro. Foi possibilitada, ainda, a criação pelo Poder Público de outras formas de acautelamento e preservação. Caberá agora analisar as principais.

\subsubsection{1 - Tombamento.}

Integrante da política pública cultural consubstanciada no Plano Nacional de Cultura, o instituto administrativo do Tombamento é regido pelo Decreto-Lei no 25/1937, popularmente conhecido como a Lei de Tombamento. Apesar de seus quase setenta e cinco anos de idade, o Decreto ainda é o principal instrumento de tutela do patrimônio cultural brasileiro que se encontra em vigor. A moderna doutrina, aqui representada por Inês Virgínia Prado Soares, define o tombamento como

"um procedimento administrativo que tem suas normas gerais estabelecidas em lei para que, no exercício da função administrativa, seja reconhecido o valor histórico, artístico, paisagístico, arqueológico, bibliográfico, cultural ou científico de bens públicos ou privados merecedores de tutela especial." ${ }^{160}$

A seguir, a autora expõe as consequências declaratórias e obrigacionais decorrentes do tombamento para o Estado e a sociedade:

"Com o tombamento ocorre a declaração oficial de que o bem integra o patrimônio cultural brasileiro e com isso o Estado não somente torna de conhecimento público o valor cultural presente naquele bem, como também resguarda permanentemente a

\footnotetext{
${ }^{159}$ SOUZA FILHO, Carlos Frederico Marés de. Bens Culturais e sua Proteção Jurídica. 3ạ Edição. Curitiba: Ed. Juruá, 2009. P. 47.

${ }^{160}$ SOARES, Inês Virgínia Prado. Op. Cit. P.293
} 
integridade dos elementos constitutivos do bem material, os quais devem ser cuidados e preservados, pelos proprietários e pelo Estado, para que possam ser fruídos pelas gerações presentes e futuras." ${ }^{161}$

O decreto em comento regula o processo administrativo do tombamento e seus efeitos, assim como estipula penalidades e define que o Instituto do Patrimônio Histórico e Artístico Nacional - IPHAN será o órgão competente para proteção do patrimônio cultural brasileiro. Entretanto, sua definição de patrimônio é muito limitada ${ }^{162}$ e condiciona os bens a serem considerados parte integrante do "patrimônio histórico e artístico nacional" à necessidade de inscrição em algum dos quatro Livros do Tombo de responsabilidade do IPHAN: o Livro do Tombo Arqueológico, Etnográfico e Paisagístico; o Livro do Tombo Histórico; o Livro do Tombo das Belas Artes; o Livro do Tombo das Artes Aplicadas. A promulgação da Constituição Federal de 1988 possibilitou-lhe uma nova exegese, "limpando a pátina que o tempo havia depositado no diploma legal que "organiza a proteção do patrimônio histórico e artístico nacional", revelando sua beleza original. "163 Neste novo escopo constitucional desvincula-se a necessidade do ato de tombamento como condição para que determinado bem seja considerado parte integrante do patrimônio cultural brasileiro ${ }^{164}$, como também ficam estipulados novos critérios para sua proteção: portar referência à identidade, à ação e à memória dos diferentes grupos formadores da sociedade brasileira. Neste diapasão, apesar de recair apenas em bens materiais, o tombamento tutela também bens imateriais através de um suporte, conforme atestado por Sonia Rabello de Castro: "o

\footnotetext{
161 Ibid. P.294

${ }^{162}$ Artigo 10 do Decreto-Lei no 25/1937: “Constitui o patrimônio histórico e artístico nacional o conjunto dos bens móveis e imóveis existentes no país e cuja conservação seja de interesse público, quer por sua vinculação a fatos memoráveis da história do Brasil, quer por seu excepcional valor arqueológico ou etnográfico, bibliográfico ou artístico."

163 SOUZA FILHO, Carlos Frederico Marés de. Op. Cit. P. 66.

${ }^{164}$ Após a promulgação da Constituição de 1988, o tombamento passa a ser um ato declaratório em relação aos bens culturais. Já aos proprietários, o tombamento continua sendo um ato constitutivo, uma vez que o direito à propriedade é um direito fundamental (artigo 5ㅇ, inciso XII) e quaisquer limitações à ele devem estar previstas em lei. (Cf. SOARES, Inês Virgínia Prado. Op. Cit. P.295).
} 
bem jurídico, objeto de proteção, está materializado na coisa, mas não é a coisa em si: é o significado simbólico, traduzido pelo valor cultural que representa." 165

Há três diferentes modalidades de tombamento previstos no Decreto-Lei № 25/1937:

a) Tombamento de ofício: o tombamento dos bens pertencentes à União, aos Estados e aos Municípios será realizado por ofício, por ordem do IPHAN, mas deverá ser notificado à entidade a quem pertencer, ou sob cuja guarda estiver a coisa tombada, a fim de produzir os necessários efeitos. ${ }^{166}$ Neste caso, não há contraditório. Já os monumentos arqueológicos ou pré-históricos de qualquer natureza existentes no território nacional e todos os elementos que neles se encontram ficam imediatamente sob a guarda e proteção do Poder Público, dispensando-se assim, a necessidade do tombamento ${ }^{167}$, necessitando apenas seus registros.

b) Tombamento voluntário: ocorre quando o proprietário de bem móvel ou imóvel que seja revestido dos requisitos necessários para constituir parte integrante do patrimônio histórico e artístico nacional requer o tombamento ao órgão responsável, devendo o pedido ser analisado pelo Conselho Consultivo do IPHAN. Ou sempre que o proprietário, quando notificado pelo Poder Público da iniciativa de tombar o bem, anuir, por escrito, para a inscrição do bem no Livro do Tombo correspondente. ${ }^{168}$

c) Tombamento compulsório (provisório ou definitivo): No momento em que a administração pública notifica o proprietário de determinado bem acerca da iniciativa de tombá-lo, ocorre o tombamento provisório, um ato discricionário que visa à preservação do bem particular no decorrer do processo administrativo, como se estivesse tombado. ${ }^{169}$ Caso o proprietário no prazo de 15 (quinze) dias recuse 0 tombamento, o processo administrativo é remetido para o Conselho Consultivo do

\footnotetext{
${ }^{165}$ CASTRO, Sonia Rabello de. O Estado na Preservação de Bens Culturais. Rio de Janeiro: Ed. Renovar, 1991. P. 33.

${ }^{166}$ Artigo 5o do Decreto-Lei no 25/1937.

${ }^{167}$ Artigo 1ㅇd da Lei no 3.924/1961.

${ }^{168}$ Artigo 70 do Decreto-Lei no. 25/1937.

${ }^{169}$ Artigo 10 do Decreto-Lei no 25/1937.
} 
IPHAN para sua apreciação. ${ }^{170}$ Após sua manifestação, da qual não cabe recurso, caberá ao Ministro da Cultura homologar o tombamento que a partir daí será definitivo. ${ }^{171}$ No entanto, caso o proprietário reconheça aspectos de ilegalidade no ato administrativo discricionário que tombou seu bem de forma provisória ou definitiva, poderá, com fulcro no princípio constitucional da inafastabilidade da Jurisdição (artigo 5ํ, inciso XXXV da CF/88), acionar o Poder Judiciário que, por sua vez, não poderá analisar seu mérito sob hipótese de violação ao princípio da separação dos poderes (artigo 2o da CF/88).

Depois de tombados, os bens não poderão ser, em nenhuma hipótese, destruídos, demolidos ou mutilados, nem, sem prévia autorização especial do IPHAN, ser reparados, pintados ou restaurados. ${ }^{172}$ Caso o proprietário do bem tombado não disponha de recursos para proceder às obras de conservação e reparação, deverá levar ao conhecimento do IPHAN a necessidade das mencionadas obras. ${ }^{173}$ De acordo com Carlos Frederico Marés de Souza Filho, o tombamento

"não significa, evidentemente, que ele será preservado, mas a cidadania e o Poder Público passam a ter meios de assegurar que ele não seja alterado, conspurcado, deteriorado, destruído, e todas as alterações ou modificações que venha a ter dependem de autorização do órgão que o tombou." ${ }^{174}$

Dentre outros efeitos do tombamento previstos no Decreto-Lei no 25/1937, são eles: i) o direito de preferência da União, Estados e Municípios, nesta ordem, quando da alienação onerosa do bem tombado pelo proprietário. A notificação por parte do proprietário do bem sobre o direito de preferência do Poder Público deve ocorrer no prazo de trinta dias, sob pena de perdê-lo; ii) a inalienabilidade reforçada dos bens tombados, uma vez que só podem ser alienados mediante autorização legal. Caso os bens pertençam à União, aos Estados ou Municípios, só poderão ser transferidos entre si; iii) a anotação do bem no registro de imóveis competente; iv) a proibição de

\footnotetext{
${ }^{170}$ Artigos 8ㅇ e 9o do Decreto-Lei no 25/1937.

${ }^{171}$ Lei no 6.292/1975.

${ }^{172}$ Artigo 17 do Decreto-Lei no 25/1937.

${ }^{173}$ Artigo 19 do Decreto-Lei no. 25/1937.

${ }^{174}$ SOUZA FILHO, Carlos Frederico Marés de. Op. Cit. P. 101.
} 
construção que impeça ou reduza a visibilidade na vizinhança de bem tombado, sem a prévia autorização do IPHAN, nem nela colocar anúncios ou cartazes, sob pena de sua destruição ou retirada e; v) a impossibilidade do bem tombado não sair do país, se não por curto prazo, sem transferência do domínio e para fim de intercâmbio cultural, a juízo do Conselho Consultivo do IPHAN.

Não deve ser olvidado que a Constituição Federal de 1998 assegurou, em seu artigo 216, §5으 o tombamento de todos os documentos e os sítios detentores de reminiscências histórias dos antigos quilombos.

\subsubsection{2 - Inventário.}

Mencionado no artigo 216, § 1 o da Constituição Federal de 1988 como um instrumento de proteção do patrimônio cultural brasileiro, abrangendo, assim, bens materiais e imateriais, móveis e imóveis, públicos e privados, nacionais e estrangeiros desde que fixados no Brasil, o Inventário torna possível a "reunião de dados acerca da dimensão e da importância do bem cultural para a região (e para a comunidade que nela vive) e viabiliza o planejamento de ações do Poder Público na tutela e manejo dos bens inventariados". 175

Trata-se de um instrumento de caráter preventivo, sistematizador e informativo cuja "elaboração e implementação devem proporcionar o acesso, fruição, conhecimento e registro dos bens que integram o patrimônio cultural da comunidade ou região." 176 Embora não haja lei específica que o regularize, o Inventário é amplamente utilizado como instrumento de trabalho para estudos que serão transformados em subsídios para ações que promovam e protejam o patrimônio cultural brasileiro. No silêncio do legislador ordinário no que se refere ao seu modo de proceder, caberá à Administração Pública, em seu âmbito, a realização do Inventário.

\footnotetext{
175 SOARES, Inês Virgínia Prado. Op. Cit. P.287.

176 Ibid. P. 287.
} 
O Instituto do Patrimônio Histórico e Artístico - IPHAN utiliza o Inventário como instrumento de trabalho de maneira recorrente, principalmente para ações que visam à tutela de bens imateriais e seus respectivos Registros como integrantes do patrimônio cultural brasileiro. Destaca-se o Inventário Nacional de Referências Culturais - INRC, metodologia de pesquisa criada pela autarquia federal com escopo na política de valorização do patrimônio imaterial cujo marco inicial foi o Decreto $\mathrm{n}$ 3.551 de 4 de agosto de 2.000. Nos termos empregados pelo IPHAN, o objetivo do INRC é "produzir conhecimento sobre domínios da vida social aos quais são atribuídos sentidos e valores e que, portanto, constituem marcos e referências de identidade para determinado grupo social." ${ }^{177}$ De acordo com seu site, até 19 de janeiro de 2010 foram realizados 58 inventários pelos quais incluem o INRC do Jongo - RJ, o INRC da Feira de Caruaru - PE, o INRC do Ofício das Baianas de Acarajé - BA, o INRC das Comunidades Quilombolas do Norte do Espírito Santo - ES entre outros.

\subsubsection{3 - Vigilância.}

O instrumento de gestão do patrimônio cultural denominado Vigilância foi citado pelo legislador constituinte no artigo 216 , $§ 1$ o e não regulado pelo legislador ordinário, assim como o Inventário. Segundo Inês Virgínia Prado Soares, não é necessária a promulgação de uma lei que o regule, haja vista que a é "puro exercício das atribuições que são inerentes aos órgãos diretamente responsáveis pela proteção dos bens culturais e pelo zelo do interesse público." 178

De acordo com a mesma autora, extraem-se da Vigilância dois deveres para o Poder Público oriundos do seu Poder de Polícia: agir e não se omitir. No que se refere ao primeiro dever, à Administração Pública caberá, através de atos normativos e atos fiscalizadores, proteger o patrimônio cultural "condicionando os que estão de posse de um bem cultural ou que exercerão atividade potencialmente causadora de dano (...) a

\footnotetext{
177 Instituto do Patrimônio Histórico e Artístico Nacional - IPHAN. Inventário Nacional de Referências Culturais. Disponível em <http://www.iphan.gov.br>. Acesso em 07 out. 2011.

${ }^{178}$ SOARES, Inês Virgínia Prado. Op. Cit. P.290.
} 
um comportamento de cuidado." ${ }^{179} \mathrm{O}$ agir seria realizado por via de delegação de tarefas, produção de informações e coordenação entre os próprios entes públicos. No que se refere ao segundo dever, é exigido ao Poder Público que "invista em recursos humanos e financeiros para tutelar os bens culturais, além de ter o dever de estabelecer e aprimorar os mecanismos administrativos com a finalidade de atender num prazo razoável as demandas da sociedade em relação a esses bens." 180

Portanto, a função da vigilância, competência comum da União, Estados e Municípios (artigo 23, incisos III e IV c/c artigo 30, inciso IX, ambos da CF/88), é afastar eventuais danos ao patrimônio cultural brasileiro, e se ocorridos, restaurá-los. Desta forma, o Poder Público deverá estar sempre atento a casos de destruição ou abandono de bens tombados. A propósito, o Decreto-Lei no 25/1937 já mencionava o instrumento em comento em seu artigo 20, quando sujeitou os bens tombados à vigilância permanente do IPHAN, que poderá inspecioná-los sempre que for julgado conveniente, não podendo seus proprietários ou responsáveis criar obstáculos quanto à sua realização.

\subsubsection{4-Registro.}

Embora já utilizado por entes federativos desde a década de 1970, o Instrumento do Registro, a partir da promulgação do Decreto no 3.551/2000, que institui o Registro de Bens Culturais de Natureza Imaterial e criou o Programa Nacional do Patrimônio Imaterial, passou a ser compreendido, tanto pelo Poder Público quanto pela sociedade, como o mecanismo específico para tutelar o patrimônio imaterial, preservando, assim, sua memória.

O artigo 1 - do referido Decreto, inspirado no Decreto-Lei no 25/1937, criou quatro diferentes livros de registros: o Livro de Registro dos Saberes, "onde ficarão inscritos conhecimentos e modos de fazer enraizados no cotidiano das comunidades"; o

\footnotetext{
179 Ibid. P. 290.

${ }^{180}$ Ibid. P. 290.
} 
Livro de Registro das Celebrações, "onde serão inscritos rituais e festas que marcam a vivência coletiva do trabalho, da religiosidade, do entretenimento e de outras práticas da vida social"; o Livro de Registro das Formas de Expressão, "onde serão inscritas manifestações literárias, musicais, plásticas, cênicas e lúdicas"; e o Livro do Registro de Lugares, "onde serão inscritos mercados, feiras, santuários, praças e demais espaços onde se concentram e reproduzem práticas culturais coletivas." O Decreto permitiu a abertura de outros livros, caso determinados bens culturais de natureza imaterial que constituam o patrimônio cultural brasileiro não se enquadrem nestes quatro livros.

Poderão provocar a abertura do processo administrativo que registre determinado bem como patrimônio imaterial brasileiro o Ministro de Estado da Cultura; instituições vinculadas ao Ministério da Cultura; Secretarias de Estado, de Município e do Distrito Federal; e sociedades ou associações civis. Após a análise e aprovação pelo IPHAN, o bem será inscrito no livro correspondente e receberá o título de "Patrimônio Cultural do Brasil."

Diferentemente do tombamento, que possui caráter permanente e não revogável, o Registro de Bens Culturais Imateriais estipula que o IPHAN reavaliará os bens culturais imateriais registrados pelo menos a cada dez anos. Na visão de Carlos Frederico Marés de Souza Filho,

"Há aqui um exagerado preciosismo do Decreto, já que tanto a ideia de tombamento como a do registro de bens imateriais é captar e preservar uma manifestação cultural de determinada época que tenha relevância formadora ou identificadora da cultura nacional. Portanto, se determinada manifestação cultural teve em determinado momento histórico essa relevância, deve ser registrado na memória oficial do povo, feito por meio do tombamento ou do registro. Se a prática é posteriormente desvirtuada ou esquecida, não se pode considerar que tenha perdido importância cultural ou histórica. Assim, não se trata de revalidar um título, mas de reconhecer a sua prática atual ou não." 181

Outros mecanismos de registros de bens culturais imateriais também poderão ser criados pelos Estados, Municípios e Distrito Federal, seja nos moldes do Decreto no

\footnotetext{
${ }^{181}$ SOUZA FILHO, Carlos Frederico Marés de. Op. Cit. P. 81.
} 
3.551/2000 ou não, haja vista que a Constituição prevê a competência comum dos entes federativos para a proteção do patrimônio cultural brasileiro.

\subsubsection{5 - Ação Popular.}

A Ação Popular está prevista no artigo 5으, inciso LXXIII, da Constituição Federal de 1988, transcrito aqui, in verbis:

"qualquer cidadão é parte legítima para propor ação popular que vise anular ato lesivo ao patrimônio público ou de entidade de que o Estado participe, à moralidade administrativa, ao meio ambiente e ao patrimônio histórico e cultural, ficando o autor, salvo comprovada a má-fé, isento de custas judiciais e do ônus de sucumbência."

Trata-se de um instrumento de previsão constitucional regulado pela Lei $\mathrm{n}$ o 4.717/1965 que busca, sobretudo, defender o interesse público e a ética administrativa. Ele transforma o cidadão em um fiscal do bem comum, que, por sua vez, se torna parte legítima para sua propositura ${ }^{182}$. Mesmo com a promulgação da Constituição Federal de 1988 prevalece o entendimento de que o cidadão só poderá ser sujeito ativo legítimo na Ação Popular se for eleitor, devendo estar no pleno gozo de seus direitos políticos. Quanto aos sujeitos passivos da Ação Popular, podem ser: i) as pessoas cujo patrimônio se pretende proteger (entes federativos, autarquias, empresas públicas, sociedades de economia mista e quaisquer outras pessoas jurídicas subvencionadas pelos cofres públicos); ii) aqueles que causaram ou que ameaçam, através de ato ou omissão, lesão aos bens tutelados pelo instrumento processual em comento (autoridades públicas, funcionários, administradores e avaliadores); iii) beneficiários diretos do ato ou omissão. ${ }^{183}$

Ao analisá-la sob o escopo da tutela do patrimônio cultural, Inês Virgínia Prado Soares afirma que a Ação Popular é

"um direito do cidadão de acesso à justiça jurisdicional, exercido individualmente. Este instrumento processual reflete o direito subjetivo ao patrimônio cultural, com o escopo de resguardá-lo. Ao mesmo tempo, abre espaço para a intervenção direta do cidadão,

\footnotetext{
${ }^{182}$ Cf. SOARES, Inês Virgínia Prado. Op. Cit. P.368

${ }^{183}$ Cf. RODRIGUES, Geisa de Assis. Ação Popular. In: DIDDIER JR., Fredie (org.). Ações Constitucionais. 4ạ ed.. Salvador: Ed. Forum, 2009. P. 280.
} 
em verdadeira possibilidade do exercício da cidadania participativa na correção das disfunções existentes nas tarefas de tutela do patrimônio cultural como bem pertencente à comunidade." 184

Com a finalidade de ilustrar a afirmação acima, será transcrita aqui uma decisão monocrática da Desembargadora Helena Cândida Lisboa Gaede, da Décima Quarta Câmara Cível do Tribunal de Justiça do Rio de Janeiro, no sentido de negar agravo de instrumento interposto contra decisão liminar em Ação Popular que paralisou obras que estavam descaracterizando o Abrigo de Bondes na cidade de Niterói. A Ação Popular pleiteava a ilegalidade da Lei Municipal no 2.090/2003 de Niterói, que permitiu, segundo as palavras utilizadas na inicial, à Empresa P.R.A. Empreendimentos e Participações Ltda. realizar obras de recuperação no Abrigo dos Bondes, "tombado em 1993, provisoriamente, em troca de lhe ter sido permitido construir um Hipermercado Guanabara junto ao Abrigo dos Bondes e no qual será instalado um centro cultural, com lojas, cinemas etc." Sua ementa é:

"Agravo de Instrumento. Abrigo dos Bondes. Imóvel tombado provisoriamente que se equipara a definitivo. Artigo 10 do Decreto-Lei no 25/1937. Construção de obra no local com base na Lei Municipal no 2.090/2003 de Niterói, objeto de Ação Popular que aponta a ilegalidade da lei, reconhecida no parecer do MP, por excluir limitações de imóvel tombado, criar área cultural de interesse urbanístico no imóvel e permitiu construções. Das fotografias do imóvel antigo e das projeções fotográficas do projeto evidencia-se a transformação do imóvel tombado em moderno. A descaracterização $\boldsymbol{e}$ o prosseguimento das obras tornar-se-iam um fato consumado em detrimento do patrimônio histórico. Incidência dos arts. 17 e 18 do Decreto-Lei no 25/1937 vedando as obras, admitidas pela Lei no 2.090/2003. Liminar de sustação das obras. Negado seguimento ao recurso na forma do art. 557, caput do CPC." ${ }^{185}$ (grifei)

\subsubsection{6 - Ação Civil Pública.}

A Ação Civil Pública, regida pela Lei no 7.347/1986 e pelo art. 129, inciso III, da $\mathrm{CF} / 88$, é um instrumento judicial que tutela, dentre outros bens jurídicos, bens culturais materiais e imateriais, móveis ou imóveis, públicos ou privados que estejam em território brasileiro.

\footnotetext{
184 Ibid. P. 368.

${ }^{185}$ TJRJ. A.I. n. 2008.002.35098. Rel. Des. Helena Gaede. Rio de Janeiro. 05 Novembro 2008.
} 
Inicialmente, a Lei no 7.347/1986 tutelava, além dos bens e direitos de valor artístico, estético, histórico, turístico e paisagístico (art. 1ํㅡ, inciso III), o meio ambiente (art. 1으, inciso I), o consumidor (art. 1으, inciso II) e qualquer outro interesse difuso ou coletivo (art. 1으, inciso IV). Entretanto, este último inciso fora vetado pelo então presidente da República sob o argumento de que a expressão "qualquer outro interesse difuso" geraria insegurança jurídica. Com o advento do Código de Defesa do Consumidor (Lei no 8.078/90), através de seu artigo 110, o dispositivo vetado foi restabelecido e ampliado.

Desta forma, a Ação Civil Pública tornou-se o instrumento judicial adequado para tutelar os interesses metaindividuais que abrangem os difusos e os coletivos strictu sensu, bem como os interesses individuais homogêneos, sem prejuízo da ação popular. A defesa do patrimônio cultural brasileiro é um dos interesses difusos que são, de acordo com a definição do art. 81, parágrafo único, inciso I do CDC, aqueles "transindividuais, de natureza indivisível, que sejam titulares pessoas indeterminadas e ligadas por circunstâncias de fato." Nas palavras de Rodolfo de Camargo Mancuso:

"Pode-se dizer que a ação civil pública, de natureza cominatória, tem por objeto uma pretensão visando uma obrigação de fazer, ou de não fazer, que recomponha in specie a lesão ao interesse metaindividual violado, sob pena de execução por terceiro, às suas expensas, ou de cominação de multa diária pelo retardamento no cumprimento específico do julgado. O interesse objetivado por referir-se ao meio ambiente, aos consumidores ou ao patrimônio público natural e cultural do País, lato sensu." ${ }^{186}$

De acordo com o artigo 5o da Lei no 7.347/1986, tem legitimidade para propor a Ação Civil Pública: o Ministério Público; a Defensoria Pública; a União, os Estados, o Distrito Federal e os Municípios; autarquia, empresa pública, fundação ou sociedade de economia mista; associação que concomitantemente esteja constituída há pelo menos um ano nos termos da lei civil (o $\S 4$ o do artigo em tela permite a dispensa deste requisito quando haja manifesto interesse social evidenciado pela dimensão ou característica do dano, ou pela relevância do bem jurídico a ser protegido) e inclua,

\footnotetext{
186 MANCUSO, Rodolfo de Camargo. Ação Civil Pública: em defesa do meio ambiente, do patrimônio cultural e dos consumidores. São Paulo: Ed. Revista dos Tribunais, 2007. P. 39.
} 
entre suas finalidades institucionais, a proteção ao meio ambiente, ao consumidor, à ordem econômica, à livre concorrência ou ao patrimônio artístico, estético, histórico, turístico e paisagístico. Sublinha-se que a proposição da Ação Civil Pública pelo Ministério Público é uma de suas funções institucionais, consoante o artigo 129, inciso III, da Constituição. Outrossim, o § 1으 do artigo 5o da Lei № 7.347/1986 estipula que caso o Ministério Público não intervenha no processo como parte, atuará obrigatoriamente como fiscal da lei.

A Lei ainda prevê, em seu artigo 18, que na Ação Civil Pública não haverá adiantamento de custas, emolumentos, honorários periciais e quaisquer outras despesas, nem condenação da associação autora, salvo se comprovada a má-fé, em honorários advocatícios, custas e despesas processuais. Na hipótese de condenação em dinheiro, o artigo 18 da Lei estabelece que a indenização pelo dano causado reverterá ao Fundo de Defesa dos Direitos Difusos ${ }^{187}$, que é regulado pelo Decreto no 1.306/1994, gerido por um Conselho Federal ou Conselhos Estaduais de que participarão necessariamente o Ministério Público e representantes da comunidade.

Insta aqui ser colocado que a Ação Civil Pública é o meio pelo qual se pode pleitear a implementação, o controle e o cumprimento de políticas públicas pela Administração, quando omissa, "de modo que o Judiciário possa resguardar conteúdo essencial dos direitos fundamentais dos cidadãos." 188 Cabe a este instrumento processual, portanto, "permitir que políticas públicas (saúde, educação, escola e queijandos) sejam determinadas em prol da efetividade da Constituição" ${ }^{189}$, tendo o Ministério Público relevante missão ao propô-la, pois, conforme bem advertido por Américo Bedê Freire Júnior, "no Brasil, a sociedade civil ainda não conseguiu se organizar a ponto de reivindicar atuação dos representantes eleitos pelo povo." 190

A implementação de políticas públicas culturais por via do instrumento processual em comento, o que é plausível diante do princípio da não taxatividade da

\footnotetext{
${ }^{187}$ O Fundo Nacional de Direitos Difusos é regulado pelo Decreto 1.306 de 09/11/1994.

${ }^{188}$ RODRIGUES, Marcelo Abelha. Ação Civil Pública. In: DIDIER JR., Fredie. Op. Cit. P. 363.

${ }^{189}$ FREIRE JÚNIOR, Américo Bedê. O controle judicial de políticas públicas. São Paulo: Ed. Revista dos Tribunais, 2005. P. 97.

190 Ibid. P. 98.
} 
Ação Civil Pública, foi objeto de análise pelo Supremo Tribunal Federal ou pelo Superior Tribunal de Justiça somente no que tange à preservação do patrimônio cultural brasileiro. Nada obsta, portanto, que uma Ação Civil Pública tenha por objeto a construção de centros culturais, bibliotecas, museus, etc. Neste diapasão, a efetivação do direito à saúde, outro direito fundamental que exige prestações positivas do Estado através da elaboração de políticas públicas, foi objeto de litígio em diversas ocasiões. Assim se manifestou o Supremo Tribunal Federal ao julgar o Agravo Regimental no Agravo de Instrumento que admitiu Recurso Extraordinário em Ação Civil Pública, movida pelo Ministério Público do Estado do Paraná, que pleiteava a liberação de recursos financeiros pelo Estado do Paraná para a ampliação da unidade de terapia intensiva-adulta do Hospital Universitário de Londrina:

"DIREITO CONSTITUCIONAL. DIREITO À SAÚDE. AGRAVO REGIMENTAL EM AGRAVO DE INSTRUMENTO. IMPLEMENTAÇÃO DE POLÍTICAS PÚBLICAS. AÇÃO CIVIL PÚBLICA. PROSSEGUIMENTO DE JULGAMENTO. AUSÊNCIA DE INGERENNCIA NO PODER DISCRICIONÁRIO DO PODER EXECUTIVO. ARTIGOS 2, 60 E 196 DA CONSTITUIÇÃO FEDERAL. 1. O direito à saúde é prerrogativa constitucional indisponível, garantido mediante a implementação de políticas públicas, impondo ao Estado a obrigação de criar condições objetivas que possibilitem o efetivo acesso a tal serviço. 2. É possível ao Poder Judiciário determinar a implementação pelo Estado, quando inadimplente, de políticas públicas constitucionalmente previstas, sem que haja ingerência em questão que envolve o poder discricionário do Poder Executivo. Precedentes. 3. Agravo regimental improvido." ${ }^{191}$ (grifei)

Por fim, insta frisar que a evocação da cláusula da "Reserva do Possível", um tema polêmico que não cabe ser aprofundado aqui, não poderá servir de escusa por parte da Administração Pública para a efetivação de um direito fundamental, conforme o posicionamento do Supremo Tribunal Federal:

"Agravo regimental no agravo de instrumento. Constitucional. Legitimidade do Ministério Público. Ação civil pública. Implementação de políticas públicas. Possibilidade. Violação do princípio da separação dos poderes. Não ocorrência. Reserva do possível. Invocação. Impossibilidade. Precedentes. 1. Esta Corte já firmou a orientação de que o Ministério Público detém legitimidade para requerer, em Juízo, a implementação de políticas públicas por parte do Poder Executivo de molde a assegurar a concretização de direitos difusos, coletivos e individuais homogêneos garantidos pela Constituição Federal, como é o caso do acesso à saúde. 2. O Poder Judiciário, em situações excepcionais, pode determinar que a Administração pública adote medidas

${ }^{191}$ STF. Ag. Reg. No A.I. no 734.487/PR. Rel. Min. Ellen Gracie. Brasília, 03 agosto 2010. 
assecuratórias de direitos constitucionalmente reconhecidos como essenciais sem que isso configure violação do princípio da separação de poderes. 3. A Administração não pode invocar a cláusula da "reserva do possível" a fim de justificar a frustração de direitos previstos na Constituição da República, voltados à garantia da dignidade da pessoa humana, sob o fundamento de insuficiência orçamentária. 4. Agravo regimental não provido. " 192 (grifei)

${ }^{192}$ STF. Ag. Reg. No A.I. no 674764/PI. Rel. Min. Dias Toffoli. Brasília, 04 outubro 2011. 


\section{Políticas Públicas Culturais no Governo Lula. A Reforma da Lei Rouanet e a Busca pela Democratização Cultural.}

"Não cabe ao Estado fazer cultura, mas, sim, criar condições de acesso universal aos bens simbólicos. Não cabe ao Estado fazer cultura, mas, sim, proporcionar condições necessárias para a criação e a produção de bens culturais, sejam eles artefatos ou mentefatos. Não cabe ao Estado fazer cultura, mas, sim, promover o desenvolvimento cultural geral da sociedade. Porque o acesso à cultura é um direito básico de cidadania, assim como o direito à educação, à saúde, à vida num meio ambiente saudável. Porque, ao investir nas condições de criação e produção, estaremos tomando uma iniciativa de consequências imprevisíveis, mas certamente brilhantes e profundas - já que a criatividade popular brasileira, dos primeiros tempos coloniais aos dias de hoje, foi sempre muito além do que permitiam as condições educacionais, sociais e econômicas de nossa existência. (...) toda política cultural faz parte da cultura política de uma sociedade e de um povo, num determinado momento de sua existência. No sentido de que toda política cultural não pode deixar nunca de expressar aspectos essenciais da cultura desse mesmo povo. Mas, também, no sentido de que é preciso intervir. Não segundo a cartilha do velho modelo estatizante, mas para clarear caminhos, abrir clareiras, estimular, abrigar. Para fazer uma espécie de "do-in" antropológico, massageando pontos vitais, mas momentaneamente desprezados ou adormecidos, do corpo cultural do país. (...) As políticas públicas para a cultura devem ser encaradas, também, como intervenções, como estradas reais e vicinais, como caminhos necessários, como atalhos urgentes. Em suma, como intervenções criativas no campo do real histórico e social. Daí que a política cultural deste Ministério, a política cultural do Governo Lula, a partir deste momento, deste instante, passa a ser vista como parte do projeto geral de construção de uma nova hegemonia em nosso País. Como parte do projeto geral de construção de uma nação realmente democrática, plural e tolerante. Como parte e essência de um projeto consistente e criativo de radicalidade social. Como parte $e$ essência da construção de um Brasil de todos. "193

\section{1. - Políticas Culturais no Governo Lula e as Gestões de Gilberto Gil e Juca Ferreira no Ministério da Cultura.}

No ano de 2002 tomou posse o Presidente Luis Inácio Lula da Silva, brasileiro nascido no interior do Estado de Pernambuco e ex-líder sindical no ABC Paulista nos anos 1970/80. Foi a primeira vez na História do Brasil que um representante de um partido de esquerda tomou posse do Poder Executivo Federal. Diferentemente do seu antecessor, o governo Lula foi marcado pela participação social na elaboração de políticas públicas através de mecanismos de democracia participativa na administração

\footnotetext{
${ }^{193}$ GIL, Gilberto. Discurso de posse do Ministro da Cultura proferido em 02/01/2003. Disponível em <http://www1.folha.uol.com.br/folha/brasil/ult96u44344.shtml>. Acesso em 20 out. 2011.
} 
pública (conferências, seminários, escutas públicas à população entre outros meios participativos).

O Ministério da Cultura ficou a cargo do tropicalista Gilberto Gil, cantor e compositor baiano detentor de uma extensa e reconhecida obra, que ficou na pasta até agosto de 2008, quando tomou posse o então Secretário Executivo Juca Ferreira. O discurso de posse de Gil, proferido em 02 de janeiro de 2003, reproduzido em parte na abertura do presente capítulo, foi o primeiro de uma série de "discursos programáticos" que apontam uma mudança de paradigma das políticas públicas culturais e uma reformulação que viria ocorrer no âmbito do Ministério da Cultura durante o mandato do Presidente Lula. Ainda em seu discurso de posse, Gilberto Gil afirma que o Ministério da Cultura deve estar "presente em todos os cantos e recantos de nosso país" sendo "a casa de todos os que pensam e fazem o Brasil (...) a casa da cultura brasileira". Segundo Isaura Botelho, o Ministério da Cultura com Gilberto Gil à sua frente "deu início a um intenso processo de discussão e reorganização do papel do Estado na área cultural." ${ }^{194}$ Foi iniciada a luta pelo aumento do orçamento da pasta, que até hoje nunca atingiu $1 \%$ do orçamento da União, o ideal sugerido pela UNESCO, bem como pela sua melhor distribuição no território nacional. Buscou-se obter um equilíbrio regional, afastando desta maneira as políticas "de balcão" e clientelistas vigentes durante o período $\mathrm{FHC} /$ Weffort.

Entre as mudanças promovidas no Ministério da Cultura durante a gestão Gil/Juca, devem ser destacadas:

"1) o alargamento do conceito de cultura e a inclusão do direito à cultura, como um dos princípios basilares da cidadania; sendo assim 2) o público alvo das ações governamentais é deslocado do artista para a população em geral; e 3) o Estado, então, retoma o seu lugar como agente principal na execução das políticas culturais; ressaltando a importância da 4) participação da sociedade na elaboração dessas políticas; e 5) a divisão de responsabilidades entre os diferentes níveis de governo, as organizações sociais e a sociedade, para a gestão de ações." ${ }^{195}$

\footnotetext{
194 BOTELHO, Isaura. A política cultural e o plano das ideias. P. 16. Disponível em <http://www.cult.ufba.br/enecult2007/IsauraBotelho.pdf>. Acesso em 20 out. 2011.

195 SOTO, Cecília et al.. Políticas públicas de cultura: os mecanismos de participação social. In: RUBIM, Antonio Albino Canelas (org). Políticas Culturais no Governo Lula. Salvador: UFBA, 2010. P. 30.
} 
O Ministério da Cultura herdou de sua gestão anterior a política pública cultural baseada nos já estudados modelos de financiamento previstos na Lei Rouanet, bem como suas instituições vinculadas. Este período de transição contou também com a Secretaria do Audiovisual, a Secretaria do Livro e da Leitura, a Secretaria da Música e Artes Cênicas e a Secretaria do Patrimônio, Museus e Artes Plásticas. Através do Decreto $\mathrm{n}$ - 4.805, de 12 de agosto de 2.003, ocorreu uma reformulação institucional do MinC, quando criadas a Secretaria de Políticas Culturais, a Secretaria de Fomento e Incentivo à Cultura, a Secretaria de Programas e Projetos Culturais, a Secretaria de Identidade e Diversidade Cultural (hoje Secretaria de Cidadania Cultural), sendo mantida a Secretaria do Audiovisual. A Agência Nacional do Cinema - ANCINE, criada em 2001 e inicialmente vinculada ao Ministério do Desenvolvimento, Indústria e Comércio Exterior, passou a ser vinculada ao Ministério da Cultura que, por sua vez, tentou transformá-la na Agência Nacional de Cinema e Audiovisual - ANCINAV. No entanto, tal projeto não foi à frente, haja vista que a ANCINAV regularia também os conteúdos da televisão (aberta e por assinatura) e da internet, confrontando, assim, os interesses dos grandes poderes midiáticos brasileiros.

Desde 2009, o Ministério da Cultura possui o seguinte quadro de entes vinculados: o Instituto do Patrimônio Histórico e Artístico Nacional - IPHAN, a Agência Nacional de Cinema - ANCINE, a Biblioteca Nacional - BN, a Fundação Casa de Rui Barbosa - FCRB, a Fundação Nacional de Artes - FUNARTE, a Fundação Cultural Palmares - FCP e o Instituto Brasileiro de Museus - IBRAM. O Ministério da Cultura e suas entidades vinculadas são os integrantes do Sistema Federal de Cultura - SFC, criado durante a gestão de Gilberto Gil, e tido como a primeira etapa para a formação do Sistema Nacional de Cultura - SNC. As finalidades do Sistema Federal de Cultura encontram-se delineadas no artigo 1 을 do Decreto no 5.520/2005. ${ }^{196}$

\footnotetext{
196 "Art. $1^{\text {- }}$ Fica instituído o Sistema Federal de Cultura - SFC, com as seguintes finalidades: I - integrar os órgãos, programas e ações culturais do Governo Federal; II-contribuir para a implementação de políticas culturais democráticas e permanentes, pactuadas entre os entes da federação e sociedade civil; III - articular ações com vistas a estabelecer e efetivar, no âmbito federal, o Plano Nacional de Cultura; $e$ $I V$ - promover iniciativas para apoiar o desenvolvimento social com pleno exercício dos direitos culturais $e$ acesso às fontes da cultura nacional".
} 
Fruto da gestão participativa adotada pelo Ministério da Cultura, o seminário "Cultura Para Todos", realizado no ano de 2003 em diferentes regiões do Brasil, foi o "primeiro passo de uma série de ações voltadas ao envolvimento dos cidadãos na avaliação e direcionamento dos rumos das políticas culturais." ${ }^{197}$ Nele, os participantes deveriam responder quais eram os principais entraves para o acesso ao financiamento público federal da cultura e que mecanismos deveriam ser adotados para garantir a transparência, a democratização e a descentralização do financiamento público da cultura. Importante ação do Ministério foi a realização das Conferências Nacionais de Cultura em 2005 e 2010, que, de acordo com Lia Calabre, "[constituíram] uma inovação no campo da participação social mais ampla". ${ }^{198}$ As resoluções da $1^{\text {ạ }}$ Conferência Nacional de Cultura serviram como subsídios para o Projeto de Lei do Plano Nacional de Cultura - PNC e do desenvolvimento de suas diretrizes gerais.

A seguir serão abordados, além do programa Cultura Viva, os três movimentos que tiveram papéis prioritários durante a elaboração de políticas públicas culturais no governo Lula: o Plano Nacional de Cultura, o Sistema Nacional de Cultura e a aprovação da PEC no 150/2003. Serão também abordadas as demais Propostas de Emenda à Constituição (PECs) e Projetos de Lei (PLs) que versam sobre matéria cultural, destacando-se o PL no 6.722/2010, que revoga a Lei Rouanet e institui o Programa Nacional de Fomento e Incentivo à Cultura - Procultura.

\subsection{1. - Programa Nacional de Cultura, Educação e Cidadania - Cultura Viva.}

Idealizado pelo historiador e Secretário da Cidadania Cultural do Ministério da Cultura entre 2004 e 2010, Célio Turino, e constituído pela Portaria Ministerial no 156, de 06 de julho de 2004, o Programa Nacional de Cultura, Educação e Cidadania- Cultura Viva tem como objetivo "promover o acesso aos meios de fruição, produção e difusão

\footnotetext{
${ }^{197}$ MINISTÉRIO DA CULTURA. Plano Nacional de Cultura: Diretrizes Gerais. 2ª Ed. Brasília: Ministério da Cultura, 2008. P. 17.

${ }^{198}$ CALABRE, Lia. Op. Cit. P. 120.
} 
cultural, assim como potencializar energias sociais e culturais, visando à construção de novos valores de cooperação e solidariedade", estimulando, desta forma, "a exploração, o uso e a apropriação dos códigos, linguagens artísticas e espaços públicos e privados que possam ser disponibilizados para a ação cultural." 199 O programa, que contribui para o "enfrentamento de problemas relativos às carências de instrumentos e estímulos para a produção e circulação da expressão da cultura local" ${ }^{200}$, é destinado à populações de baixa renda; estudantes da rede básica de ensino; comunidades indígenas, rurais e quilombolas; agentes culturais, artistas, professores e militantes que desenvolvem ações no combate à exclusão social e cultural. ${ }^{201}$

O Cultura Viva engloba cinco ações: Agentes Cultura Viva, Cultura Digital, Escola Viva, os Griôs-Mestres dos Saberes e os Pontos de Cultura, sendo esta última a ação prioritária do programa. Nas palavras empregadas no site do Ministério da Cultura, os Pontos de Cultura são

"entidades reconhecidas e apoiadas financeira e institucionalmente pelo Ministério da Cultura que desenvolvem ações de impacto sociocultural em suas comunidades. (...) $O$ ponto de Cultura não tem um modelo único, nem de instalações físicas, nem de programação ou atividade. Um aspecto comum a todos é a transversalidade da cultura. A proposta é que, a partir desse ponto, desencadeia-se um processo orgânico agregando novos agentes e parceiros e identificando novos pontos de apoio: a escola mais próxima, o salão da igreja, a sede da sociedade de amigos do bairro, ou mesmo a garagem de algum voluntário." 202

Em depoimento dado sobre os Pontos de Cultura no ano de 2007, o Ministro Gilberto Gil averigua a finalidade da ação ao dizer que:

"Se você investe em um mestre de capoeira, ou em um grupo de maracatu, ou em um poeta popular, isso é considerado como gasto. Não é [gasto], é investimento. É igual a você fazer um quilômetro de asfalto, ou mais ainda, porque, como dizia o presidente Lula, você está investindo em gente, você está investindo em Homem." 203

\footnotetext{
${ }^{199}$ Artigos 1ㅇ e 2ㅇ da Portaria Ministerial nำ156/2004.

200 SILVA, Frederico A. Barbosa; ARAÚJO, Herton Ellery (org.). Cultura Viva: avaliação do programa arte educação e cidadania. Brasília: Ipea, 2010. P. 38.

201 Artigo 3o da Portaria Ministerial no156/2004.

202 MINISTÉRIO DA CULTURA. Ponto de Cultura. Disponível em <http://www.cultura.gov.br/culturaviva/ponto-de-cultura/>. Acesso em 20 out. 2011.

${ }^{203}$ Vídeo disponível em <http://www.youtube.com/watch?v=WPW5Gnq-VtA>. Acesso em 20 out. 2011.
} 
A execução do Programa Cultura Viva é realizada através de editais que convidam organizações privadas e instituições públicas, legalmente constituídas, de caráter cultural e social, sendo as não governamentais sem fins lucrativos, a apresentarem propostas para participação e parceria em seus cinco eixos. ${ }^{204}$ Os recursos para sua implementação são oriundos da Lei Orçamentária Anual (LOA) e de parcerias agregadas ao programa. ${ }^{205}$ No que diz respeito aos Pontos de Cultura, quando firmado o convênio, cada Ponto receberá $\mathrm{R} \$ 185.000,00$ (cento e oitenta e cinco mil reais) em cinco parcelas semestrais para que invista de acordo com o projeto apresentado, podendo desenvolvê-lo através da compra de materiais (principalmente os de natureza multimídia), contratação de profissionais etc. Em abril de 2010, havia cerca de quatro mil Pontos de Cultura distribuídos em 1122 Municípios do Brasil. No entanto, diversos Pontos de Cultura ainda apresentam dificuldades para interpretar e se adequar às normas federais que regulam a transferência de recursos e as prestações de contas, deflagrando-se, assim, um paradoxo onde a própria lei se torna uma barreira para a efetivação de um direito fundamental. Tendo em vista a finalidade do programa e a quem ele se destina, os "ponteiros" vem, nos últimos anos, reivindicando perante o poder público outro modelo para prestação de contas que não seja regido pela Lei no 8.666/1993.

O Cultura Viva, no ano de 2011, ainda é apenas um programa do Ministério da Cultura. Atualmente, está em trâmite na Câmara dos Deputados o Projeto de Lei no 757/2011, de autoria da deputada federal Jandira Feghali (PCdoB - RJ), que institucionaliza o Cultura Viva, estabelece normas para seu funcionamento e dá outras providências. Somente após a sanção presidencial, o Projeto Cultura Viva será consolidado como Política de Estado. Antes disto, caberá à Sociedade Civil acompanhar o trâmite do Projeto de Lei em comento e participar das audiências públicas que o debatam.

\footnotetext{
${ }^{204}$ Artigo 4ㅇ da Portaria Ministerial no 156/2004.

${ }^{205}$ Artigo 5ㅇ da Portaria Ministerial nำ156/2004.
} 


\subsection{2. - O Plano Nacional de Cultura - PNC e o Sistema Nacional de Cultura - SNC.}

O Plano Nacional de Cultura - PNC foi instituído através da Emenda Constitucional no 48/2005, que acrescentou o § 3ำ ao artigo 215 da Constituição Federal de 1988, cuja redação é:

"§ 3 A lei estabelecerá o Plano Nacional de Cultura, de duração plurianual, visando ao desenvolvimento cultural do País e à integração das ações do poder público que conduzem à: I - defesa e valorização do patrimônio cultural brasileiro; II - produção, promoção e difusão de bens culturais; III- formação de pessoal qualificado para a gestão da cultura em suas múltiplas dimensões; IV - democratização do acesso aos bens de cultura; $V$ - valorização da diversidade étnica e regional."

Embora a Proposta de Emenda à Constituição que institui o Plano Nacional de Cultura tenha sido apresentada no ano 2000 pelo Deputado Federal Gilmar Machado (PEC no 306), durante o governo FHC, foi somente a partir do mandato de Lula que o Plano Nacional de Cultura se tornou um compromisso. Entre 2003 e 2010 foi trilhado por toda sociedade um "complexo percurso de construção coletiva do $P N C^{\prime \prime}{ }^{206}$, por onde foram realizados o Seminário Cultura Para Todos (2003), as Câmaras Setoriais (2004), duas Conferências Nacionais de Cultura (2005 e 2009), Seminários Estaduais e Fóruns Virtuais, parcerias entre o Ministério da Cultura e o Ipea e o IBGE (2006 e 2007) e a elaboração das diretrizes gerais do PNC. No caderno elaborado pelo Ministério da Cultura, que continha as Diretrizes Gerais do Plano Nacional de Cultura, constavam cinco estratégias gerais: fortalecer a ação do Estado no planejamento e na execução das políticas culturais; incentivar, proteger e valorizar a diversidade artística e cultural brasileira; universalizar o acesso dos brasileiros à fruição e produção cultural; ampliar a participação da cultura no desenvolvimento econômico sustentável e consolidar os sistemas de participação social na gestão de políticas culturais. ${ }^{207}$

Aprovado no apagar das luzes do governo Lula, o Plano Nacional de Cultura (Lei no 12.343 de 2 de dezembro de 2010) possui uma importância histórica, social e política fundamental. Segundo a pesquisadora Paula Félix dos Reis,

\footnotetext{
${ }^{206}$ MINISTÉRIO DA CULTURA. Op. Ct. P. 17.

207 Ibid. P. 61 e seguintes.
} 
"se trata do primeiro planejamento do governo voltado para o setor da cultura que tem como diferencial o fato de [ter sido] elaborado juntamente com a sociedade. Não só por isso, mas principalmente porque possibilita uma intervenção do Estado, em todas as suas instâncias (federal, estadual e municipal) e divisões do poder (executivo, legislativo e judiciário) de uma forma planejada, com melhor distribuição de recursos $e$ articulações do governo entre si e com os segmentos artísticos e culturais." ${ }^{208}$

O Plano é um instrumento de fortalecimento institucional, bem como de planejamento, definição e implementação de políticas públicas culturais a longo prazo, haja vista que contém diretrizes, estratégias e ações norteadoras para tais políticas até o ano de 2020. ${ }^{209}$ De acordo com a lei que o instituiu, seus objetivos são: reconhecer e valorizar a diversidade cultural, étnica e regional brasileira; proteger e promover o patrimônio histórico e artístico, material e imaterial; valorizar e difundir as criações artísticas e os bens culturais; promover o direito à memória por meio dos museus, arquivos e coleções; universalizar o acesso à arte e à cultura; estimular a presença da arte e da cultura no ambiente educacional; estimular o pensamento crítico e reflexivo em torno dos valores simbólicos; estimular a sustentabilidade socioambiental; desenvolver a economia da cultura, o mercado interno, o consumo cultural e a exportação de bens, serviços e conteúdos culturais; reconhecer os saberes, conhecimentos e expressões tradicionais e os direitos de seus detentores; qualificar a gestão na área cultural nos setores público e privado; profissionalizar e especializar os agentes e gestores culturais; descentralizar a implementação das políticas públicas de cultura; consolidar processos de consulta e participação da sociedade na formulação das políticas culturais; ampliar a presença e o intercâmbio da cultura brasileira no mundo contemporâneo; articular e integrar sistemas de gestão cultural. ${ }^{210}$

O Plano Nacional de Cultura apresenta 275 ações de onde foram elaboradas 48 metas pelo Conselho Nacional de Política Cultural- CNPC sobre cinco eixos temáticos: o papel do Estado; a diversidade artística e cultural; o acesso à cultura; o

\footnotetext{
${ }^{208}$ REIS, Ana Paula Félix. O Processo de Elaboração da Política Nacional de Cultura na Gestão do Ministro Gil. P. 15-16. Disponível em <http://www.cult.ufba.br/enecult2008/14381.pdf>. Acesso em 21 out. 2011.

209 Cf. MINISTÉRIO DA CULTURA. Plano Nacional de Cultura. Disponível em $<$ http://www.cultura.gov.br/site/2011/05/27/plano-nacional-de-cultura-22/>.

${ }^{210}$ Artigo 20 da Lei no $12.323 / 2010$.
} 
desenvolvimento socioeconômico sustentável e a participação social. Será objeto de revisão constante, sendo que a primeira ocorrerá em 2014, quatro anos, portanto, após a promulgação da lei que o instituiu.

Entre 21 de setembro e 21 de outubro de 2011, o Ministério da Cultura abriu consulta pública para a elaboração das metas do Plano Nacional de Cultura. Foi permitido à sociedade civil e aos gestores públicos que contribuíssem para o debate acerca das metas, através do site do próprio Ministério e de eventos realizados durante este período. O Conselho Nacional de Política Cultural - CNPL validará as metas debatidas no final de 2011 e publicá-las-á no Diário Oficial da União em 2012.

O § 10 do artigo 3으 da Lei № 12.323/2010 estipulou que o "Sistema Nacional de Cultura - SNC, criado por lei específica, será o principal articulador federativo do PNC, estabelecendo mecanismos de gestão compartilhada entre os entes federados e a sociedade civil". Contudo, o Sistema Nacional de Cultura, que funcionará de maneira análoga ao Sistema Único de Saúde - SUS, ainda se encontra em fase de construção em todo o País. Deve ser posto aqui que a PEC que o institui ( $n=416 / 2005$ ) não foi aprovada até o término da presente monografia.

Francisco Humberto Cunha Filho reconhece a necessidade de um sistema nacional de cultura diante da sobreposição de tarefas no âmbito cultural entre a União, Estados e Municípios e o desprestígio de organizações culturais nos níveis da política participativa e da representação de interesses:

"Impõe-se, por conseguinte, a correção de tais anomalias, com a construção de um adequado sistema nacional da cultura que contemple os objetivos básicos de evitar ações repetidas, otimizar os recursos e implementar as vocações de cada um dos entes da federação, a partir da lição básica de organização dos Estados complexos, qual seja, a de competir à União ações culturais de interesse nacional, bem como aquelas que perpassem as divisas de mais de um Estado; do mesmo modo, deve-se atribuir aos Estados as ações culturais de interesse de todo o seu território ou população, bem como aquelas que extrapolem os limites de mais de um município; a estes, os Municípios, por fim, as responsabilidades sobre as ações culturais basicamente de interesse local." 211

Frederico A. Barbosa da Silva complementa a afirmação acima:

${ }^{211}$ CUNHA FILHO, Francisco Humberto. Op. Cit. P. 163. 
"Não há legislação específica que trate da repartição de responsabilidades ou competências no investimento e financiamento de ações pelos entes de governo na área cultural. A legislação brasileira afirma, de forma geral, a importância do setor público em todas as suas dimensões no fomento à produção, difusão e preservação cultural. (...) A criação de um sistema nacional e descentralizado representa o reconhecimento da autonomia das três esferas de governo na execução ou fomento de ações culturais, e também dos efeitos sinérgicos e potencializadores na atuação conjunta." 212

O Acordo de Cooperação Federativa é documento a ser firmado entre a União e os demais entes federativos e que visa ao desenvolvimento do Sistema Nacional de Cultura no país. Nele estão definidos os objetivos do Sistema Nacional de Cultura, que são: articular os entes federados visando ao desenvolvimento de políticas, programas, projetos e ações conjuntas no campo da cultura; estabelecer um processo democrático de participação na gestão das políticas e dos recursos públicos na área cultural; promover a articulação e implementação de políticas públicas que promovam a interação da cultura com as demais áreas sociais, destacando seu papel estratégico no processo de desenvolvimento; promover o intercâmbio entre os entes federados para a formação, capacitação e circulação de bens e serviços culturais, viabilizando a cooperação técnica entre estes; criar instrumentos de gestão para acompanhamento e avaliação das políticas públicas de cultura desenvolvidas no âmbito do SNC; e estabelecer parcerias entre os setores público e privado nas áreas de gestão e de promoção da cultura. $^{213}$

No mesmo documento, os partícipes assumem os seguintes compromissos: a implantação dos Sistemas Setoriais de Cultura, com vistas à articulação e integração das diversas áreas da cultura brasileira, atendendo sempre os princípios de participação e controle social; a elaboração e efetivação dos planos de cultura nas respectivas esferas de competência; a realização de conferências de cultura no âmbito de suas competências, para fortalecimento do processo participativo de discussão de

\footnotetext{
212 BARBOSA DA SILVA, Frederico A. Economia e Política Cultural: acesso, emprego e financiamento. Brasília: Ministério da Cultura, 2007. P. 254 e 258.

213 Cláusula Quarta do Acordo de Cooperação Federativa. Disponível em $<$ http://blogs.cultura.gov.br/snc/2011/09/01/acordos-federativos-arquivos/>.
} 
políticas públicas de cultura; o fortalecimento, a integração e a otimização dos mecanismos de financiamento específicos para cultura, nas suas esferas administrativas; a criação, instalação, implementação e/ou fortalecimento de um processo participativo de formulação de políticas públicas de cultura, estimulando a criação de Fóruns, Colegiados e Conselhos de Política Cultural, que atuarão de forma integrada; a criação e implantação, ou manutenção de órgão específico de gestão da política cultural em sua esfera administrativa; a criação e implementação de comissões intergestoras para operacionalização do Sistema Nacional de Cultura; a implantação e publicização do Sistema Nacional de Informações e Indicadores Culturais; a integração de programas e projetos de capacitação e aprimoramento de setores e instituições culturais específicos; e o fomento ao fluxo de projetos em circuitos culturais. ${ }^{214}$

Até 17 de outubro de 2011, o Distrito Federal, 8 Estados e 623 Municípios assinaram o Acordo de Cooperação Federativa ${ }^{215}$, o que implica dizer que há um longo trajeto a ser trilhado para a institucionalização e pleno funcionamento do Sistema Nacional de Cultura, que, por seu turno, deverá ser regulado por lei ordinária (PEC no $416 / 2005)$.

\subsection{3. - Propostas de Emendas à Constituição (PECs) e Projetos de Lei (PLs) que Versam sobre Matéria Cultural.}

O presente subitem busca fazer um breve levantamento sobre os principais Projetos de Lei (PLs) e Propostas de Emenda Constitucional (PECs), que foram apresentados durante o governo Lula e que até outubro de 2011 ainda não foram aprovados, com exceção das já abordadas PEC no 416/2005 e PL no 757/2011.

a) PEC 150/2003: Uma das principais lutas da gestão Gil/Ferreira foi o aumento do orçamento do Ministério da Cultura, que nunca atingiu 1\% do orçamento total da

\footnotetext{
${ }^{214}$ Cláusula Quinta do Acordo de Cooperação Federativa.

215 Dados obtidos em <http://blogs.cultura.gov.br/snc/files/2011/10/Relacao-dos-Estados_17-102011.pdf>. Acesso em 21 de out. 2011.
} 
União, o percentual considerado ideal pela UNESCO. Em 2011, após corte orçamentário no Governo Dilma Roussef, o Ministério da Cultura teve um dos menores orçamentos entre os Ministérios: R\$ 2,13 bilhões. Caso a PEC 150/2003 venha a ser aprovada, a exemplo do que está previsto na Constituição Federal de 1988 no que tange aos recursos a serem destinados à saúde e à educação, será acrescentado o artigo 216-A que determina que a União deverá aplicar anualmente nunca menos de $2 \%$, os Estados e o Distrito Federal, 1,5\%, e os Municípios, 1 \%, da receita resultante de impostos, compreendida aquela proveniente de transferências, na preservação do patrimônio cultural brasileiro e na produção e difusão da cultura nacional. Dos $2 \%$, a União destinará 25\% aos Estados e ao Distrito Federal, e 25\% aos Municípios. De acordo com o texto da PEC, Lei Complementar definirá o rateio dos recursos destinados aos Estados, Distrito Federal e Municípios, observada a contrapartida de cada ente.

b) PEC 49/2007: Caso aprovada, a cultura será acrescentada ao artigo 6o da Constituição Federal de 1988, dispositivo que define os direitos sociais. Na sua atual redação, o artigo em comento define os direitos sociais como sendo a educação, a saúde, a alimentação, o trabalho, a moradia, o lazer, a segurança, a previdência social, a proteção à maternidade e à infância, a assistência aos desamparados. José Afonso da Silva reconhece que, embora os direitos culturais não estejam arrolados como uma espécie de direito social no artigo 6으, eles não perdem sua característica, pois "se a educação o foi, aí também estarão aqueles, até porque estão explicitamente referidos no art. $215^{\prime \prime 216}$ da Constituição.

c) PL no 5798/2009: O projeto de lei em comento, que foi uma das principais bandeiras da candidatura de Dilma Roussef à Presidência da República, institui o Programa de Cultura do Trabalhador e cria o Vale-Cultura. De acordo com o PL no 5798/2009, o Programa do Trabalhador, destinado a fornecer aos trabalhadores meios para o exercício dos direitos culturais e acesso às fontes de cultura, terá como objetivos

${ }^{216}$ SILVA, José Afonso da. Op. Cit. P. 314. 
possibilitar o acesso e a fruição dos produtos e serviços culturais; estimular a visitação a estabelecimentos culturais e artísticos; e incentivar o acesso a eventos e espetáculos culturais e artísticos. O projeto também prevê a criação do Vale-Cultura, cujo suporte será um cartão magnético, no âmbito do Programa de Cultura do Trabalhador. Com o Vale-Cultura, os trabalhadores de carteira assinada que recebem até cinco salários mínimos serão beneficiados com $\mathrm{R} \$ 50,00$ (cinquenta reais) para fins de consumo de produtos culturais (CDs, DVDs, peças de teatro, filmes, espetáculos de dança, museus, etc.). Após a aprovação da Lei, deverá o Poder Executivo regulamentá-la no prazo de sessenta dias após sua publicação.

O PL no 6722/2010, que revoga a Lei Rouanet e institui o Programa Nacional de Fomento e Incentivo à Cultura - Procultura, será objeto de estudo no subitem a seguir.

\section{2 - A Reforma da Lei Rouanet e a Busca pela Democratização Cultural.}

Uma pesquisa realizada pelo IBGE em $2008^{217}$ trouxe dados alarmantes sobre a realidade cultural brasileira: apenas $13 \%$ dos brasileiros frequentam cinema alguma vez por ano; $92 \%$ dos brasileiros nunca frequentaram museus; $93,4 \%$ dos brasileiros jamais frequentaram alguma exposição de arte; $78 \%$ dos brasileiros nunca assistiram a espetáculo de dança, embora 28,8\% saiam para dançar; mais de $90 \%$ dos municípios não possuem salas de cinema, teatro, museus e espaços culturais multiuso; o brasileiro lê em média 1,8 livros per capita/ano; 73\% dos livros estão concentrados nas mãos de apenas $16 \%$ da população; e o preço médio do livro de leitura corrente era de $R \$ 25,00$, considerado elevadíssimo se comparado com a renda do brasileiro nas classes C/D/E. Diante deste quadro, a busca pela democratização cultural tornou-se uma agenda prioritária durante a gestão Gilberto Gil/Juca Ferreira.

A Lei Rouanet, em seus 20 anos de vigência, foi o principal instrumento de apoio à atividade cultural do país. Por outro lado, causou enormes distorções quanto à distribuição da verba para a cultura no território brasileiro. De acordo com dados do

\footnotetext{
${ }^{217}$ Dados disponíveis em <http://mais.cultura.gov.br/2009/02/10/434/>. Acesso em 24 out. 2011.
} 
Ministério da Cultura, tomando como base o ano de 2007, a região Sudeste captou $80,16 \%$ dos recursos da Lei Rouanet via renúncia fiscal, enquanto as demais regiões captaram 19,84\%. Nas regiões Sul e Sudeste, os investimentos por via de renúncia fiscal superaram os realizados por meio de recursos orçamentários, enquanto nas regiões Norte, Nordeste e Centro-Oeste ocorreu o contrário: os recursos oriundos do Fundo Nacional de Cultura superaram aqueles via renúncia fiscal. A Revista Observatório Itaú Cultural, com base nos dados divulgados pelo Ministério da Cultura, elaborou um gráfico e uma tabela que ilustram a centralização da distribuição de recursos da Lei Rouanet entre os anos de 2002 e 2007. Também neles constam a população de cada estado da Federação e a quantidade de empresas tributadas com base no lucro real: ${ }^{218}$

\section{Mapa no 1:}

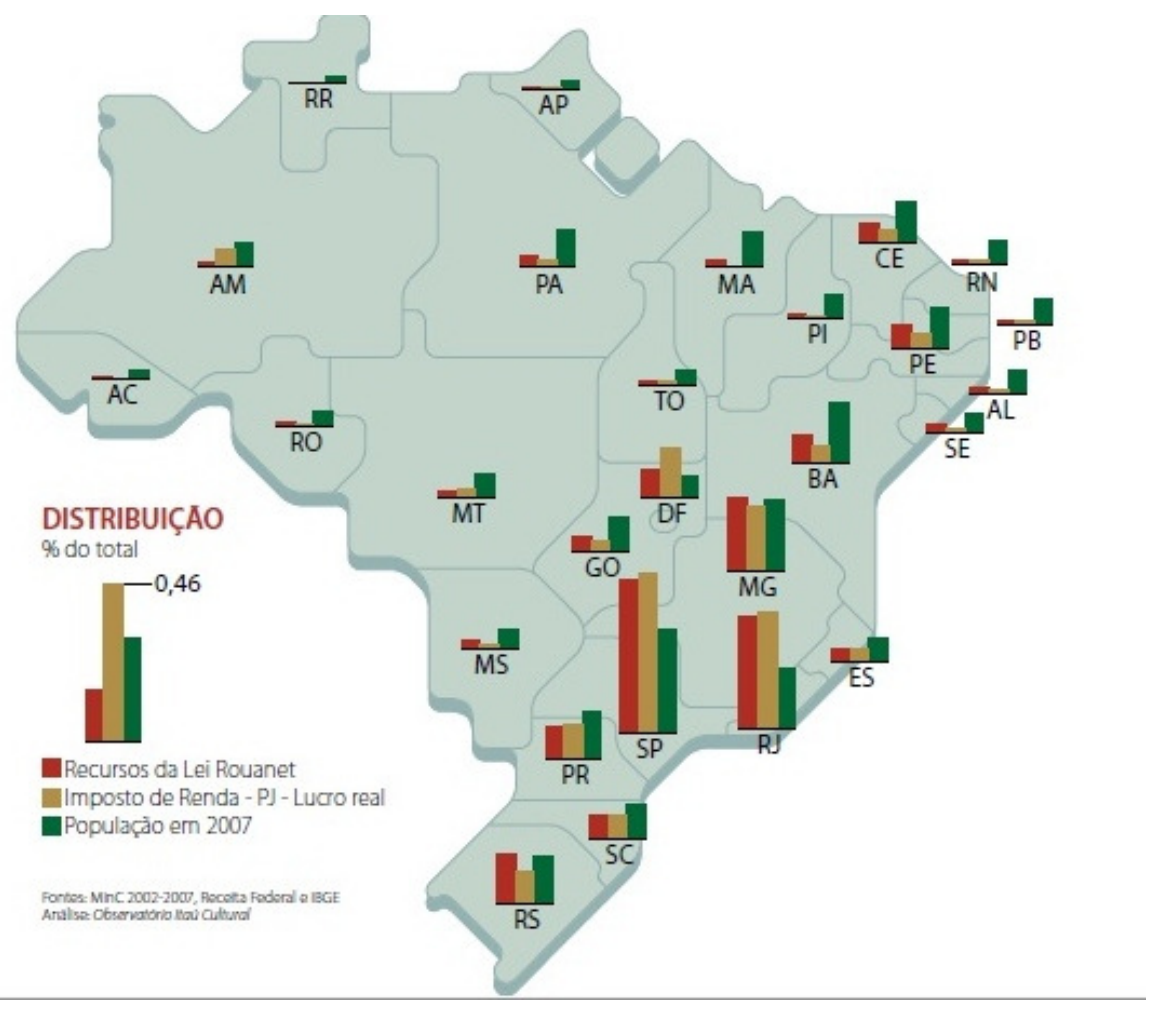

\footnotetext{
${ }^{218}$ AGUIAR, Josélia. Concentração Geográfica, Entre a Realidade e o Mito. In: Revista Observatório Itaú Cultural. № 7 (jan./mar. 2009). São Paulo: Itaú Cultural, 2009. P. 17 e 19.
} 
Tabela no 1:

\begin{tabular}{|c|c|c|c|c|c|c|c|c|c|c|}
\hline \multirow[b]{2}{*}{ UF } & \multirow[b]{2}{*}{$\begin{array}{l}\text { Rouanet } \\
2002 \\
\text { a } 2007\end{array}$} & \multirow[b]{2}{*}{$\begin{array}{l}\text { IFPJ } \\
\text { (Lucro } \\
\text { real) }\end{array}$} & \multicolumn{3}{|l|}{ IBGE } & \multirow{2}{*}{$\begin{array}{l}\text { DATASUS } \\
\text { Gosto } \\
\text { público } \\
2006 \text {-SUS }\end{array}$} & \multicolumn{4}{|c|}{ DADOS LEI ROUANET 2002-07 } \\
\hline & & & $\begin{array}{l}\text { PIB } \\
2005\end{array}$ & $\begin{array}{l}\text { Pop } \\
\text { total }\end{array}$ & $\begin{array}{l}\text { Pop } \\
200 \text { mil }\end{array}$ & & $\begin{array}{l}\text { Mecenato } \\
\text { (art. 18०) } \\
\text { \$ captado }\end{array}$ & $\begin{array}{l}\text { Mecenato } \\
\text { (art. 260) } \\
\text { Scaptado }\end{array}$ & $\begin{array}{l}\text { Mecensto } \\
\text { (art. 18*+26) } \\
\text { S captado }\end{array}$ & $\begin{array}{l}\text { FNC- } \\
\text { \$ captado }\end{array}$ \\
\hline$A C$ & $0 \%$ & $0 \%$ & $0 \%$ & $0 \%$ & $0 \%$ & $1 \%$ & $0 \%$ & $0 \%$ & $0 \%$ & $0 \%$ \\
\hline $\mathrm{AL}$ & $0 \%$ & $0 \%$ & $1 \%$ & $2 \%$ & $1 \%$ & $1 \%$ & $0 \%$ & $0 \%$ & $0 \%$ & $0 \%$ \\
\hline AP & $0 \%$ & $0 \%$ & $0 \%$ & $0 \%$ & $0 \%$ & $0 \%$ & $0 \%$ & $0 \%$ & $0 \%$ & $9 \%$ \\
\hline $\mathrm{AM}$ & $0 \%$ & $1 \%$ & $2 \%$ & $2 \%$ & $2 \%$ & $2 \%$ & $0 \%$ & $0 \%$ & $0 \%$ & $0 \%$ \\
\hline$B A$ & $2 \%$ & $1 \%$ & $4 \%$ & $8 \%$ & 696 & $6 \%$ & $1 \%$ & $6 \%$ & $2 \%$ & $8 \%$ \\
\hline$C E$ & $1 \%$ & $1 \%$ & $2 \%$ & 496 & $4 \%$ & $3 \%$ & $1 \%$ & $1 \%$ & $1 \%$ & $1 \%$ \\
\hline DF & $2 \%$ & $6 \%$ & $4 \%$ & $1 \%$ & $3 \%$ & $2 \%$ & 296 & $2 \%$ & $2 \%$ & $3 \%$ \\
\hline ES & $1 \%$ & $1 \%$ & $2 \%$ & $2 \%$ & $2 \%$ & $2 \%$ & $1 \%$ & $0 \%$ & $1 \%$ & $0 \%$ \\
\hline $\mathrm{GO}$ & $1 \%$ & $0 \%$ & $2 \%$ & $3 \%$ & $3 \%$ & $2 \%$ & $1 \%$ & $1 \%$ & $1 \%$ & $7 \%$ \\
\hline MA & $0 \%$ & $0 \%$ & $1 \%$ & $3 \%$ & $1 \%$ & $2 \%$ & $0 \%$ & $0 \%$ & $0 \%$ & $0 \%$ \\
\hline MT & $0 \%$ & $0 \%$ & $2 \%$ & $2 \%$ & $1 \%$ & $2 \%$ & $0 \%$ & $0 \%$ & $0 \%$ & $0 \%$ \\
\hline MS & $0 \%$ & $0 \%$ & $1 \%$ & $1 \%$ & 196 & $1 \%$ & $0 \%$ & $0 \%$ & $0 \%$ & $0 \%$ \\
\hline MG & $11 \%$ & $9 \%$ & $9 \%$ & $10 \%$ & $8 \%$ & $9 \%$ & $12 \%$ & $7 \%$ & $11 \%$ & $5 \%$ \\
\hline PA & $1 \%$ & $0 \%$ & $2 \%$ & $4 \%$ & $3 \%$ & $3 \%$ & $0 \%$ & $0 \%$ & $0 \%$ & $0 \%$ \\
\hline PB & $0 \%$ & $0 \%$ & $1 \%$ & 296 & $1 \%$ & $2 \%$ & $0 \%$ & $0 \%$ & $0 \%$ & $0 \%$ \\
\hline PR & $3 \%$ & $3 \%$ & $6 \%$ & $6 \%$ & $5 \%$ & $5 \%$ & $3 \%$ & $1 \%$ & $2 \%$ & $2 \%$ \\
\hline $\mathrm{PE}$ & $2 \%$ & $1 \%$ & $2 \%$ & $5 \%$ & $4 \%$ & $4 \%$ & $2 \%$ & $1 \%$ & $2 \%$ & $7 \%$ \\
\hline $\mathrm{PI}$ & $0 \%$ & $0 \%$ & $1 \%$ & $2 \%$ & $1 \%$ & $1 \%$ & $0 \%$ & $0 \%$ & $0 \%$ & $0 \%$ \\
\hline RJ & $26 \%$ & $26 \%$ & $12 \%$ & $8 \%$ & $14 \%$ & $10 \%$ & $25 \%$ & $24 \%$ & $25 \%$ & $26 \%$ \\
\hline $\mathrm{RN}$ & $0 \%$ & $0 \%$ & $1 \%$ & $2 \%$ & $1 \%$ & $2 \%$ & $0 \%$ & $0 \%$ & $0 \%$ & $0 \%$ \\
\hline RS & $6 \%$ & $3 \%$ & $7 \%$ & $6 \%$ & $5 \%$ & $6 \%$ & $6 \%$ & $9 \%$ & $7 \%$ & $4 \%$ \\
\hline RO & $0 \%$ & $0 \%$ & $1 \%$ & $1 \%$ & $0 \%$ & $1 \%$ & $0 \%$ & $0 \%$ & $0 \%$ & $2 \%$ \\
\hline RR & $0 \%$ & $0 \%$ & $0 \%$ & $0 \%$ & $0 \%$ & $0 \%$ & $0 \%$ & $0 \%$ & $0 \%$ & $1 \%$ \\
\hline $5 \mathrm{C}$ & $2 \%$ & $2 \%$ & $4 \%$ & $3 \%$ & $1 \%$ & $3 \%$ & $2 \%$ & $1 \%$ & $2 \%$ & $4 \%$ \\
\hline SP & $42 \%$ & $46 \%$ & $34 \%$ & $22 \%$ & $30 \%$ & $27 \%$ & $42 \%$ & $45 \%$ & $43 \%$ & $20 \%$ \\
\hline$S E$ & $0 \%$ & $0 \%$ & $1 \%$ & $1 \%$ & $1 \%$ & $1 \%$ & $0 \%$ & $0 \%$ & $0 \%$ & $0 \%$ \\
\hline TO & $0 \%$ & $0 \%$ & $0 \%$ & $1 \%$ & $0 \%$ & $1 \%$ & $0 \%$ & $0 \%$ & $0 \%$ & $0 \%$ \\
\hline
\end{tabular}

Em 2011, o quadro não foi alterado: até outubro, enquanto na Região Sudeste havia 1.271 projetos com captação de recursos, na Região Norte havia 91; na Região Nordeste, 184; na Região Norte, 15; e na Região Sul, 423. Dos valores captados, 79,13\% pertenciam à Região Sudeste; 0,49\% à Região Norte; 5,65\% à Região Nordeste, 3,95\% à Região Centro-Oeste e 10,78 à Região Sul. ${ }^{219}$ Salta aos olhos, mais uma vez, a concentração dos recursos na Região Sudeste, que, por sua vez, detém o maior número de empresas tributadas com base no lucro real no país, o que acaba sendo, segundo Josélia Aguiar, "compatível com a fonte de recursos". 220

\footnotetext{
${ }^{219}$ Dados obtidos em <http://sistemas.cultura.gov.br/salicnet/Salicnet/Salicnet.php>. Acesso em 24 out. 2011.

${ }^{220}$ AGUIAR, Josélia. Op. Cit. P. 16.
} 
Mais dados podem ser acrescentados ao quadro: cerca de $50 \%$ dos recursos incentivados são captados por $3 \%$ dos proponentes, onde se destacam empresas estatais como a Petrobrás, a Eletrobrás e o Banco do Brasil; de cada $\mathrm{R} \$ 10,00$ captados, apenas $\mathrm{R} \$ 1,00$ é dinheiro privado, enquanto os outros $\mathrm{R} \$ 9,00$ são de renúncia fiscal. Segundo o Ministério da Cultura, o modelo vigente possibilita uma baixa percepção acerca da aplicação de recursos públicos; demanda um alto custo operacional, sendo que nem sempre os projetos conseguem captar recursos; é insuficiente para abranger a diversidade das demandas da sociedade brasileira para a produção cultural; e não possibilita democratização do acesso aos bens e produtos culturais pela sociedade brasileira e do dinheiro público por artistas e produtores culturais. ${ }^{221}$

Em entrevista dada à Revista Observatório Itaú Cultural, ao ser questionado sobre a concentração regional, o ex-ministro Juca Ferreira é realista ao expor que:

"As regiões tem densidades demográficas diferentes e graus de desenvolvimento cultural diferentes, o que faz com que algumas regiões tenham mais proponentes $e$ outras menos. Mas, mesmo com essas considerações, a concentração ainda é excessiva. Por um motivo óbvio: as empresas querem retorno de imagem, e quem pode dar isso são artistas consagrados, a maioria deles estabelecida no Rio e em São Paulo, e as estruturas culturais dessa região. É preciso compreender que o dinheiro público não pode fortalecer desigualdades e concentrações, mas contribuir para uma distribuição mais justa." 222

A seguir, ele exemplifica a situação descrita acima:

"Projetos no interior do Piauí, de Pernambuco, do Maranhão não despertam interesses das empresas. Citei o interior do Piauí porque lá tem um dos traços mais antigos de presença do ser humano nas Américas. Lá está sendo constituído um parque, na serra da Capivara, que é irretocável do ponto de vista do mérito científico e um dos melhores parques arqueológicos do mundo. Pois ninguém quer investir lá. Um diretor de marketing de uma empresa me disse: "Juca, você quer que eu enterre dinheiro no interior do Piauí?". Eu compreendo o que ele está me dizendo. Posso não concordar, mas não posso obrigar que a empresa invista lá. A preocupação do ministério é que todas as áreas da cultura de todas as regiões do Brasil e de todas as classes sociais tenham atendimento da Lei Rouanet. Mas quando a empresa pinça o projeto em que

\footnotetext{
${ }^{221}$ V. MINISTÉRIO DA CULTURA. Nova Lei de Fomento à Cultura. Brasília: Ministério da Cultura, 2009.

Disponível em

<http://blogs.cultura.gov.br/blogdarouanet/files/2009/03/novaleidefomentoacultura.pdf $>$. Acesso em 30 out. 2011.

${ }^{222}$ FERREIRA, Juca. Entrevista. In: Revista Observatório Itaú Cultural. № 7 (jan./mar. 2009). São Paulo: Itaú Cultural, 2009. P. 35.
} 
vai investir ela faz uma remodelagem da política e acaba aprovando $80 \%$ dos projetos no Rio e em São Paulo, principalmente projetos voltados para a classe média e de alta renda, que são consumidoras. Por isso, não se trata de mais rigor ou menos rigor. Não é um problema individual de cada projeto, mas do modelo. (...) O mecanismo da Lei Rouanet faz com que a empresa privada tenha a decisão final, e ela não tem um crivo público, o que leva à distorção. " 223

Diante deste quadro distorcido ocasionado pelo atual modelo da Lei Rouanet, o Ministério da Cultura, com a finalidade de democratizar o financiamento cultural e o acesso aos bens e aos produtos culturais pelos brasileiros, elaborou, em conjunto com a sociedade civil, um anteprojeto de lei que institui o Programa Nacional de Fomento e Incentivo à Cultura - Procultura. A discussão pela reformulação da Lei Rouanet, iniciada na gestão Gilberto Gil e evidenciada por seu sucessor, Juca Ferreira, tornou-se o Projeto de Lei no 6.722/2010, atualmente em trâmite na Câmara dos Deputados.

Em linhas gerais, o Projeto de Lei no 6.722/2010 propõe as seguintes mudanças: a criação de critérios específicos para incentivar a criação, a democratização do acesso e da economia da cultura (quanto mais orientado às políticas públicas e à democratização do acesso, maior será a renúncia fiscal, que variará entre $30 \%, 70 \%$, $80 \%, 90 \%$ e $100 \%$ ), sendo que os segmentos culturais detentores de uma alta pontuação de acordo com uma escala a ser definida pelo Ministério da Cultura poderão receber $100 \%$ de renúncia fiscal; a possibilidade de empresas que realizarem editais serem beneficiadas com maior renúncia fiscal; a criação de um sistema nacional de informações e incentivos; o aumento do percentual de renúncia fiscal para pessoa física para 10\%; "vitaminar" o Fundo Nacional de Cultura, que deverá ser acompanhado por fundos setoriais específicos como o Fundo Nacional das Artes, do Patrimônio, do Livro e Leitura; bem como a criação de atrativos para patrocinadores que incluem a criação de um ranking das empresas que mais investem no ramo cultural, o aumento de visibilidade da participação privada e a criação do Selo de Responsabilidade

\footnotetext{
${ }^{223}$ Ibid. P. 35.
} 
Cultural. $^{224}$ Entretanto, a Receita Federal não autorizou a extensão da renúncia fiscal para as empresas tributadas sobre o lucro presumido, o que acaba limitando o investimento privado. Deveria ser levado em consideração, conforme o gráfico na página 101, que a maior parte das empresas tributadas sobre o lucro real estão localizadas em São Paulo, contribuindo, assim, para a concentração regional da aplicação dos recursos.

À guisa de conclusão, deve ser sublinhado que no âmbito desta discussão, o Poder Público deverá levar em consideração que a democratização cultural não deve ser compreendida como um movimento de cima para baixo, isto é, ser detentora de uma função de difundir uma "alta" cultura em detrimento de uma "baixa" cultura. Em outras palavras, a imposição de uma cultura dita erudita sobre uma cultura dita popular. Ressalta-se que sempre deverá ser respeitado o princípio constitucional da diversidade cultural, estudado no primeiro capítulo, corroborado aqui pela pesquisadora Isaura Botelho:

"Apesar dos novos aportes ao debate sobre as desigualdades de acesso da população à vida cultural, a difusão da cultura erudita permanece - em todo mundo - a prioridade orçamentária dos poderes públicos. O fundamental para reverter esse quadro, pareceme, será a reformulação de políticas onde os poderes públicos coloquem à disposição os meios para que cada indivíduo tenha uma vida cultural ativa, permitindo-Ihe desenvolver sua capacidade de processar as diversas linguagens e expressões artísticas, mais do que simplesmente lhe dar acesso material ao que tem mais prestígio num determinado quadro de valores estéticos. Falamos, portanto, da formação global do indivíduo, do investimento em sua criatividade, o que vai incidir diretamente em sua qualidade de vida e em sua capacidade de dar voz à suas necessidades. É esta formação integral do indivíduo que pode constituir o alicerce de uma verdadeira cidadania cultural." 225

\footnotetext{
${ }^{224}$ Cf. GRUMAN, Marcelo. Incentivos fiscais para as artes: um balanço histórico e perspectivas futuras. Disponível em <http://www.culturaemercado.com.br/wpcontent/uploads/2011/05/ROUANET_FINAL21.pdf>. Acesso em 31 out. 2011.

${ }^{225}$ BOTELHO, Isaura. Democratização cultural: Desdobramentos de uma ideia. Disponível em <http://www.blogacesso.com.br/?p=66>. Acesso em 30 out. 2011.
} 


\section{Conclusão.}

"A cultura não é um fim em si mesma e não pode ser usada como refúgio para egoísmos ou covardias pessoais." 226

A partir da definição do termo "cultura" para o Direito e de suas características como um direito humano e fundamental, o presente trabalho buscou, ao longo de suas páginas, traçar um panorama sobre as políticas públicas culturais brasileiras desde os anos 1930 e os principais meios legais para sua efetivação, tutela e democratização. Sendo um direito fundamental, status conferido pela Constituição Federal de 1988, a cultura possui assento no primordial princípio da dignidade da pessoa humana. No entanto, o painel atual demonstra tristes constatações.

Desde a criação do incentivo fiscal à cultura nos anos 1980, que ainda hoje representa $80 \%$ do que é aplicado no setor, contra os $20 \%$ oriundos de recursos orçamentários, há uma tendência tanto pelo Poder Público quanto pela Sociedade Civil em tratar a cultura, conforme colocado por Leonardo Brant, como "se fosse apenas uma mercadoria, restringindo sua importância ao mínimo denominador neoliberal, transformando-se em mero commodity." ${ }^{227}$ Sendo um direito fundamental, a cultura não deve estar limitada a esta visão puramente mercantilista, onde é considerada como um "bom negócio" dirigido às elites brasileiras. Cabe ao Poder Público e à Sociedade Civil tratá-la como um fator de desenvolvimento social e humano, de modo a conferir-lhe uma visão ampla. Efetivar o direito fundamental à cultura é, sobretudo, um exercício de cidadania, democracia, de preservação da identidade nacional brasileira e de igualdade. Da mesma maneira, a cultura é um fator de desenvolvimento econômico ao país. Entretanto, não devemos ficar adstritos a este escopo limitado. Aqui não é defendida uma posição no sentido de que o incentivo fiscal deve ser extinto;

\footnotetext{
${ }^{226}$ SARAMAGO, José. José Saramago nas suas palavras. Lisboa: Ed. Caminho, 2010. P. 480.

227 BRANT, Leonardo. Diversidade Cultural e Desenvolvimento Social. In: BRANT, Leonardo (org.). Políticas Culturais, Vol. 1. Barueri: Ed. Manole, 2003. P. 3.
} 
ele apenas não pode ser o principal meio de financiamento à produção cultural brasileira, devendo ser somente readequado.

Pela plena efetivação do direito fundamental à cultura, algumas posturas devem ser adotadas não só pelo Poder Público, mas também pela sociedade. Os direitos culturais não devem ser mais vistos como os "parentes pobres" dos direitos humanos. Infelizmente, a cultura ainda é reconhecida como um ornamento do ser humano, enquanto, na verdade, é o seu substrato. Talvez este seja um dos motivos pelos quais haja uma escassa bibliografia sobre o tema, principalmente na área do Direito.

Conforme visto no primeiro capítulo, por ser um direito social, isto é, um direito humano de segunda geração, a cultura requer um maior protagonismo do Estado para sua efetivação. Isto é expresso na Constituição Federal de 1988 quando, ao tratar especificamente da cultura em seus artigos 215 e 216, determinou tarefas a serem cumpridas pelo Estado através de normas programáticas de eficácia limitada. Por via da elaboração de políticas públicas culturais pelo Estado em conjunto com a Sociedade Civil, que, por seu turno, tomam forma de normas jurídicas, são instituídos instrumentos para a efetivação do direito fundamental à cultura. Porém, mesmo com o uso de instrumentos de democracia participativa na administração pública, uma prática renovada durante o governo Lula, a participação da sociedade ainda é pequena. Políticas públicas culturais, como quaisquer outras políticas públicas, jamais devem ser elaboradas somente dentro de um gabinete fechado. É cabível a seguinte provocação: se nem mesmo parte da elite brasileira participa ativamente da elaboração de políticas públicas culturais, que é um interesse público, como o quadro deve ser alterado?

É preciso mudar a mentalidade, portanto. A cultura, sendo um direito fundamental, assim como a saúde, o meio ambiente, a liberdade, a educação, etc. não deve ser vista como apenas a cereja de um bolo. Devemos torná-la parte de sua massa. Como reflexo desta postura, o tema é pouco judicializado. A cultura, sendo um bem jurídico subjetivo, pode e deverá ser objeto de pleito perante os três poderes. Ressaltase a importância da Ação Civil Pública, que é o instrumento hábil para a implementação 
e cumprimento de políticas públicas, e a essencial atuação do Ministério Público para efetivação dos direitos fundamentais.

Sendo o Brasil um país de tradições democráticas recentes, falta à sociedade brasileira maturidade acerca da importância dos seus direitos e os meios pelos quais eles podem ser efetivados. Neste diapasão encontra-se o Tombamento, que é um dos principais instrumentos de preservação do patrimônio cultural brasileiro. $\mathrm{O}$ ato de tombar não deve ser mais considerado um ônus pelos proprietários de bens imóveis privados. O bem imóvel tombado deverá ter como finalidade a provocação de um diálogo constante entre o passado e o presente, o velho e o novo, preservando-se, assim, a memória local, regional e/ou nacional. Nas palavras empregadas por Mário de Andrade, "defender o nosso patrimônio histórico e artístico é alfabetização."

O Poder Público também deve cumprir seu papel. Como foi visto no terceiro capítulo, importantes ações foram realizadas durante as gestões Gilberto Gil/Juca Ferreira de modo a apresentar uma evolução no tratamento e na visibilidade da cultura pelo Governo Federal. Um dos principais passos a serem dados é a aprovação da PEC no 150/2003 pelo Congresso Nacional, que, ao aumentar os recursos destinados à cultura, possibilitará ao Ministério da Cultura não mais ocupar um papel marginal na seara dos ministérios. Outro passo a ser dado é a Administração Pública não permitir abusos do uso do dinheiro público por patrocinadores quando da utilização dos mecanismos de incentivo fiscal. Isto acaba sendo um atentado contra a democracia e aos direitos fundamentais, visto que o "Direito Constitucional Cultural compete tanto ao Estado como às associações e corporações privadas". ${ }^{228}$ Podemos citar como exemplo o caso de um espetáculo beneficiado pela Lei Rouanet encenado pelo grupo canadense Cirque du Soleil que, em 2006, teve liberada pelo Ministério da Cultura a captação de cerca de $R \$ 7$ milhões e cobrou pelo ingresso valores entre $R \$ 65,00$ e $R \$ 200,00$. Diante da realidade econômico-social brasileira, os valores cobrados foram incompatíveis para que um direito fundamental fosse gozado.

\footnotetext{
${ }^{228}$ SILVA, Vasco Pereira da. Op. Cit. P. 128.
} 
A aprovação do Plano Nacional de Cultura em dezembro de 2010, 48 anos após a elaboração do primeiro Plano Nacional de Educação, também foi um importantíssimo passo. Trata-se de uma lei que estará em constante debate e revisão até 2020, devendo ser aqui ressaltado que a participação da sociedade é imprescindível para seu sucesso. Contribuições por meio de seminários, congressos, audiências públicas e pelo site do Ministério da Cultura serão enriquecedoras e fundamentais.

Foi possível perceber no decorrer do presente trabalho, uma singela contribuição aos estudos culturais no âmbito jurídico, que o diagnóstico acerca da efetivação desta classe de direitos previstos na Constituição Federal de 1988 ainda não é satisfatório. Rudolf von Ihering preconizou que "a luta é a própria essência do direito." 229 Desta forma, termino esta monografia convocando o leitor para que lute para que o direito fundamental à cultura ocupe, ante sua negligenciada importância, uma posição central em todas as esferas do governo e da sociedade.

Nas palavras de Milton Nascimento e Fernando Brant,

"Eu briguei, apanhei, eu sofri, aprendi,

Eu cantei, eu berrei, eu chorei, eu sorri,

Eu saí pra sonhar meu país

E foi tão bom, não estava sozinho

A praça era alegria sadia

O povo era senhor

E só uma voz, numa só canção.

E foi por ter posto a mão no futuro

Que no presente preciso ser duro

E eu não posso me acomodar

Quero um país melhor." 230

229 IHERING, Rudolf Von. A luta pelo direito. Trad. João de Vasconcelos. 16a ed. Rio de Janeiro: Ed. Forense, 1998. P. 4.

${ }_{230}$ BRANT, Fernando; NASCIMENTO, Milton. Carta à República. Disponível em <http://www.miltonnascimento.com.br>. Acesso em 30 out. 2011. 


\section{Bibliografia}

AGUIAR, Josélia. Concentração Geográfica, Entre a Realidade e o Mito. In: Revista Observatório Itaú Cultural. № 7 (jan./mar. 2009). São Paulo: Itaú Cultural, 2009.

ANDRADE, Mario de. Anteprojeto para a criação do Serviço do Patrimônio Artístico Nacional. In: BATISTA, Marta Rossetti (org.). Revista do Patrimônio Histórico e Artístico Nacional, no 30. Brasília: Instituto do Patrimônio Histórico e Artístico Nacional - IPHAN, 2002.

BARBOSA DA SILVA, Frederico A. Economia e Política Cultural: acesso, emprego e financiamento. Brasília: Ministério da Cultura, 2007.

BARROSO, Luís Roberto. Eficácia e efetividade do direito à liberdade. In: Temas de Direito Constitucional. Rio de Janeiro: Ed. Renovar, 2001.

. O direito constitucional e a efetividade de suas normas - limites e possibilidades da Constituição brasileira. 9a edição. Rio de Janeiro: Renovar, 2009.

BENVENUTO LIMA JR., Jayme. Os Direitos Econômicos, Sociais e Culturais. Rio de Janeiro: Ed. Renovar, 2001.

BINENBJOM, GUSTAVO. Monismo e Dualismo no Brasil: uma dicotomia afinal irrelevante. In: Revista Forense, vol. 350. Rio de Janeiro: Editora Forense, 2000.

BOBBIO, Noberto. A Era dos Direitos. 19a Ed.. Rio de Janeiro: Elsevier, 1992.

BONAVIDES, Paulo. Curso de Direito Constitucional, 7ạ Ed. São Paulo: Ed. Malheiros, 1997. 
BOTELHO, Isaura. A política cultural e o plano das ideias. P. 16. Disponível em $<$ http://www.cult.ufba.br/enecult2007/IsauraBotelho.pdf>. Acesso em 20 out. 2011.

. Democratização cultural: Desdobramentos de uma ideia. Disponível em <http://www.blogacesso.com.br/?p=66>. Acesso em 30 out. 2011.

BRASIL. Constituição Federal de 1988. Disponível em <http://www.planalto.gov.br/ccivil_03/constituicao/constitui\%C3\%A7ao.htm>. . Minuta Consulta Pública - II Relatório Sobre o Cumprimento do PIDESC. Disponível em <http://www.dhescbrasil.org> Acesso em 09 set.2011.

BRASIL, Fabíola Bezerra de Castro Alves. O Fundo Nacional da Cultura como instrumento público de financiamento cultural. In: Políticas Culturais em Revista. Vol. 3. N.o2. Salvador: Ed. UFBA, 2010. P. 152. Disponível em <http://www.politicasculturaisemrevista.ufba.br>. Acesso em 28 set. 2011.

BRANT, Fernando; NASCIMENTO, Milton. Carta à República. Disponível em <http://www.miltonnascimento.com.br>. Acesso em 30 out. 2011.

BRANT, Leonardo. Diversidade Cultural e Desenvolvimento Social. In: BRANT, Leonardo (org.). Políticas Culturais, Vol. 1. Barueri: Ed. Manole, 2003.

CAENEGEM, R.C. van. "Iluminismo, Direito Natural e os Códigos Modernos: da Metade do Século XVIII ao Início do Século XIX." In: Uma Introdução Histórica ao Direito Privado. São Paulo: Martins Fontes, 1995. P. 117-118 apud BENVENUTO LIMA JR., Jayme. Os Direitos Econômicos, Sociais e Culturais. Rio de Janeiro: Ed. Renovar, 2001.

CALABRE, Lia. Políticas Culturais no Brasil: dos anos 1930 ao século XXI. Rio de Janeiro: Ed. FGV, 2009. 
. Política cultural no Brasil: um breve histórico. In CALABRE, Lia. Políticas culturais: diálogo indispensável. Rio de Janeiro: Edições Casa de Rui Barbosa, 2005.

CANÇADO TRINDADE, Antônio Augusto. Tratado de Direito Internacional dos Direitos Humanos, vol. 1. 2a Edição. Porto Alegre: Sergio Antonio Fabris Editor, 1997.

CANOTILHO, José Joaquim Gomes; MOREIRA, Vital. Constituição da República Portuguesa Anotada. 2a . Ed. 1ㅇvol. Coimbra: Ed. Coimbra, 1984.

CASTRO, Carlos Ribeiro Siqueira. A Constituição Aberta e os direitos fundamentais: ensaios sobre o constitucionalismo pós-moderno e comunitário. Rio de Janeiro: Ed. Forense, 2003.

CASTRO, Sonia Rabello de. O Estado na Preservação de Bens Culturais. Rio de Janeiro: Ed. Renovar, 1991.

CESNIK, Fábio de Sá. Guia do Incentivo à Cultura. 2a Edição. São Paulo, Ed. Manole, 2007.

CHAUÍ, Marilena. Cidadania Cultural. São Paulo: Editora Fundação Perseu Abramo, 2006. . Cultura \& Democracia. 9a ed.. São Paulo: Ed. Cortez, 2001.

COELHO, Teixeira. Dicionário Crítico de Política Cultural. 3ạ Ed. São Paulo: Ed. lluminuras, 2004. 
- O novo Papel dos Direitos Culturais - Entrevista com Farida Shaheed, da ONU. In: Observatório Itaú Cultural/OIC n. 11. (jan./abr. 2011). São Paulo: Itaú Cultural, 2011.

CUNHA FILHO, Francisco Humberto. Cultura e Democracia na Constituição Federal de 1988. A Representação de interesses e sua aplicação ao programa nacional de Apoio à Cultura. Rio de Janeiro: Letra Legal, 2004.

. Direitos Culturais como Direitos Fundamentais no

Ordenamento Jurídico Brasileiro. Brasília: Brasília Jurídica, 2000.

. Direitos Culturais no Brasil In: Revista Observatório do Itaú cultural, no 11. São Paulo: Itaú Cultural,2011.

DASSIN, Joan. Política e Cultura em Mário de Andrade. São Paulo: Ed. Duas Cidades, 1978.

FALCÃO, Joaquim Arruda. Política Cultural e Democracia: A preservação do Patrimônio Histórico e Artístico Nacional. In: MICELI, Sérgio (org.). Estado e Cultura no Brasil. São Paulo: Ed. Difel, 1984.

FARIA Ernesto. Dicionário Escolar Latino-Português. 4ạ Ed.. Rio de Janeiro: Ministério da Educação e Cultura, 1967.

FEIJÓ, Martin Cezar. O que é Política Cultural. 4ạ Edição. Coleção Primeiros Passos. São Paulo: Ed. Brasiliense, 1989.

FERREIRA, Juca. Entrevista. In: Revista Observatório Itaú Cultural. № 7 (jan./mar. 2009). São Paulo: Itaú Cultural, 2009. 
FREIRE JÚNIOR, Américo Bedê. O controle judicial de políticas públicas. São Paulo: Ed. Revista dos Tribunais, 2005.

GIL, Gilberto. Discurso de posse do Ministro da Cultura proferido em 02/01/2003. Disponível em <http://www1.folha.uol.com.br/folha/brasil/ult96u44344.shtml>. Acesso em 20 out. 2011.

GRUMAN, Marcelo. Incentivos fiscais para as artes: um balanço histórico e perspectivas futuras. Disponível em <http://www.culturaemercado.com.br/wpcontent/uploads/2011/05/ROUANET_FINAL21.pdf>. Acesso em 31 out. 2011.

HUNT, Lynn. A Invenção dos Direitos Humanos: uma história. Trad. Rosaura Eischenberg. São Paulo: Companhia das Letras, 2009.

IANNI, Octavio. O Estado e a Organização da Cultura. In: Encontros com a Civilização Brasileira. №1. Rio de Janeiro: Ed. Civilização Brasileira, 1978.

IHERING, Rudolf Von. A luta pelo direito. Trad. João de Vasconcelos. 16ạ ed. Rio de Janeiro: Ed. Forense, 1998.

Instituto do Patrimônio Histórico e Artístico Nacional - IPHAN. Inventário Nacional de Referências Culturais. Disponível em <http://www.iphan.gov.br>. Acesso em 07 out. 2011.

LARAIA, Roque de Barros. Cultura: Um Conceito Antropológico. 18a Ed.. Rio de Janeiro: Jorge Zahar Ed., 2005. 
LONDRES, Cecília. A Invenção do Patrimônio e a Memória Nacional. In: BOMENY, Helena (org.). Constelação Capanema: Intelectuais e Políticas. Rio de Janeiro: Ed. FGV, 2001.

MANCUSO, Rodolfo de Camargo. Ação Civil Pública: em defesa do meio ambiente, do patrimônio cultural e dos consumidores. São Paulo: Ed. Revista dos Tribunais, 2007.

MARSON, Melina Izar. Cinema e Políticas de Estado: da Embrafilme à Ancine. São Paulo: Escrituras Editora, 2009.

MARTINS, Vinicius. Fundamentos da atividade cinematográfica e audiovisual: teoria e prática. Rio de Janeiro: Ed. Elsevier, 2009.

MICELI, Sérgio. O Processo de "Construção Institucional" na área da cultura federal (anos 70). In: MICELI, Sérgio (org.). Estado e Cultura no Brasil. São Paulo: Ed.Difel, 1984.

MINISTÉRIO DA CULTURA. Apresentação de Projetos Culturais. Disponível em <http://www.cultura.gov.br>. Acesso em 08 set. 2011.

- Nova Lei de Fomento à Cultura. Brasília: Ministério da Cultura, 2009. Disponível em <http://blogs.cultura.gov.br/blogdarouanet/files/2009/03/novaleidefomentoacultura.p df>. Acesso em 30 out. 2011.

Plano Nacional de Cultura. Disponível em <http://www.cultura.gov.br/site/2011/05/27/plano-nacional-de-cultura-22/> . Plano Nacional de Cultura: Diretrizes Gerais. 2aㅡ Ed. Brasília: Ministério da Cultura, 2008. 
Ponto de Cultura. Disponível em <http://www.cultura.gov.br/culturaviva/ponto-de-cultura/>. Acesso em 20 out. 2011.

MIRANDA, Alcides da Rocha. Entrevista. In: BATISTA, Marta Rossetti (org.). Revista do Patrimônio Histórico e Artístico Nacional, no 30. Brasília: Instituto do Patrimônio Histórico e Artístico Nacional - IPHAN, 2002.

MIRANDA, Jorge. Manual de Direito Constitucional. Tomo IV. Coimbra: Ed. Coimbra. Tomo IV, 1988.

NOGUEIRA, Ruy Barbosa. Curso de direito tributário. 11ạ. Ed. São Paulo: Ed. Saraiva, 1993.

OLIVIERI, Cristiane Garcia. Cultura Neoliberal: leis de incentivo como política pública de cultura. São Paulo: Escrituras Editora, 2004.

PEDRO, Jesús Prieto de. Direitos Culturais, O Filho Pródigo dos Direitos Humanos In: Observatório Itaú Cultural/OIC n. 11. (jan./abr. 2011). São Paulo: Itaú Cultural, 2011.

PIEROTH; SCHLINK. Grundrechte - S. III, p. 15 apud SILVA, Vasco Pereira da. A Cultura que eu tenho direito: Direitos Fundamentais e Cultura. Lisboa: Ed. Almadina, 2007.

PIOVESAN, Flávia. Direitos Humanos e o Direito Constitucional Internacional. 8a . Edição. São Paulo: Ed. Saraiva 2007.

PORTELLA, Sérgio Luiz Dias. Patrimônio antropofágico: AM reflete MA. In: CALABRE, Lia. Políticas culturais: diálogo indispensável. Rio de Janeiro: Edições Casa de Rui Barbosa, 2005. 
REIS, Ana Paula Félix. O Processo de Elaboração da Política Nacional de Cultura na Gestão do Ministro Gil. Disponível em <http://www.cult.ufba.br/enecult2008/14381.pdf>. Acesso em 21 out. 2011.

RODRIGUES, Geisa de Assis. Ação Popular. In: DIDDIER JR., Fredie (org.). Ações Constitucionais. 4ạ. Ed.. Salvador: Ed. Forum, 2009.

RODRIGUES, Marcelo Abelha. Ação Civil Pública. In: DIDDIER JR., Fredie (org.). Ações Constitucionais. 4a . Ed.. Salvador: Ed. Forum, 2009.

ROUSSEAU, Jean Jacques. O Contrato Social. Coleção Os Pensadores, vol. 1.. Trad. Lourdes Santos Machado. São Paulo: Ed. Nova Cultural, 1999.

RUBIM, Antonio Albino Canelas. Políticas Culturais no Brasil: Itinerários e atualidade. In: BOLAÑo, César et al. (org.). Economia da Arte e da Cultura. São Paulo: Itaú Cultural, 2010.

SARAMAGO, José. José Saramago nas suas palavras. Lisboa: Ed. Caminho, 2010.

SARLET, Ingo Wolfgang. A Eficácia dos Direitos Fundamentais. Porto Alegre: Editora do Advogado, 1998. - Dignidade da pessoa humana e direitos fundamentais na Constituição Federal de 1988. 4ạ. Ed. Porto Alegre: Livraria do Advogado, 2006

SILVA, Frederico A. Barbosa; ARAÚJO, Herton Ellery (org.). Cultura Viva: avaliação do programa arte educação e cidadania. Brasília: Ipea, 2010. 
SILVA, José Afonso da. Aplicabilidade das Normas Constitucionais. 4ạ Ed. São Paulo: Ed. Malheiros, 2000.

. Curso de Direito Constitucional Positivo. 34ạ Ed. São Paulo: Ed.

Malheiros, 2011.

- Ordenação Constitucional da Cultura. São Paulo: Editora

Malheiros. 2001.

SILVA, Vasco Pereira da. A Cultura que eu tenho direito: Direitos Fundamentais $e$ Cultura. Lisboa: Ed. Almadina, 2007.

SOARES, Inês Virgínia Prado. Direito ao (do) Patrimônio Cultural Brasileiro. Belo Horizonte: Ed. Fórum, 2009.

SOTO, Cecília et al.. Políticas públicas de cultura: os mecanismos de participação social. In: RUBIM, Antonio Albino Canelas (Org). Políticas Culturais no Governo Lula. Salvador: UFBA, 2010.

SOUZA FILHO, Carlos Frederico Marés de. Bens Culturais e sua Proteção Jurídica. 3a Ed.. Curitiba: Ed. Juruá, 2009.

TORRES, Ricardo Lobo. Curso de Direito Financeiro e Tributário. 17a Ed. Rio de Janeiro: Ed. Renovar, 2010.

STF. ADIN no 1.950/SP. Rel. Min. Eros Grau, Brasília, 03 novembro 2005. . Ag. Reg. No A.I. no 674764/PI. Rel. Min. Dias Toffoli. Brasília, 04 outubro 2011. 
. Ag. Reg. No A.I. no 734.487/PR. Rel. Min. Ellen Gracie. Brasília, 03 agosto 2010.

TJRJ. A.I. n.o 2008.002.35098. Rel. Des. Helena Gaede. Rio de Janeiro. 05. Novembro 2008.

TYLOR, Edward. Primitive Culture. Lenders, John Murray \& Co. [1958, Nova York, Harper Torchbooks] apud LARAIA, Roque de Barros. Cultura: Um Conceito Antropológico. 18 a. Ed.. Rio de Janeiro: Jorge Zahar Ed., 2005.

VILAÇA, Marcos Vinícios. Cultura e Estado. Brasília: Ministério da Educação e Cultura, 1985.

WERNECK SODRÉ, Nelson. A Luta Pela Cultura. Rio de Janeiro: Editora Bertrand Brasil, 1990.

ZÉ, Tom. Multiplicar-se única. Disponível em <http://www.tomze.com.br>. Acesso em 12 set. 2011. 


\title{
7. Anexos.
}

\author{
ANEXO I \\ LEI № 8.313, DE 23 DE DEZEMBRO DE 1991. \\ Restabelece princípios da Lei $n^{\circ} 7.505$, de \\ 2 de julho de 1986, institui o Programa \\ Nacional de Apoio à Cultura (Pronac) e dá \\ outras providências.
}

O PRESIDENTE DA REPÚBLICA Faço saber que o Congresso Nacional decreta e eu sanciono a seguinte lei:

\section{CAPÍTULO I}

Disposições Preliminares

Art. $1^{\circ}$ Fica instituído o Programa Nacional de Apoio à Cultura (Pronac), com a finalidade de captar e canalizar recursos para o setor de modo a:

I - contribuir para facilitar, a todos, os meios para o livre acesso às fontes da cultura e o pleno exercício dos direitos culturais;

II - promover e estimular a regionalização da produção cultural e artística brasileira, com valorização de recursos humanos e conteúdos locais;

III - apoiar, valorizar e difundir o conjunto das manifestações culturais e seus respectivos criadores;

IV - proteger as expressões culturais dos grupos formadores da sociedade brasileira e responsáveis pelo pluralismo da cultura nacional;

V - salvaguardar a sobrevivência e o florescimento dos modos de criar, fazer e viver da sociedade brasileira; brasileiro;

$\mathrm{VI}$ - preservar os bens materiais e imateriais do patrimônio cultural e histórico

VII - desenvolver a consciência internacional e o respeito aos valores culturais de outros povos ou nações;

VIII - estimular a produção e difusão de bens culturais de valor universal, formadores e informadores de conhecimento, cultura e memória;

IX - priorizar o produto cultural originário do País. 
Art. $2^{\circ} \mathrm{O}$ Pronac será implementado através dos seguintes mecanismos:

I - Fundo Nacional da Cultura (FNC);

II - Fundos de Investimento Cultural e Artístico (Ficart);

III - Incentivo a projetos culturais.

$\S 1^{\circ}$ Os incentivos criados por esta Lei somente serão concedidos a projetos culturais cuja exibição, utilização e circulação dos bens culturais deles resultantes sejam abertas, sem distinção, a qualquer pessoa, se gratuitas, e a público pagante, se cobrado ingresso.

$\S 2^{\circ}$ É vedada a concessão de incentivo a obras, produtos, eventos ou outros decorrentes, destinados ou circunscritos a coleções particulares ou circuitos privados que estabeleçam limitações de acesso.

Art. $3^{\circ}$ Para cumprimento das finalidades expressas no art. $1^{\circ}$ desta lei, os projetos culturais em cujo favor serão captados e canalizados os recursos do Pronac atenderão, pelo menos, um dos seguintes objetivos:

I - incentivo à formação artística e cultural, mediante:

a) concessão de bolsas de estudo, pesquisa e trabalho, no Brasil ou no exterior, a autores, artistas e técnicos brasileiros ou estrangeiros residentes no Brasil;

b) concessão de prêmios a criadores, autores, artistas, técnicos e suas obras, filmes, espetáculos musicais e de artes cênicas em concursos e festivais realizados no Brasil;

c) instalação e manutenção de cursos de caráter cultural ou artístico, destinados à formação, especialização e aperfeiçoamento de pessoal da área da cultura, em estabelecimentos de ensino sem fins lucrativos;

II - fomento à produção cultural e artística, mediante:

a) produção de discos, vídeos, obras cinematográficas de curta e média metragem e filmes documentais, preservação do acervo cinematográfico bem assim de outras obras de reprodução videofonográfica de caráter cultural;

b) edição de obras relativas às ciências humanas, às letras e às artes;

c) realização de exposições, festivais de arte, espetáculos de artes cênicas, de música e de folclore;

d) cobertura de despesas com transporte e seguro de objetos de valor cultural destinados a exposições públicas no País e no exterior; 
e) realização de exposições, festivais de arte e espetáculos de artes cênicas ou congêneres;

III - preservação e difusão do patrimônio artístico, cultural e histórico, mediante:

a) construção, formação, organização, manutenção, ampliação e equipamento de museus, bibliotecas, arquivos e outras organizações culturais, bem como de suas coleções e acervos;

b) conservação e restauração de prédios, monumentos, logradouros, sítios e demais espaços, inclusive naturais, tombados pelos Poderes Públicos;

c) restauração de obras de artes e bens móveis e imóveis de reconhecido valor cultural;

d) proteção do folclore, do artesanato e das tradições populares nacionais;

IV - estímulo ao conhecimento dos bens e valores culturais, mediante: artísticos;

a) distribuição gratuita e pública de ingressos para espetáculos culturais e

b) levantamentos, estudos e pesquisas na área da cultura e da arte e de seus vários segmentos;

c) fornecimento de recursos para o FNC e para fundações culturais com fins específicos ou para museus, bibliotecas, arquivos ou outras entidades de caráter cultural;

V - apoio a outras atividades culturais e artísticas, mediante:

a) realização de missões culturais no país e no exterior, inclusive através do fornecimento de passagens;

b) contratação de serviços para elaboração de projetos culturais;

c) ações não previstas nos incisos anteriores e consideradas relevantes pelo Ministro de Estado da Cultura, consultada a Comissão Nacional de Apoio à Cultura.

\section{CAPÍTULO II \\ Do Fundo Nacional da Cultura (FNC)}

Art. $4^{\circ}$ Fica ratificado o Fundo de Promoção Cultural, criado pela Lei $n^{\circ} 7.505$, de 2 de julho de 1986, que passará a denominar-se Fundo Nacional da Cultura (FNC), com o objetivo de captar e destinar recursos para projetos culturais compatíveis com as finalidades do Pronac e de: 
I - estimular a distribuição regional eqüitativa dos recursos a serem aplicados na execução de projetos culturais e artísticos;

II - favorecer a visão interestadual, estimulando projetos que explorem propostas culturais conjuntas, de enfoque regional;

III - apoiar projetos dotados de conteúdo cultural que enfatizem o aperfeiçoamento profissional e artístico dos recursos humanos na área da cultura, a criatividade e a diversidade cultural brasileira;

IV - contribuir para a preservação e proteção do patrimônio cultural e histórico brasileiro;

V - favorecer projetos que atendam às necessidades da produção cultural e aos interesses da coletividade, aí considerados os níveis qualitativos e quantitativos de atendimentos às demandas culturais existentes, o caráter multiplicador dos projetos através de seus aspectos sócio-culturais e a priorização de projetos em áreas artísticas e culturais com menos possibilidade de desenvolvimento com recursos próprios.

§ 1으 O FNC será administrado pelo Ministério da Cultura e gerido por seu titular, para cumprimento do Programa de Trabalho Anual, segundo os princípios estabelecidos nos arts. $1^{\circ}$ e $3^{\circ}$.

$\S 2^{\circ}$ Os recursos do FNC somente serão aplicados em projetos culturais após aprovados, com parecer do órgão técnico competente, pelo Ministro de Estado da Cultura.

$\S 3^{\circ}$ Os projetos aprovados serão acompanhados e avaliados tecnicamente pelas entidades supervisionadas, cabendo a execução financeira à SEC/PR.

$\S 4^{\circ}$ Sempre que necessário, as entidades supervisionadas utilizarão peritos para análise e parecer sobre os projetos, permitida a indenização de despesas com o deslocamento, quando houver, e respectivos pró-labore e ajuda de custos, conforme ficar definido no regulamento.

$\S 5^{\circ}$ O Secretário da Cultura da Presidência da República designará a unidade da estrutura básica da SEC/PR que funcionará como secretaria executiva do FNC.

$\S 6^{\circ}$ Os recursos do FNC não poderão ser utilizados para despesas de manutenção administrativa do Ministério da Cultura, exceto para a aquisição ou locação de equipamentos e bens necessários ao cumprimento das finalidades do Fundo.

$\S 7^{\circ}$ Ao término do projeto, a SEC/PR efetuará uma avaliação final de forma a verificar a fiel aplicação dos recursos, observando as normas e procedimentos a serem definidos no regulamento desta lei, bem como a legislação em vigor.

$\S 8^{\circ}$ As instituições públicas ou privadas recebedoras de recursos do FNC e executoras de projetos culturais, cuja avaliação final não for aprovada pela SEC/PR, nos 
termos do parágrafo anterior, ficarão inabilitadas pelo prazo de três anos ao recebimento de novos recursos, ou enquanto a SEC/PR não proceder a reavaliação do parecer inicial.

Art. $5^{\circ}$ O FNC é um fundo de natureza contábil, com prazo indeterminado de duração, que funcionará sob as formas de apoio a fundo perdido ou de empréstimos reembolsáveis, conforme estabelecer o regulamento, e constituído dos seguintes recursos:

I - recursos do Tesouro Nacional;

II - doações, nos termos da legislação vigente;

III - legados;

IV - subvenções e auxílios de entidades de qualquer natureza, inclusive de organismos internacionais;

V - saldos não utilizados na execução dos projetos a que se referem o Capítulo IV e o presente capítulo desta lei;

VI - devolução de recursos de projetos previstos no Capítulo IV e no presente capítulo desta lei, e não iniciados ou interrompidos, com ou sem justa causa;

VII - um por cento da arrecadação dos Fundos de Investimentos Regionais, a que se refere a Lei $n^{\circ} 8.167$, de 16 de janeiro de 1991, obedecida na aplicação a respectiva origem geográfica regional;

VIII - Três por cento da arrecadação bruta dos concursos de prognósticos e loterias federais e similares cuja realização estiver sujeita a autorização federal, deduzindo-se este valor do montante destinados aos prêmios;

IX - reembolso das operações de empréstimo realizadas através do fundo, a título de financiamento reembolsável, observados critérios de remuneração que, no mínimo, lhes preserve o valor real;

$X$ - resultado das aplicações em títulos públicos federais, obedecida a legislação vigente sobre a matéria;

XI - conversão da dívida externa com entidades e órgãos estrangeiros, unicamente mediante doações, no limite a ser fixado pelo Ministro da Economia, Fazenda e Planejamento, observadas as normas e procedimentos do Banco Central do Brasil;

XII - saldos de exercícios anteriores; XIII recursos de outras fontes.

Art. $6^{\circ}$ O FNC financiará até oitenta por cento do custo total de cada projeto, mediante comprovação, por parte do proponente, ainda que pessoa jurídica de direito 
público, da circunstância de dispor do montante remanescente ou estar habilitado à obtenção do respectivo financiamento, através de outra fonte devidamente identificada, exceto quanto aos recursos com destinação especificada na origem.

\section{$\S 1^{\circ}$ (Vetado)}

$\S 2^{\circ}$ Poderão ser considerados, para efeito de totalização do valor restante, bens e serviços oferecidos pelo proponente para implementação do projeto, a serem devidamente avaliados pela SEC/PR.

Art. $7^{\circ}$ A SEC/PR estimulará, através do FNC, a composição, por parte de instituições financeiras, de carteiras para financiamento de projetos culturais, que levem em conta o caráter social da iniciativa, mediante critérios, normas, garantias e taxas de juros especiais a serem aprovados pelo Banco Central do Brasil.

\section{CAPÍTULO III}

Dos Fundos de Investimento Cultural e Artístico (Ficart)

Art. $8^{\circ}$ Fica autorizada a constituição de Fundos de Investimento Cultural e Artístico (Ficart), sob a forma de condomínio, sem personalidade jurídica, caracterizando comunhão de recursos destinados à aplicação em projetos culturais e artísticos.

Art. 9ำ São considerados projetos culturais e artísticos, para fins de aplicação de recursos do FICART, além de outros que venham a ser declarados pelo Ministério da Cultura:

I - a produção comercial de instrumentos musicais, bem como de discos, fitas, vídeos, filmes e outras formas de reprodução fonovideográficas;

II - a produção comercial de espetáculos teatrais, de dança, música, canto, circo e demais atividades congêneres;

III - a edição comercial de obras relativas às ciências, às letras e às artes, bem como de obras de referência e outras de cunho cultural;

IV - construção, restauração, reparação ou equipamento de salas e outros ambientes destinados a atividades com objetivos culturais, de propriedade de entidades com fins lucrativos;

$V$ - outras atividades comerciais ou industriais, de interesse cultural, assim consideradas pelo Ministério da Cultura.

Art. 10. Compete à Comissão de Valores Mobiliários, ouvida a SEC/PR, disciplinar a constituição, o funcionamento e a administração dos Ficart, observadas as disposições desta lei e as normas gerais aplicáveis aos fundos de investimento. 
Art. 11. As quotas dos Ficart, emitidas sempre sob a forma nominativa ou escritural, constituem valores mobiliários sujeitos ao regime da Lei $n^{\circ} 6.385$, de 7 de dezembro de 1976.

Art. 12. O titular das quotas de Ficart:

I - não poderá exercer qualquer direito real sobre os bens e direitos integrantes do patrimônio do fundo;

II - não responde pessoalmente por qualquer obrigação legal ou contratual, relativamente aos empreendimentos do fundo ou da instituição administradora, salvo quanto à obrigação de pagamento do valor integral das quotas subscritas.

Art. 13. A instituição administradora de Ficart compete:

I - representá-lo ativa e passivamente, judicial e extrajudicialmente;

II - responder pessoalmente pela evicção de direito, na eventualidade da liquidação deste.

Art. 14. Os rendimentos e ganhos de capital auferidos pelos Ficart ficam isentos do imposto sobre operações de crédito, câmbio e seguro, assim como do imposto sobre renda e proventos de qualquer natureza.

Art. 15. Os rendimentos e ganhos de capital distribuídos pelos Ficart, sob qualquer forma, sujeitam-se à incidência do imposto sobre a renda na fonte à alíquota de vinte e cinco por cento.

Parágrafo único. Ficam excluídos da incidência na fonte de que trata este artigo, os rendimentos distribuídos a beneficiário pessoas jurídica tributada com base no lucro real, os quais deverão ser computados na declaração anual de rendimentos.

Art. 16. Os ganhos de capital auferidos por pessoas físicas ou jurídicas não tributadas com base no lucro real, inclusive isentas, decorrentes da alienação ou resgate de quotas dos Ficart, sujeitam-se à incidência do imposto sobre a renda, à mesma alíquota prevista para a tributação de rendimentos obtidos na alienação ou resgate de quotas de fundos mútuos de ações.

$\S 1^{\circ}$ Considera-se ganho de capital a diferença positiva entre o valor de cessão ou resgate da quota e o custo médio atualizado da aplicação, observadas as datas de aplicação, resgate ou cessão, nos termos da legislação pertinente.

$\S 2^{\circ} \mathrm{O}$ ganho de capital será apurado em relação a cada resgate ou cessão, sendo permitida a compensação do prejuízo havido em uma operação com o lucro obtido em outra, da mesma ou diferente espécie, desde que de renda variável, dentro do mesmo exercício fiscal. 
$\S 3^{\circ} \mathrm{O}$ imposto será pago até o último dia útil da primeira quinzena do mês subseqüente àquele em que o ganho de capital foi auferido.

$\S 4^{\circ}$ Os rendimentos e ganhos de capital a que se referem o caput deste artigo e o artigo anterior, quando auferidos por investidores residentes ou domiciliados no exterior, sujeitam-se à tributação pelo imposto sobre a renda, nos termos da legislação aplicável a esta classe de contribuintes.

Art. 17. O tratamento fiscal previsto nos artigos precedentes somente incide sobre os rendimentos decorrentes de aplicações em Ficart que atendam a todos os requisitos previstos na presente lei e na respectiva regulamentação a ser baixada pela Comissão de Valores Mobiliários.

Parágrafo único. Os rendimentos e ganhos de capital auferidos por Ficart, que deixem de atender aos requisitos específicos desse tipo de fundo, sujeitar-se-ão à tributação prevista no artigo 43 da Lei $n^{\circ} 7.713$, de 22 de dezembro de 1988.

\section{CAPÍTULO IV}

\section{Do Incentivo a Projetos Culturais}

Art. 18. Com o objetivo de incentivar as atividades culturais, a União facultará às pessoas físicas ou jurídicas a opção pela aplicação de parcelas do Imposto sobre a Renda, a título de doações ou patrocínios, tanto no apoio direto a projetos culturais apresentados por pessoas físicas ou por pessoas jurídicas de natureza cultural, como através de contribuições ao FNC, nos termos do art. 50, inciso II, desta Lei, desde que os projetos atendam aos critérios estabelecidos no art. $1^{\circ}$ desta Lei.

$\S 1^{\circ}$ Os contribuintes poderão deduzir do imposto de renda devido as quantias efetivamente despendidas nos projetos elencados no $\S 3^{\circ}$, previamente aprovados pelo Ministério da Cultura, nos limites e nas condições estabelecidos na legislação do imposto de renda vigente, na forma de:

a) doações; e

b) patrocínios.

$\S 2^{\circ}$ As pessoas jurídicas tributadas com base no lucro real não poderão deduzir o valor da doação ou do patrocínio referido no parágrafo anterior como despesa operacional.

$\S 3^{\circ}$ As doações e os patrocínios na produção cultural, a que se refere o $\S 1^{\circ}$, atenderão exclusivamente aos seguintes segmentos:

a) artes cênicas;

b) livros de valor artístico, literário ou humanístico;

c) música erudita ou instrumental; 
d) exposições de artes visuais;

e) doações de acervos para bibliotecas públicas, museus, arquivos públicos e cinematecas, bem como treinamento de pessoal e aquisição de equipamentos para a manutenção desses acervos;

f) produção de obras cinematográficas e videofonográficas de curta e média metragem e preservação e difusão do acervo audiovisual; e

g) preservação do patrimônio cultural material e imaterial.

h) construção e manutenção de salas de cinema e teatro, que poderão funcionar também como centros culturais comunitários, em Municípios com menos de 100.000 (cem mil) habitantes.

Art. 19. Os projetos culturais previstos nesta Lei serão apresentados ao Ministério da Cultura, ou a quem este delegar atribuição, acompanhados do orçamento analítico, para aprovação de seu enquadramento nos objetivos do PRONAC.

$\S 1^{\circ} \mathrm{O}$ proponente será notificado dos motivos da decisão que não tenha aprovado o projeto, no prazo máximo de cinco dias.

$\S 2^{\circ}$ Da notificação a que se refere o parágrafo anterior, caberá pedido de reconsideração ao Ministro de Estado da Cultura, a ser decidido no prazo de sessenta dias.

\section{$\S 3^{\circ}$ (Vetado)}

$\S 4^{\circ}$ (Vetado)

\section{$\S 5^{\circ}$ (Vetado)}

$\S 6^{\circ} \mathrm{A}$ aprovação somente terá eficácia após publicação de ato oficial contendo o título do projeto aprovado e a instituição por ele responsável, o valor autorizado para obtenção de doação ou patrocínio e o prazo de validade da autorização.

$\S 7^{\circ} 0$ Ministério da Cultura publicará anualmente, até 28 de fevereiro, o montante dos recursos autorizados pelo Ministério da Fazenda para a renúncia fiscal no exercício anterior, devidamente discriminados por beneficiário.

§ 8ํ Para a aprovação dos projetos será observado o princípio da nãoconcentração por segmento e por beneficiário, a ser aferido pelo montante de recursos, pela quantidade de projetos, pela respectiva capacidade executiva e pela disponibilidade do valor absoluto anual de renúncia fiscal.

Art. 20. Os projetos aprovados na forma do artigo anterior serão, durante sua execução, acompanhados e avaliados pela SEC/PR ou por quem receber a delegação destas atribuições. 
$\S 1^{\circ} \mathrm{A} S \mathrm{SE} / \mathrm{PR}$, após o término da execução dos projetos previstos neste artigo, deverá, no prazo de seis meses, fazer uma avaliação final da aplicação correta dos recursos recebidos, podendo inabilitar seus responsáveis pelo prazo de até três anos.

$\S 2^{\circ}$ Da decisão a que se refere o parágrafo anterior, caberá pedido de reconsideração ao Ministro de Estado da Cultura, a ser decidido no prazo de sessenta dias.

$\S 3^{\circ} \mathrm{O}$ Tribunal de Contas da União incluirá em seu parecer prévio sobre as contas do Presidente da República análise relativa a avaliação de que trata este artigo.

Art. 21. As entidades incentivadoras e captadoras de que trata este Capítulo deverão comunicar, na forma que venha a ser estipulada pelo Ministério da Economia, Fazenda e Planejamento, e SEC/PR, os aportes financeiros realizados e recebidos, bem como as entidades captadoras efetuar a comprovação de sua aplicação.

Art. 22. Os projetos enquadrados nos objetivos desta lei não poderão ser objeto de apreciação subjetiva quanto ao seu valor artístico ou cultural.

Art. 23. Para os fins desta lei, considera-se:

I - (Vetado)

II - patrocínio: a transferência de numerário, com finalidade promocional ou a cobertura, pelo contribuinte do imposto sobre a renda e proventos de qualquer natureza, de gastos, ou a utilização de bem móvel ou imóvel do seu patrimônio, sem a transferência de domínio, para a realização, por outra pessoa física ou jurídica de atividade cultural com ou sem finalidade lucrativa prevista no art. $3^{\circ}$ desta lei.

$\S 1^{\circ}$ Constitui infração a esta Lei o recebimento pelo patrocinador, de qualquer vantagem financeira ou material em decorrência do patrocínio que efetuar.

$\S 2^{\circ}$ As transferências definidas neste artigo não estão sujeitas ao recolhimento do Imposto sobre a Renda na fonte.

Art. 24. Para os fins deste Capítulo, equiparam-se a doações, nos termos do regulamento:

I - distribuições gratuitas de ingressos para eventos de caráter artístico-cultural por pessoa jurídica a seus empregados e dependentes legais;

II - despesas efetuadas por pessoas físicas ou jurídicas com o objetivo de conservar, preservar ou restaurar bens de sua propriedade ou sob sua posse legítima, tombados pelo Governo Federal, desde que atendidas as seguintes disposições:

a) preliminar definição, pelo Instituto Brasileiro do Patrimônio Cultural - IBPC, das normas e critérios técnicos que deverão reger os projetos e orçamentos de que trata este inciso; 
b) aprovação prévia, pelo IBPC, dos projetos e respectivos orçamentos de execução das obras;

c) posterior certificação, pelo referido órgão, das despesas efetivamente realizadas e das circunstâncias de terem sido as obras executadas de acordo com os projetos aprovados.

Art. 25. Os projetos a serem apresentados por pessoas físicas ou pessoas jurídicas, de natureza cultural para fins de incentivo, objetivarão desenvolver as formas de expressão, os modos de criar e fazer, os processos de preservação e proteção do patrimônio cultural brasileiro, e os estudos e métodos de interpretação da realidade cultural, bem como contribuir para propiciar meios, à população em geral, que permitam o conhecimento dos bens de valores artísticos e culturais, compreendendo, entre outros, os seguintes segmentos: congêneres;

I - teatro, dança, circo, ópera, mímica e congêneres;

II - produção cinematográfica, videográfica, fotográfica, discográfica e

III - literatura, inclusive obras de referência;

IV - música; congêneres;

$\mathrm{V}$-artes plásticas, artes gráficas, gravuras, cartazes, filatelia e outras

$\mathrm{VI}$ - folclore e artesanato;

VII - patrimônio cultural, inclusive histórico, arquitetônico, arqueológico, bibliotecas, museus, arquivos e demais acervos;

VIII - humanidades; e

IX - rádio e televisão, educativas e culturais, de caráter não-comercial.

Parágrafo único. Os projetos culturais relacionados com os segmentos do inciso II deste artigo deverão beneficiar exclusivamente as produções independentes, bem como as produções culturais-educativas de caráter não comercial, realizadas por empresas de rádio e televisão.

Art. 26. O doador ou patrocinador poderá deduzir do imposto devido na declaração do Imposto sobre a Renda os valores efetivamente contribuídos em favor de projetos culturais aprovados de acordo com os dispositivos desta Lei, tendo como base os seguintes percentuais:

I - no caso das pessoas físicas, oitenta por cento das doações e sessenta por cento dos patrocínios; 
II - no caso das pessoas jurídicas tributadas com base no lucro real, quarenta por cento das doações e trinta por cento dos patrocínios.

$\S 1^{\circ}$ A pessoa jurídica tributada com base no lucro real poderá abater as doações e patrocínios como despesa operacional.

$\S 2^{\circ}$ O valor máximo das deduções de que trata o caput deste artigo será fixado anualmente pelo Presidente da República, com base em um percentual da renda tributável das pessoas físicas e do imposto devido por pessoas jurídicas tributadas com base no lucro real.

$\S 3^{\circ}$ Os benefícios de que trata este artigo não excluem ou reduzem outros benefícios, abatimentos e deduções em vigor, em especial as doações a entidades de utilidade pública efetuadas por pessoas físicas ou jurídicas.

$\S 4^{\circ}$ (Vetado)

$\S 5^{\circ}$ O Poder Executivo estabelecerá mecanismo de preservação do valor real das contribuições em favor de projetos culturais, relativamente a este Capítulo.

Art. 27. A doação ou o patrocínio não poderá ser efetuada a pessoa ou instituição vinculada ao agente.

$\S 1^{\circ}$ Consideram-se vinculados ao doador ou patrocinador:

a) a pessoa jurídica da qual o doador ou patrocinador seja titular, administrador, gerente, acionista ou sócio, na data da operação, ou nos doze meses anteriores;

b) o cônjuge, os parentes até o terceiro grau, inclusive os afins, e os dependentes do doador ou patrocinador ou dos titulares, administradores, acionistas ou sócios de pessoa jurídica vinculada ao doador ou patrocinador, nos termos da alínea anterior;

c) outra pessoa jurídica da qual o doador ou patrocinador seja sócio.

$\S 2^{-}$Não se consideram vinculadas as instituições culturais sem fins lucrativos, criadas pelo doador ou patrocinador, desde que devidamente constituídas e em funcionamento, na forma da legislação em vigor.

Art. 28. Nenhuma aplicação dos recursos previstos nesta Lei poderá ser feita através de qualquer tipo de intermediação.

Parágrafo único. A contratação de serviços necessários à elaboração de projetos para a obtenção de doação, patrocínio ou investimento, bem como a captação de recursos ou a sua execução por pessoa jurídica de natureza cultural, não configura a intermediação referida neste artigo. 
Art. 29. Os recursos provenientes de doações ou patrocínios deverão ser depositados e movimentados, em conta bancária específica, em nome do beneficiário, e a respectiva prestação de contas deverá ser feita nos termos do regulamento da presente Lei.

Parágrafo único. Não serão consideradas, para fins de comprovação do incentivo, as contribuições em relação às quais não se observe esta determinação.

Art. 30. As infrações aos dispositivos deste capítulo, sem prejuízo das sanções penais cabíveis, sujeitarão o doador ou patrocinador ao pagamento do valor atualizado do Imposto sobre a Renda devido em relação a cada exercício financeiro, além das penalidades e demais acréscimos previstos na legislação que rege a espécie.

$\S 1^{\circ}$ Para os efeitos deste artigo, considera-se solidariamente responsável por inadimplência ou irregularidade verificada a pessoa física ou jurídica propositora do projeto.

$\S 2^{\circ}$ A existência de pendências ou irregularidades na execução de projetos da proponente junto ao Ministério da Cultura suspenderá a análise ou concessão de novos incentivos, até a efetiva regularização.

$\S 3^{\text {o Sem }}$ prejuízo do parágrafo anterior, aplica-se, no que couber, cumulativamente, o disposto nos arts. 38 e seguintes desta Lei.

\section{CAPÍTULO V \\ DAS DISPOSIÇÕES GERAIS E TRANSITÓRIAS}

Art. 31. Com a finalidade de garantir a participação comunitária, a representação de artista e criadores no trato oficial dos assuntos da cultura e a organização nacional sistêmica da área, o Governo Federal estimulará a institucionalização de Conselhos de Cultura no Distrito Federal, nos Estados, e nos Municípios.

Art. 32. Fica instituída a Comissão Nacional de incentivo à Cultura - CNIC, com a seguinte composição:

I - o Secretário da Cultura da Presidência da República;

II - os Presidentes das entidades supervisionadas pela SEC/PR;

III - o Presidente da entidade nacional que congregar os Secretários de Cultura das Unidades Federadas;

IV - um representante do empresariado brasileiro;

$\mathrm{V}$ - seis representantes de entidades associativas dos setores culturais e artísticos de âmbito nacional. 
§ 1ํ A CNIC será presidida pela autoridade referida no inciso I deste artigo que, para fins de desempate terá o voto de qualidade.

$\S 2^{\circ}$ Os mandatos, a indicação e a escolha dos representantes a que se referem os incisos IV e V deste artigo, assim como a competência da CNIC, serão estipulados e definidos pelo regulamento desta Lei.

Art. 33. A SEC/PR, com a finalidade de estimular e valorizar a arte e a cultura, estabelecerá um sistema de premiação anual que reconheça as contribuições mais significativas para a área:

I- de artistas ou grupos de artistas brasileiros ou residentes no Brasil, pelo conjunto de sua obra ou por obras individuais;

II - de profissionais da área do patrimônio cultural;

III - de estudiosos e autores na interpretação crítica da cultura nacional, através de ensaios, estudos e pesquisas.

Art. 34. Fica instituída a Ordem do Mérito Cultural, cujo estatuto será aprovado por Decreto do Poder Executivo, sendo que as distinções serão concedidas pelo Presidente da República, em ato solene, a pessoas que, por sua atuação profissional ou como incentivadoras das artes e da cultura, mereçam reconhecimento.

Art. 35. Os recursos destinados ao então Fundo de Promoção Cultural, nos termos do art. $1^{\circ}$, § $6^{\circ}$, da Lei $n^{\circ} 7.505$, de 2 de julho de 1986 , serão recolhidos ao Tesouro Nacional para aplicação pelo FNC, observada a sua finalidade.

Art. 36. O Departamento da Receita Federal, do Ministério da Economia, Fazenda e Planejamento, no exercício de suas atribuições específicas, fiscalizará a efetiva execução desta Lei, no que se refere à aplicação de incentivos fiscais nela previstos.

Art. 37. O Poder Executivo a fim de atender o disposto no art. 26, § $2^{\circ}$, desta Lei, adequando-o às disposições da Lei de Diretrizes Orçamentárias, enviará, no prazo de 30 dias, Mensagem ao Congresso Nacional, estabelecendo o total da renúncia fiscal e correspondente cancelamento de despesas orçamentárias.

Art. 38. Na hipótese de dolo, fraude ou simulação, inclusive no caso de desvio de objeto, será aplicada, ao doador e ao beneficiário, multa correspondente a duas vezes o valor da vantagem recebida indevidamente.

Art. 39. Constitui crime, punível com a reclusão de dois a seis meses e multa de vinte por cento do valor do projeto, qualquer discriminação de natureza política que atente contra a liberdade de expressão, de atividade intelectual e artística, de consciência ou crença, no andamento dos projetos a que se refere esta Lei. 
Art. 40. Constitui crime, punível com reclusão de dois a seis meses e multa de vinte por cento do valor do projeto, obter redução do imposto de renda utilizando-se fraudulentamente de qualquer benefício desta Lei.

$\S 1^{\circ}$ No caso de pessoa jurídica respondem pelo crime o acionista controlador e os administradores que para ele tenham concorrido.

$\S 2^{\circ}$ Na mesma pena incorre aquele que, recebendo recursos, bens ou valores em função desta Lei, deixa de promover, sem justa causa, atividade cultural objeto do incentivo.

Art. 41. O Poder Executivo, no prazo de sessenta dias, Regulamentará a presente lei.

Art. 42. Esta lei entra em vigor na data de sua publicação.

Art. 43. Revogam-se as disposições em contrário.

Brasília, 23 de dezembro de 1991; 170 da Independência e $103^{\circ}$ da República.

FERNANDO COLLOR

Jarbas Passarinho 


\section{ANEXO II}

\section{DECRETO № 5.761, DE 27 DE ABRIL DE 2006.}

Regulamenta a Lei $\mathrm{n}^{\circ} 8.313$, de 23 de dezembro de 1991, estabelece sistemática de execução do Programa Nacional de Apoio à Cultura PRONAC e dá outras providências.

O PRESIDENTE DA REPÚBLICA, no uso das atribuições que the confere o art. 84, incisos IV e VI, alínea "a", da Constituição, e tendo em vista o disposto na Lei $n^{\circ} 8.313$, de 23 de dezembro de 1991, DECRETA:

\section{CAPÍTULO I}

\section{DAS DISPOSIÇÕES GERAIS}

Art. $1^{\circ}$ O Programa Nacional de Apoio à Cultura - PRONAC desenvolver-se-á mediante a realização de programas, projetos e ações culturais que concretizem os princípios da Constituição, em especial seus arts. 215 e 216, e que atendam às finalidades previstas no art. $1^{\circ}$ e a pelo menos um dos objetivos indicados no art. $3^{\circ}$ da Lei $n^{\circ} 8.313$, de 23 de dezembro de 1991.

Art. $2^{\circ} \mathrm{Na}$ execução do PRONAC, serão apoiados programas, projetos e ações culturais destinados às seguintes finalidades:

I - valorizar a cultura nacional, considerando suas várias matrizes e formas de expressão;

II - estimular a expressão cultural dos diferentes grupos e comunidades que compõem a sociedade brasileira;

III - viabilizar a expressão cultural de todas as regiões do País e sua difusão em escala nacional;

IV-promover a preservação e o uso sustentável do patrimônio cultural brasileiro em sua dimensão material e imaterial;

V - incentivar a ampliação do acesso da população à fruição e à produção dos bens culturais;

$\mathrm{VI}$ - fomentar atividades culturais afirmativas que busquem erradicar todas as formas de discriminação e preconceito;

VII - desenvolver atividades que fortaleçam e articulem as cadeias produtivas e os arranjos produtivos locais que formam a economia da cultura;

VIII - apoiar as atividades culturais de caráter inovador ou experimental; 
IX - impulsionar a preparação e o aperfeiçoamento de recursos humanos para a produção e a difusão cultural;

$\mathrm{X}$ - promover a difusão e a valorização das expressões culturais brasileiras no exterior, assim como o intercâmbio cultural com outros países;

XI-estimular ações com vistas a valorizar artistas, mestres de culturas tradicionais, técnicos e estudiosos da cultura brasileira;

XII - contribuir para a implementação do Plano Nacional de Cultura e das políticas de cultura do Governo Federal; e

XIII - apoiar atividades com outras finalidades compatíveis com os princípios constitucionais e os objetivos preconizados pela Lei $\mathrm{n}^{\circ} 8.313$, de 1991, assim consideradas pelo Ministro de Estado da Cultura.

Art. $3^{\circ}$ A execução do PRONAC deverá obedecer às normas, diretrizes e metas estabelecidas em seu plano anual, que deverá estar de acordo com plano plurianual e com a Lei de Diretrizes Orçamentárias.

Parágrafo único. O plano anual de que trata este artigo será elaborado pelo Ministério da Cultura, que o publicará até o dia 30 de novembro do ano anterior àquele em que vigorará, de acordo com o disposto na Lei $n^{\circ} 8.313$, de 1991, e neste Decreto, observadas as diretrizes e metas estabelecidas no Plano Nacional de Cultura.

Art. $4^{\circ}$ Para os efeitos deste Decreto, entende-se por:

I - proponente: as pessoas físicas e as pessoas jurídicas, públicas ou privadas, com atuação na área cultural, que proponham programas, projetos e ações culturais ao Ministério da Cultura;

II - beneficiário: o proponente de programa, projeto ou ação cultural favorecido pelo PRONAC;

III - incentivador: o contribuinte do Imposto sobre a Renda e Proventos de qualquer natureza, pessoa física ou jurídica, que efetua doação ou patrocínio em favor de programas, projetos e ações culturais aprovados pelo Ministério da Cultura, com vistas a incentivos fiscais, conforme estabelecido na Lei $\mathrm{n}^{\circ} 8.313$, de 1991;

IV - doação: a transferência definitiva e irreversível de numerário ou bens em favor de proponente, pessoa física ou jurídica sem fins lucrativos, cujo programa, projeto ou ação cultural tenha sido aprovado pelo Ministério da Cultura;

V - patrocínio: a transferência definitiva e irreversível de numerário ou serviços, com finalidade promocional, a cobertura de gastos ou a utilização de bens móveis ou imóveis do patrocinador, sem a transferência de domínio, para a realização de programa, projeto ou ação cultural que tenha sido aprovado pelo Ministério da Cultura; 
VI - pessoa jurídica de natureza cultural: pessoa jurídica, pública ou privada, com ou sem fins lucrativos, cujo ato constitutivo disponha expressamente sobre sua finalidade cultural; e

VII - produção cultural-educativa de caráter não comercial: aquela realizada por empresa de rádio e televisão pública ou estatal.

Art. $5^{\circ}$ O Ministério da Cultura poderá escolher, mediante processo público de seleção, os programas, projetos e ações culturais a serem financiados pelos mecanismos definidos no art. $2^{\circ}$ da Lei $n^{\circ} 8.313$, de 1991, podendo designar comitês técnicos para essa finalidade.

$\S 1^{\circ}$ O montante dos recursos destinados aos processos públicos de seleção e a sua respectiva distribuição serão definidos em portaria do Ministério da Cultura, que será publicada no Diário Oficial da União, observado o estabelecido no plano anual do PRONAC.

$\S 2^{\circ}$ As empresas patrocinadoras interessadas em aderir aos processos seletivos promovidos pelo Ministério da Cultura deverão informar, previamente, o volume de recursos que pretendem investir, bem como sua área de interesse, respeitados o montante e a distribuição dos recursos definidas pelo Ministério da Cultura.

$\S 3^{\circ}$ A promoção de processos públicos para seleção de projetos realizada, de forma independente, por empresas patrocinadoras deverá ser previamente informada ao Ministério da Cultura.

Art. $6^{\circ}$ Os procedimentos administrativos relativos à apresentação, recepção, seleção, análise, aprovação, acompanhamento, monitoramento, avaliação de resultados e emissão de laudo de avaliação final dos programas, projetos e ações culturais, no âmbito do PRONAC, serão definidos pelo Ministro de Estado da Cultura e publicados no Diário Oficial da União, observadas as disposições deste Decreto.

$\S 1^{\circ}$ Nos casos de programas, projetos ou ações culturais que tenham como objeto a preservação de bens culturais tombados ou registrados pelos poderes públicos, em âmbito federal, estadual ou municipal, além do cumprimento das normas a que se refere o caput, será obrigatória a apreciação pelo órgão responsável pelo respectivo tombamento ou registro, observada a legislação relativa ao patrimônio cultural.

$\S 2^{\circ}$ Os programas, projetos e ações apresentados com vistas à utilização de um dos mecanismos de implementação do PRONAC serão analisados tecnicamente no âmbito do Ministério da Cultura, pelos seus órgãos ou entidades vinculadas, de acordo com as suas respectivas competências.

$\S 3^{\circ} \mathrm{A}$ apreciação técnica de que trata o $\S 2^{\circ}$ deverá verificar, necessariamente, o atendimento das finalidades do PRONAC, a adequação dos custos propostos aos praticados no mercado, sem prejuízo dos demais aspectos exigidos pela legislação aplicável, vedada a apreciação subjetiva baseada em valores artísticos ou culturais. 
$\S 4^{\circ}$ A proposta com o parecer técnico será submetida, de acordo com a matéria a que esteja relacionada, à Comissão do Fundo Nacional da Cultura, criada pelo art. 14, ou à Comissão Nacional de Incentivo à Cultura, a que se refere o art. 38, que recomendará ao Ministro de Estado da Cultura a aprovação total, parcial ou a não aprovação do programa, projeto ou ação em questão.

$\S 5^{\circ}$ Da decisão referida no $\S 4^{\circ}$ caberá pedido de reconsideração dirigido ao Ministro de Estado da Cultura, no prazo de até dez dias contados da comunicação oficial ao proponente.

$\S 6^{\circ} \mathrm{O}$ pedido de reconsideração será apreciado pelo Ministro de Estado da Cultura em até sessenta dias contados da data de sua interposição, após manifestação do órgão responsável pela análise técnica e, se julgar oportuno, da Comissão competente.

Art. $7^{\circ}$ Os programas, projetos e ações culturais aprovados serão acompanhados e avaliados tecnicamente pelos órgãos competentes do Ministério da Cultura.

$\S 1^{\circ} \mathrm{O}$ Ministério da Cultura e suas entidades vinculadas poderão utilizar-se dos serviços profissionais de peritos, antes da aprovação, durante e ao final da execução dos programas, projetos e ações já aprovados, permitida a indenização de despesas com deslocamento e pagamento de pró-labore ou de ajuda de custo para vistorias, quando necessário.

$\S 2^{\circ} \mathrm{O}$ acompanhamento e a avaliação referidos neste artigo objetivam verificar a fiel aplicação dos recursos e dar-se-ão por meio de comparação entre os resultados esperados e atingidos, os objetivos previstos e alcançados, os custos estimados e os efetivamente realizados, além do aferimento da repercussão da iniciativa na sociedade, de forma a atender aos objetivos da Lei $n^{\circ} 8.313$, de 1991, bem como ao disposto neste Decreto e no plano anual do PRONAC.

$\S 3^{\circ} \mathrm{A}$ avaliação referida no $\S 2^{\circ}$ será ultimada pelo Ministério da Cultura, mediante expedição do laudo final de avaliação, devendo o beneficiário ser notificado da decisão ministerial resultante.

$\S 4^{\circ}$ Da decisão a que se refere o $\S 3^{\circ}$ caberá recurso ao Ministro de Estado da Cultura, no prazo de dez dias, contados da data em que o beneficiário tomou ciência da decisão ministerial e do correspondente laudo final de avaliação.

$\S 5^{\circ} \mathrm{O}$ recurso de que trata o $\S 4^{\circ}$ será apreciado pelo Ministro de Estado da Cultura em até sessenta dias contados da data de sua interposição, após a manifestação do órgão competente do Ministério.

$\S 6^{\circ}$ No caso de não aprovação da execução dos programas, projetos e ações de que trata o $\S 3^{\circ}$, será estabelecido o prazo estritamente necessário para a conclusão do objeto proposto. 
$\S 7^{\circ}$ Não concluído o programa, projeto ou ação no prazo estipulado, serão aplicadas pelo Ministério da Cultura as penalidades previstas na Lei $\mathrm{n}^{\circ} 8.313$, de 1991, e adotadas as demais medidas administrativas cabíveis.

Art. $8^{\circ}$ As atividades de acompanhamento e avaliação técnica de programas, projetos e ações culturais poderão ser delegadas aos Estados, Distrito Federal e Municípios, bem como a órgãos ou entidades da administração pública federal e dos demais entes federados, mediante instrumento jurídico que defina direitos e deveres mútuos.

Parágrafo único. A delegação prevista no caput, relativamente aos Estados, Distrito Federal e Municípios, dependerá da existência, no respectivo ente federado, de lei de incentivos fiscais ou de fundos específicos para a cultura, bem como de órgão colegiado com atribuição de análise de programas e projetos culturais em que a sociedade tenha representação ao menos paritária em relação ao Poder Público e no qual as diversas áreas culturais e artísticas estejam representadas.

Art. $9^{\circ} \mathrm{O}$ Ministério da Cultura deverá elaborar e publicar relatório anual de avaliação do PRONAC, relativo à avaliação dos programas, projetos e ações culturais referidos neste Decreto, enfatizando o cumprimento do disposto no plano anual do PRONAC.

Parágrafo único. O relatório de que trata este artigo integrará a tomada de contas anual do Ministério da Cultura, a ser encaminhada ao Tribunal de Contas da União.

\section{CAPÍTULO II}

\section{DO FUNDO NACIONAL DA CULTURA}

Art. 10. Os recursos do Fundo Nacional da Cultura poderão ser utilizados, observado o disposto no plano anual do PRONAC, da seguinte forma:

I - recursos não-reembolsáveis - para utilização em programas, projetos e ações culturais de pessoas jurídicas públicas ou privadas sem fins lucrativos;

II - financiamentos reembolsáveis - para programas, projetos e ações culturais de pessoas físicas ou de pessoas jurídicas privadas, com fins lucrativos, por meio de agentes financeiros credenciados pelo Ministério da Cultura;

III - concessão de bolsas de estudo, de pesquisa e de trabalho - para realização de cursos ou desenvolvimento de projetos, no Brasil ou no exterior;

IV - concessão de prêmios;

$\mathrm{V}$ - custeio de passagens e ajuda de custos para intercâmbio cultural, no Brasil ou no exterior; 
VI - transferência a Estados, Municípios e Distrito Federal para desenvolvimento de programas, projetos e ações culturais, mediante instrumento jurídico que defina direitos e deveres mútuos; e

VII - em outras situações definidas pelo Ministério da Cultura, enquadráveis nos arts. $1^{\circ}$ e $3^{\circ}$ da Lei $n^{\circ} 8.313$, de 1991.

$\S 1^{\circ} \mathrm{O}$ Ministro de Estado da Cultura expedirá as instruções normativas necessárias para definição das condições e procedimentos das concessões previstas neste artigo e respectivas prestações de contas.

$\S 2^{\circ}$ Para o financiamento reembolsável, o Ministério da Cultura definirá com os agentes financeiros credenciados a taxa de administração, os prazos de carência, os juros limites, as garantias exigidas e as formas de pagamento, que deverão ser aprovadas pelo Banco Central do Brasil, conforme disposto no art. $7^{\circ}$ da Lei $n^{\circ} 8.313$, de 1991.

$\S 3^{\circ}$ A taxa de administração a que se refere o $\S 2^{\circ}$ não poderá ser superior a três por cento dos recursos disponíveis para financiamento.

$\S 4^{\circ}$ Para o financiamento de que trata o $\S 2^{\circ}$, serão fixadas taxas de remuneração que, no mínimo, preservem o valor originalmente concedido, conforme o disposto no inciso IX do art. $5^{\circ}$ da Lei $\mathrm{n}^{\circ} 8.313$, de 1991.

$\S 5^{\circ}$ Os subsídios decorrentes de financiamentos realizados a taxas inferiores à taxa de captação dos recursos financeiros pelo Governo Federal devem ser registrados pelo Fundo Nacional da Cultura para constar na lei orçamentária e suas informações complementares.

$\S 6^{\circ} \mathrm{Na}$ operacionalização do financiamento reembolsável, o agente financeiro será qualquer instituição financeira, de caráter oficial, devidamente credenciada pelo Ministério da Cultura.

$\S 7^{\circ}$ Os subsídios concedidos em financiamentos reembolsáveis, devem ser apurados para compor o rol dos benefícios creditícios e financeiros que integram as informações complementares da Lei Orçamentária Anual.

Art. 11. A execução orçamentária, financeira e patrimonial do Fundo Nacional da Cultura, bem como a supervisão e coordenação das atividades administrativas necessárias ao seu funcionamento, serão exercidas em conformidade com o disposto nos $\S \S 1^{\circ}$ e $3^{\circ}$ do art. $4^{\circ}$ da Lei $n^{\circ} 8.313$, de 1991.

Art. 12. O percentual de financiamento do Fundo Nacional da Cultura, limitado a oitenta por cento do custo total de cada programa, projeto ou ação cultural, será aprovado pelo Ministério da Cultura, mediante proposta da Comissão do Fundo Nacional da Cultura. 
Parágrafo único. A contrapartida a ser obrigatoriamente oferecida pelo proponente, para fins de complementação do custo total do programa, projeto ou ação cultural deverá ser efetivada mediante aporte de numerário, bens ou serviços, ou comprovação de que está habilitado à obtenção do respectivo financiamento por meio de outra fonte devidamente identificada, vedada como contrapartida a utilização do mecanismo de incentivos fiscais previstos.

Art. 13. A contrapartida será dispensada sempre que os recursos tenham sido depositados no Fundo Nacional da Cultura com destinação especificada na origem, tais como:

I-transferência de recursos a programas, projetos e ações culturais identificados pelo doador ou patrocinador por ocasião do depósito ao Fundo Nacional da Cultura, desde que correspondam ao custo total do projeto; e

II - programas, projetos e ações identificados pelo autor de emendas aditivas ao orçamento do Fundo Nacional da Cultura, ainda que o beneficiário seja órgão federal, desde que o valor da emenda corresponda ao custo total do projeto.

$\S 1^{\circ}$ Os programas, projetos e ações culturais previstos nos incisos I e II não serão objeto de apreciação pela Comissão do Fundo Nacional da Cultura.

$\S 2^{\circ}$ As entidades vinculadas ao Ministério da Cultura ficam dispensadas de apresentar contrapartida quando receberem recursos do Fundo Nacional da Cultura para o desenvolvimento de programas, projetos e ações culturais.

Art. 14. Fica criada, no âmbito do Ministério da Cultura, a Comissão do Fundo Nacional da Cultura, à qual compete:

I - avaliar e selecionar os programas, projetos e ações culturais que objetivem a utilização de recursos do Fundo Nacional da Cultura, de modo a subsidiar sua aprovação final pelo Ministro de Estado da Cultura;

II - apreciar as propostas de editais a serem instituídos em caso de processo público de seleção de programas, projetos e ações a serem financiados com recursos do Fundo Nacional da Cultura, para homologação pelo Ministro de Estado da Cultura;

III - elaborar a proposta de plano de trabalho anual do Fundo Nacional da Cultura, que integrará o plano anual do PRONAC, a ser submetida ao Ministro de Estado da Cultura para aprovação final de seus termos;

IV - apreciar as propostas de plano anual das entidades vinculadas ao Ministério da Cultura, com vistas à elaboração da proposta de que trata o inciso III; e

V - exercer outras atribuições estabelecidas pelo Ministro de Estado da Cultura.

Art. 15. A Comissão do Fundo Nacional da Cultura será integrada: 
I - pelo Secretário-Executivo do Ministério da Cultura, que a presidirá;

II - pelos titulares das Secretarias do Ministério da Cultura;

III - pelos presidentes das entidades vinculadas ao Ministério da Cultura; e

IV - por um representante do Gabinete do Ministro de Estado da Cultura.

Art. 16. A Comissão do Fundo Nacional da Cultura definirá em ato próprio, mediante proposta aprovada pela maioria absoluta de seus integrantes, as normas relativas à sua organização e funcionamento, que será homologado pelo Ministro de Estado da Cultura.

Art. 17. Os programas, projetos e ações culturais de iniciativa própria do Ministério da Cultura, a serem financiados com recursos do Fundo Nacional da Cultura, deverão constar de seu plano anual, obedecido o disposto no art. $3^{\circ}$, e serão apresentados à Comissão do Fundo Nacional da Cultura com orçamentos detalhados e justificativas referendadas, obrigatoriamente, pelo titular da unidade proponente ou seu substituto legal.

\section{CAPÍTULO III}

\section{DOS FUNDOS DE INVESTIMENTOS CULTURAIS E ARTÍSTICOS}

Art. 18. A Comissão de Valores Mobiliários - CVM disciplinará a constituição, o funcionamento e a administração dos Fundos de Investimentos Culturais e Artísticos FICART, nos termos do art. 10 da Lei $n^{\circ} 8.313$, de 1991.

$\S 1^{\circ}$ A CVM prestará informações ao Ministério da Cultura sobre a constituição dos FICART e seus respectivos agentes financeiros, inclusive quanto às suas áreas de atuação.

Art. 19. Para receber recursos dos FICART, os programas, projetos e ações culturais deverão destinar-se:

I - à produção e distribuição independentes de bens culturais e à realização de espetáculos artísticos e culturais :

II - à construção, restauração, reforma, equipamento e operação de espaços destinados a atividades culturais, de propriedade de entidades com fins lucrativos; e

III - a outras atividades comerciais e industriais de interesse cultural, assim consideradas pelo Ministério da Cultura.

Art. 20. A aplicação dos recursos dos FICART far-se-á, exclusivamente, por meio de:

I - contratação de pessoas jurídicas com sede no território brasileiro, tendo por finalidade exclusiva a execução de programas, projetos e ações culturais; 
II - participação em programas, projetos e ações culturais realizados por pessoas jurídicas de natureza cultural com sede no território brasileiro; e

III - aquisição de direitos patrimoniais para exploração comercial de obras literárias, audiovisuais, fonográficas e de artes cênicas, visuais, digitais e similares.

Art. 21. O Ministério da Cultura, em articulação com a CVM, definirá regras e procedimentos para acompanhamento e fiscalização da execução dos programas, projetos e ações culturais beneficiados com recursos do FICART.

\section{CAPÍTULO IV}

\section{DOS INCENTIVOS FISCAIS}

\section{Seção I}

\section{Das Formas de Aplicação}

Art. 22. A opção prevista no art. 24 da Lei $n^{\circ} 8.313$, de 1991, exercer-se-á:

I - em favor do próprio contribuinte do Imposto sobre a Renda e Proventos de qualquer natureza, quando proprietário ou titular de posse legítima de bens móveis e imóveis tombados pela União, e após cumprimento das exigências legais aplicáveis a bens tombados e mediante prévia apreciação pelo Instituto do Patrimônio Histórico e Artístico Nacional - IPHAN, no valor das despesas efetuadas com o objetivo de conservar ou restaurar aqueles bens; e

II - em favor de pessoas jurídicas contribuintes do Imposto sobre a Renda e Proventos de qualquer natureza, para compra de ingressos de espetáculos culturais e artísticos, desde que para distribuição gratuita comprovada a seus empregados e respectivos dependentes legais, obedecendo a critérios a serem definidos em ato do Ministério da Cultura.

Art. 23. As opções previstas nos arts. 18 e 26 da Lei $n^{\circ} 8.313$, de 1991, serão exercidas:

I - em favor do Fundo Nacional da Cultura, com destinação livre ou direcionada a programas, projetos e ações culturais específicos, sob a forma de doação, ou com destinação especificada pelo patrocinador, sob a forma de patrocínio;

II - em favor de programas, projetos e ações culturais apresentados por pessoas físicas ou jurídicas sem fins lucrativos, sob a forma de doação, abrangendo:

a) numerário ou bens, para realização de programas, projetos e ações culturais; e 
b) numerário para aquisição de produtos culturais e ingressos para espetáculos culturais e artísticos, de distribuição pública e gratuita, conforme normas a serem estabelecidas em ato do Ministério da Cultura;

III - em favor de programas, projetos e ações culturais apresentados por pessoas físicas ou jurídicas, com ou sem fins lucrativos, sob a forma de patrocínio, abrangendo:

a) numerário ou a utilização de bens, para realização de programas, projetos e ações culturais; e

b) numerário, para a cobertura de parte do valor unitário de produtos culturais e ingressos para espetáculos culturais e artísticos, conforme normas e critérios estabelecidos pelo Ministério da Cultura;

IV - em favor dos projetos culturais selecionados pelo Ministério da Cultura por meio de processo público de seleção, na forma estabelecida no art. $2^{\circ}$; e

$\mathrm{V}$ - em favor de projetos que tenham por objeto a valorização de artistas, mestres de culturas tradicionais, técnicos e estudiosos, com relevantes serviços prestados à cultura brasileira.

$\S 1^{\circ}$ Os programas, projetos e ações culturais apresentados por órgãos integrantes da administração pública direta somente poderão receber doação ou patrocínio na forma prevista no inciso I.

$\S 2^{\circ}$ É vedada a destinação de novo subsídio para a mesma atividade cultural em projeto já anteriormente subsidiado.

Art. 24. Equiparam-se a programas, projetos e ações culturais os planos anuais de atividades consideradas relevantes para a cultura nacional pela Comissão Nacional de Incentivo à Cultura:

I - de associações civis de natureza cultural, sem fins lucrativos, cuja finalidade estatutária principal seja dar apoio a instituições da União, dos Estados, do Distrito Federal ou dos Municípios, no atendimento dos objetivos previstos no art. $3^{\circ}$ da Lei $n^{\circ}$ 8.313, de 1991; e

II - de outras pessoas jurídicas de natureza cultural, sem fins lucrativos.

$\S 1^{\circ} \mathrm{O}$ valor a ser incentivado nos planos anuais será equivalente à estimativa de recursos a serem captados a título de doações e patrocínios, conforme constar da previsão anual de receita e despesa apresentada pelo proponente.

$\S 2^{\circ}$ Os planos anuais submeter-se-ão às mesmas regras de aprovação, execução, avaliação e prestação de contas aplicáveis aos programas, projetos e ações culturais incentivados. 
Art. 25. As despesas referentes aos serviços de captação dos recursos para execução de programas, projetos e ações culturais aprovados no âmbito da Lei $n^{\circ}$ 8.313, de 1991, serão detalhadas em planilha de custos, obedecidos os limites definidos em ato do Ministério da Cultura.

Parágrafo único. Os programas, projetos e ações culturais aprovados mediante a sistemática descrita no art. $5^{\circ}$ não poderão realizar despesas referentes a serviços de captação de recursos.

Art. 26. As despesas administrativas relacionadas aos programas, projetos e ações culturais que visem à utilização do mecanismo previsto neste Capítulo ficarão limitadas a quinze por cento do orçamento total do respectivo programa, projeto ou ação cultural.

Parágrafo único. Para efeito deste Decreto, entende-se por despesas administrativas aquelas executadas na atividade-meio dos programas, projetos e ações culturais, excluídos os gastos com pagamento de pessoal indispensável à execução das atividades-fim e seus respectivos encargos sociais, desde que previstas na planilha de custos.

Art. 27. Dos programas, projetos e ações realizados com recursos incentivados, total ou parcialmente, deverá constar formas para a democratização do acesso aos bens e serviços resultantes, com vistas a:

I - tornar os preços de comercialização de obras ou de ingressos mais acessíveis à população em geral;

II - proporcionar condições de acessibilidade a pessoas idosas, nos termos do art. 23 da Lei $n^{\circ} 10.741$, de $1^{\circ}$ de outubro de 2003, e portadoras de deficiência, conforme 0 disposto no art. 46 do Decreto ${ }^{0} 3.298$, de 20 de dezembro de 1999;

III - promover distribuição gratuita de obras ou de ingressos a beneficiários previamente identificados que atendam às condições estabelecidas pelo Ministério da Cultura; e

IV - desenvolver estratégias de difusão que ampliem o acesso.

Parágrafo único. O Ministério da Cultura poderá autorizar outras formas de ampliação do acesso para atender a finalidades não previstas nos incisos I a IV, desde que devidamente justificadas pelo proponente nos programas, projetos e ações culturais apresentados.

Art. 28. No caso de doação ou patrocínio de pessoas físicas e jurídicas em favor de programas e projetos culturais amparados pelo art. 18 da Lei $n^{\circ} 8.313$, de 1991, o percentual de dedução será de até cem por cento do valor do incentivo, respeitados os limites estabelecidos na legislação do imposto de renda vigente e o disposto no $\S 4^{\circ}$ do 
art. $3^{\circ}$ da Lei $n^{\circ} 9.249$, de 26 de dezembro de 1995 , não sendo permitida a utilização do referido montante como despesa operacional pela empresa incentivadora.

Art. 29. Os valores transferidos por pessoa física, a título de doação ou patrocínio, em favor de programas e projetos culturais enquadrados em um dos segmentos culturais previstos no art. 26 da Lei $n^{0} 8.313$, de 1991, poderão ser deduzidos do imposto devido, na declaração de rendimentos relativa ao período de apuração em que for efetuada a transferência de recursos, obedecidos os limites percentuais máximos de:

I - oitenta por cento do valor das doações; e

II - sessenta por cento do valor dos patrocínios.

Parágrafo único. O limite máximo das deduções de que tratam os incisos I e II é de seis por cento do imposto devido, nos termos do disposto no art. 22 da Lei $n^{\circ} 9.532$, de 10 de dezembro de 1997.

Art. 30. Observado o disposto no $\S 4^{\circ}$ do art. $3^{\circ}$ da Lei $n^{\circ} 9.249$, de 1995 , os valores correspondentes a doações e patrocínios realizados por pessoas jurídicas em favor de programas e projetos culturais enquadrados em um dos segmentos culturais previstos no art. 26 da Lei $n^{\circ} 8.313$, de 1991, poderão ser deduzidos do imposto devido, a cada período de apuração, nos limites percentuais máximos de:

I - quarenta por cento do valor das doações; e

II - trinta por cento do valor dos patrocínios.

$\S 1^{\circ}$ A pessoa jurídica tributada com base no lucro real poderá lançar em seus registros contábeis, como despesa operacional, o valor total das doações e dos patrocínios efetuados no período de apuração de seus tributos.

$\S 2^{\circ}$ O limite máximo das deduções de que tratam os incisos I e II do caput é de quatro por cento do imposto devido, nos termos do disposto no inciso II do art. $6^{\circ}$ da Lei $n^{\circ}$ 9.532, de 1997.

Art. 31. Não constitui vantagem financeira ou material a destinação ao patrocinador de até dez por cento dos produtos resultantes do programa, projeto ou ação cultural, com a finalidade de distribuição gratuita promocional, consoante plano de distribuição a ser apresentado quando da inscrição do programa, projeto ou ação, desde que previamente autorizado pelo Ministério da Cultura.

Parágrafo único. No caso de haver mais de um patrocinador, cada um poderá receber produtos resultantes do projeto em quantidade proporcional ao investimento efetuado, respeitado o limite de dez por cento para o conjunto de incentivadores. 
Art. 32. O valor da renúncia fiscal autorizado no âmbito do PRONAC e a correspondente execução orçamentário-financeira de programas, projetos e ações culturais deverão integrar o relatório anual de atividades.

Parágrafo único. O valor da renúncia de que trata o caput será registrado anualmente no demonstrativo de benefícios tributários da União para integrar as informações complementares à Lei Orçamentária Anual.

Art. 33. Os programas, projetos e ações culturais a serem analisados nos termos do inciso II do art. 25 da Lei $\mathrm{n}^{\circ}$ 8.313, de 1991, deverão beneficiar somente as produções culturais independentes.

Art. 34. As instituições culturais sem fins lucrativos referidas no $\S 2^{\circ}$ do art. 27 da Lei $n^{\circ} 8.313$, de 1991, poderão beneficiar-se de incentivos fiscais preferencialmente em seus planos anuais de atividades, nos termos do inciso II do art. 24 e seus $\S \S 1^{\circ}$ e $2^{\circ}$.

Parágrafo único. O Ministério da Cultura estabelecerá os critérios para avaliação das instituições referidas neste artigo.

Art. 35. A aprovação do projeto será publicada no Diário Oficial da União, contendo, no mínimo, os seguintes dados:

I - título do projeto;

II - número de registro no Ministério da Cultura;

III - nome do proponente e respectivo CNPJ ou CPF;

IV - extrato da proposta aprovada pelo Ministério da Cultura;

V - valor e prazo autorizados para captação dos recursos; e

VI - enquadramento quanto às disposições da Lei nº 8.313, de 1991.

$\S 1^{\circ}$ As instituições beneficiárias não poderão ressarcir-se de despesas efetuadas em data anterior à da publicação da portaria de autorização para captação de recursos.

$\S 2^{\circ}$ O prazo máximo para captação de recursos coincidirá com o término do exercício fiscal em que foi aprovado o projeto.

$\S 3^{\circ}$ No caso de nenhuma captação ou captação parcial dos recursos autorizados no prazo estabelecido, os programas, projetos e ações culturais poderão ser prorrogados, a pedido do proponente, nas condições e prazos estabelecidos no ato de prorrogação, de acordo com normas expedidas pelo Ministério da Cultura.

$\S 4^{\circ}$ Enquanto o Ministério da Cultura não se manifestar quanto ao pedido de prorrogação, fica o proponente impedido de promover a captação de recursos. 
Art. 36. As transferências financeiras dos incentivadores para os respectivos beneficiários serão efetuadas, direta e obrigatoriamente, em conta bancária específica, aberta em instituição financeira oficial, de abrangência nacional, credenciada pelo Ministério da Cultura.

Art. 37. O controle do fluxo financeiro entre os incentivadores e seus beneficiários estabelecer-se-á por meio do cruzamento das informações prestadas ao Ministério da Cultura, por parte de cada um deles, de modo independente.

\section{CAPÍTULO V}

\section{DA COMISSÃO NACIONAL DE INCENTIVO À CULTURA}

Art. 38. Compete à Comissão Nacional de Incentivo à Cultura, instituída pelo art. 32 da Lei $n^{\circ} 8.313$, de 1991:

I - subsidiar, mediante parecer técnico fundamentado do relator designado, nas decisões do Ministério da Cultura quanto aos incentivos fiscais e ao enquadramento dos programas, projetos e ações culturais nas finalidades e objetivos previstos na Lei $\mathrm{n}^{\circ}$ 8.313, de 1991, observado o plano anual do PRONAC;

II - subsidiar na definição dos segmentos culturais não previstos expressamente nos Capítulos III e IV da Lei $n^{\circ} 8.313$, de 1991;

III - analisar, por solicitação do seu presidente, as ações consideradas relevantes e não previstas no art. $3^{\circ}$ da Lei $n^{\circ} 8.313$, de 1991;

IV - fornecer subsídios para avaliação do PRONAC, propondo medidas para seu aperfeiçoamento;

V-emitir parecer sobre recursos apresentados contra decisões desfavoráveis à aprovação de programas e projetos culturais apresentados;

VI - emitir parecer sobre recursos contra decisões desfavoráveis quanto à avaliação e prestação de contas de programas, projetos e ações culturais realizados com recursos de incentivos fiscais;

VII - apresentar subsídios para a elaboração de plano de trabalho anual de incentivos fiscais, com vistas à aprovação do plano anual do PRONAC;

VIII - subsidiar na aprovação dos projetos de que trata o inciso V do art. 23; e

IX - exercer outras atribuições que Ihe forem conferidas pelo seu presidente.

$\S 1^{\circ} \mathrm{O}$ presidente da Comissão poderá deliberar ad referendum do colegiado, independentemente do oferecimento prévio dos subsídios a que se referem este artigo. 
$\S 2^{\circ}$ As deliberações da Comissão serão adotadas por maioria simples, cabendo ao seu presidente utilizar, além do seu voto, o de qualidade, para fins de desempate.

Art. 39. São membros da Comissão Nacional de Incentivo à Cultura:

I - o Ministro de Estado da Cultura, que a presidirá;

II - os presidentes de cada uma das entidades vinculadas ao Ministério da Cultura;

III - o presidente de entidade nacional que congrega os Secretários de Cultura das unidades federadas;

IV - um representante do empresariado nacional; e

$V$ - seis representantes de entidades associativas de setores culturais e artísticos, de âmbito nacional.

$\S 1^{\circ}$ Os membros referidos nos incisos I a III indicarão seus respectivos primeiro e segundo suplentes, que os substituirão em suas ausências e impedimentos legais e eventuais.

$\S 2^{\circ}$ Os membros e seus respectivos primeiro e segundo suplentes referidos nos incisos IV e $V$ terão mandato de dois anos, permitida uma única recondução, sendo o processo de sua indicação estabelecido em ato específico do Ministro de Estado da Cultura, obedecidos os critérios estabelecidos neste Decreto.

$\S 3^{\circ}$ A Comissão poderá constituir grupos técnicos com a finalidade de assessorála no exercício de suas competências.

$\S 4^{\circ} \mathrm{O}$ Ministério da Cultura prestará o apoio técnico e administrativo aos trabalhos da Comissão.

Art. 40. A indicação dos membros referidos no inciso $V$ do art. 39 deverá contemplar as seguintes áreas:

I - artes cênicas;

II - audiovisual;

III - música;

IV - artes visuais, arte digital e eletrônica;

V - patrimônio cultural material e imaterial, inclusive museológico e expressões das culturas negra, indígena, e das populações tradicionais; e

$\mathrm{VI}$ - humanidades, inclusive a literatura e obras de referência. 
Art. 41. Os membros da Comissão Nacional de Incentivo à Cultura e respectivos suplentes, referidos nos incisos IV e $\mathrm{V}$ do art. 39, ficam impedidos de participar da apreciação de programas, projetos e ações culturais nos quais:

I - tenham interesse direto ou indireto na matéria;

II - tenham participado como colaborador na elaboração do projeto ou tenham participado da instituição proponente nos últimos dois anos, ou se tais situações ocorrem quanto ao cônjuge, companheiro ou parente e afins até o terceiro grau; e

III - estejam litigando judicial ou administrativamente com o proponente ou respectivo cônjuge ou companheiro.

Parágrafo único. O membro da Comissão que incorrer em impedimento deve comunicar o fato ao referido colegiado, abstendo-se de atuar, sob pena de nulidade dos atos que praticar.

Art. 42. Os membros da Comissão Nacional de Incentivo à Cultura e respectivos suplentes, referidos nos inciso II do art. 39, abster-se-ão de atuar na apreciação de programas, projetos e ações culturais nos quais as respectivas entidades vinculadas tenham interesse direto na matéria, sob pena de nulidade dos atos que praticarem.

Art. 43. O funcionamento da Comissão Nacional de Incentivo à Cultura será regido por normas internas aprovadas pela maioria absoluta de seus membros, observado o disposto neste Decreto.

\section{CAPÍTULO VI}

\section{DA DIVULGAÇÃO DO PRONAC}

Art. 44. Os programas, projetos e ações culturais financiados com recursos do PRONAC deverão apresentar, obrigatoriamente, planos de distribuição de produtos deles decorrentes, obedecidos os seguintes critérios:

I- até dez por cento dos produtos com a finalidade de distribuição gratuita promocional pelo patrocinador; e

II - até dez por cento dos produtos, a critério do Ministério da Cultura, para distribuição gratuita pelo beneficiário.

Art. 45. Serão destinadas ao Ministério da Cultura, obrigatoriamente, para composição do seu acervo e de suas entidades vinculadas, pelo menos seis cópias do produto cultural ou do registro da ação realizada, resultantes de programas e projetos e ações culturais financiados pelo PRONAC.

Art. 46. Os produtos materiais e serviços resultantes de apoio do PRONAC serão de exibição, utilização e circulação públicas, não podendo ser destinados ou restritos a 
circuitos privados ou a coleções particulares, excetuados os casos previstos no Capítulo III deste Decreto.

Art. 47. É obrigatória a inserção da logomarca do Ministério da Cultura:

I - nos produtos materiais resultantes de programas, projetos e ações culturais realizados com recursos do PRONAC, bem como nas atividades relacionadas à sua difusão, divulgação, promoção, distribuição, incluindo placa da obra, durante sua execução, e placa permanente na edificação, sempre com visibilidade pelo menos igual à da marca do patrocinador majoritário; e

II - em peças promocionais e campanhas institucionais dos patrocinadores que façam referência a programas, projetos e ações culturais beneficiados com incentivos fiscais.

Parágrafo único. As logomarcas e os critérios de inserção serão estabelecidos pelo manual de identidade visual do Ministério da Cultura, aprovado pelo Ministro de Estado da Cultura, em consonância com o órgão responsável pela comunicação social no âmbito da Presidência da República, e publicado no Diário Oficial da União.

\section{CAPÍTULO VII}

\section{DA INTEGRAÇÃO DO PRONAC AO SISTEMA NACIONAL DE CULTURA}

Art. 48. Será estabelecido mecanismo de intercâmbio de informações com os Estados, Municípios e Distrito Federal, com o objetivo de se evitar duplicidade entre essas esferas e o PRONAC no apoio aos programas, projetos e ações executados nas respectivas unidades federadas.

$\S 1^{\circ}$ Não se considera duplicidade a agregação de recursos, nos diferentes níveis de governo, para cobertura financeira de programas, projetos e ações, desde que as importâncias autorizadas nas várias esferas não ultrapasse o seu valor total.

$\S 2^{\circ}$ A agregação de recursos a que se refere o $\S 1^{\circ}$ não exime o proponente da aprovação do projeto em cada nível de governo, nos termos das respectivas legislações.

$\S 3^{\circ}$ A captação de recursos em duplicidade ou a omissão de informação relativa ao recebimento de apoio financeiro de quaisquer outras fontes sujeitará o proponente às sanções e penalidades previstas na Lei $n^{\circ}$ 8.313, de 1991, e na legislação especial aplicável. 


\section{CAPÍTULO VIII}

\section{DAS DISPOSIÇÕES FINAIS E TRANSITÓRIAS}

Art. 49. O Ministério da Cultura concederá anualmente certificado de reconhecimento a investidores, beneficiários e entidades culturais que se destacarem pela contribuição à realização dos objetivos do PRONAC, na forma definida em ato do Ministério da Cultura.

Parágrafo único. Será facultada a utilização do certificado a que se refere o caput pelo seu detentor, para fins promocionais, consoante normas estabelecidas pelo Ministério da Cultura.

Art. 50. No prazo de até cento e vinte dias a contar da publicação deste Decreto, o Ministro de Estado da Cultura expedirá as instruções necessárias para seu cumprimento.

Art. 51. Os programas e projetos culturais aprovados com base no disposto nos Decretos $n^{\text {os }} 4.397$, de $1^{\circ}$ de outubro de 2002 , e 4.483 de 25 de novembro de 2002, poderão permanecer válidos até o último dia útil do exercício de 2006, observado o seguinte:

I- no caso de captação parcial de recursos, poderão os seus responsáveis apresentar prestação de contas final ou adequar-se às normas contidas neste Decreto; e

II - no caso de não captação de recursos, poderão ser definitivamente encerrados ou adequados às normas contidas neste Decreto.

Parágrafo único. Para fins de revalidação da autorização para captação de recursos, a adequação deverá ser solicitada ao Ministério da Cultura, que emitirá parecer à luz das disposições deste Decreto.

Art. 52. Os projetos e programas já aprovados com base no Decreto $n^{\circ} 1.494$, de 17 de maio de 1995, permanecerão válidos e vigentes, na forma da legislação aplicável à data de sua aprovação, até o final do prazo para a captação de recursos.

Parágrafo único. Decorrido o prazo de captação de recursos, os projetos poderão ser prorrogados, a critério do Ministério da Cultura.

Art. 53. O Ministério da Fazenda e o Ministério da Cultura disciplinarão, em ato conjunto, os procedimentos para a fiscalização dos recursos aportados pelos incentivadores em programas, projetos e ações culturais, com vistas à apuração do montante da renúncia fiscal de que trata este Decreto, nos termos do art. 36 da Lei $n^{\circ}$ 8.313, de 1991.

Art. 54. Este Decreto entra em vigor na data de sua publicação. 
Art. 55. Ficam revogados os Decretos $\mathrm{n}^{\text {os }} 1.494$, de 17 de maio de 1995, 2.585, de 12 de maio de 1998, 4.397, de $1^{\circ}$ de outubro de 2002, e 4.483, de 25 de novembro de 2002.

Brasília, 27 de abril de 2006; $185^{\circ}$ da Independência e $118^{\circ}$ da República.

LUIZ INÁCIO LULA DA SILVA

Guido Mantega

Paulo Bernardo Silva

Gilberto Gil 